U.S. Department of the Interior

U.S. Geological Survey

\title{
Summary of Hydrogeologic and Ground-Water-Quality Data and Hydrogeologic Framework at Selected Well Sites, Adams County, Pennsylvania
}

by Dennis J. Low and Diana L. Dugas

Water-Resources Investigations Report 99-4108

prepared in cooperation with the

Adams County Office of Planning and Development 


\title{
U.S. DEPARTMENT OF THE INTERIOR
}

\section{BRUCE BABBITT, Secretary}

\author{
U.S. GEOLOGICAL SURVEY
}

\author{
Charles G. Groat, Director
}

For additional information write to:

District Chief

U.S. Geological Survey

840 Market Street

Lemoyne, Pennsylvania 17043-1586
Copies of this report may be purchased from:

U.S. Geological Survey Branch of Information Services Box 25286

Denver, Colorado 80225-0286 


\section{CONTENTS}

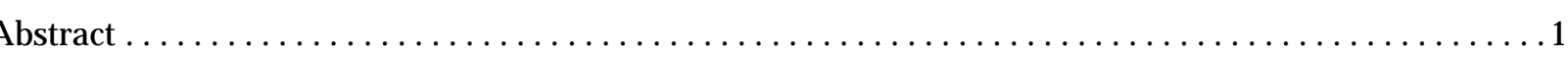

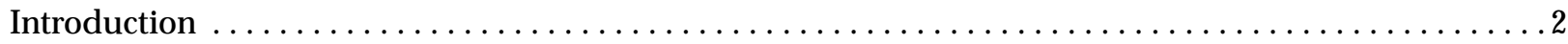

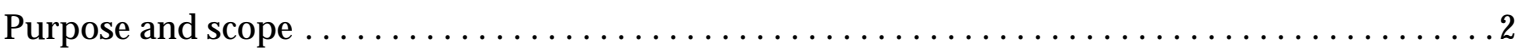

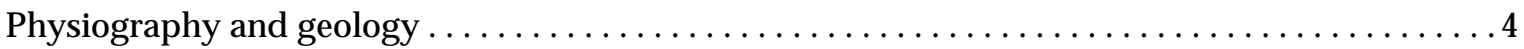

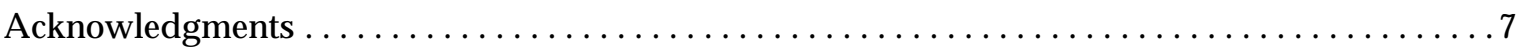

Summary of hydrogeologic and ground-water-quality data $\ldots \ldots \ldots \ldots \ldots \ldots \ldots \ldots \ldots \ldots \ldots$

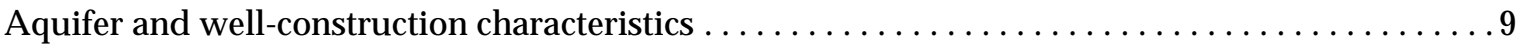

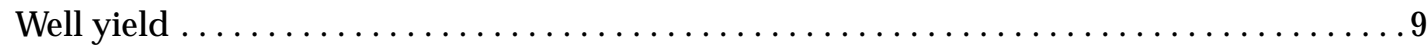

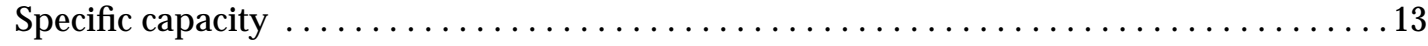

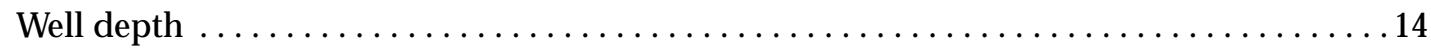

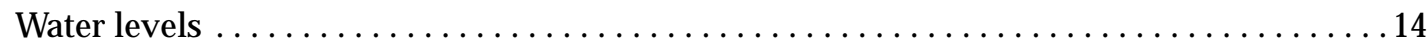

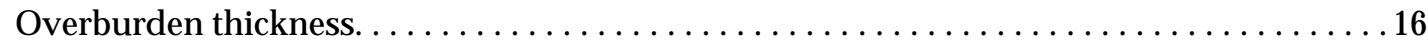

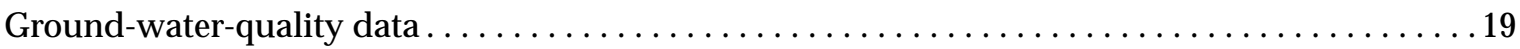

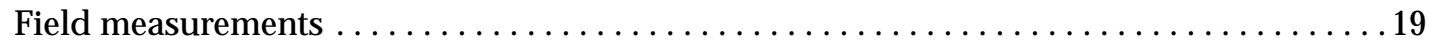

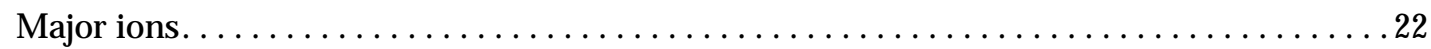

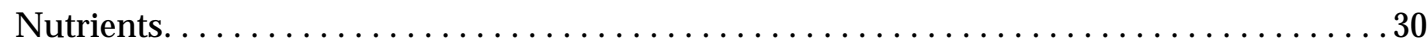

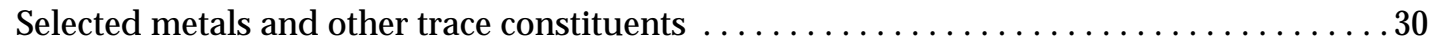

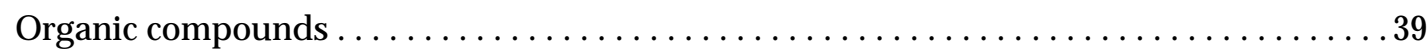

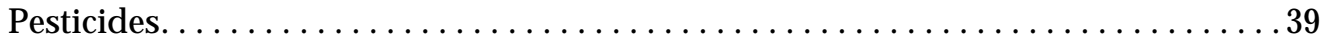

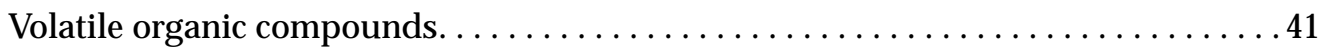

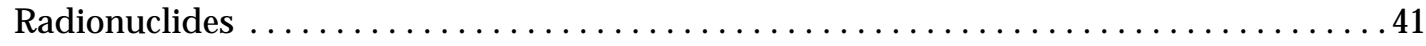

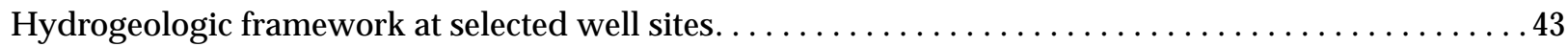

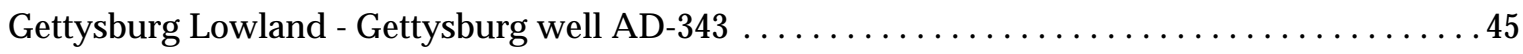

Conceptual ground-water flow system near well AD-343 .................. 45

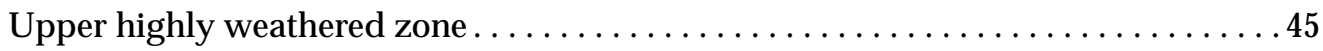

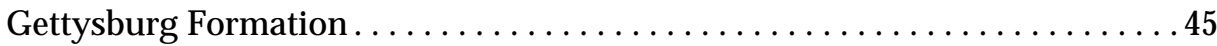

Diabase sill .................................. 45

Lower bedrock zone . . . . . . . . . . . . . . . . . . . . . . . . . . . . . . 49

Gettysburg Formation ............................. 49

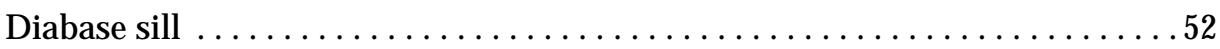

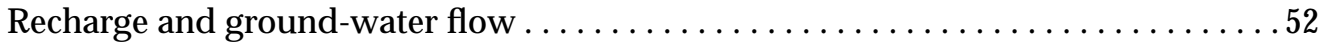

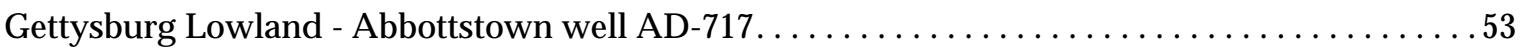

Conceptual ground-water flow system near well AD-717 $\ldots \ldots \ldots \ldots \ldots \ldots \ldots \ldots \ldots$

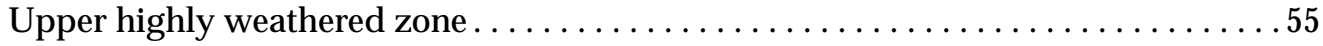

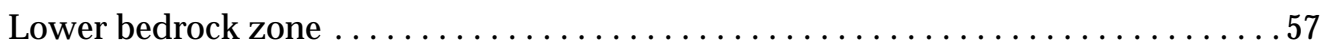

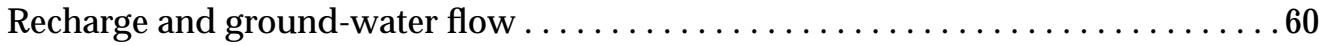

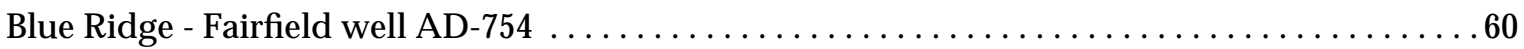

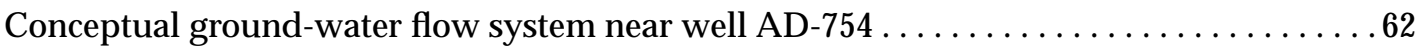

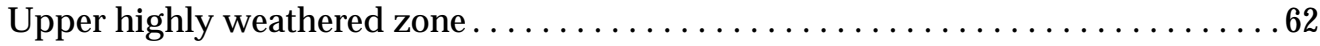

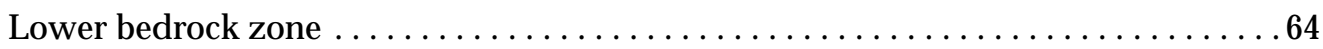

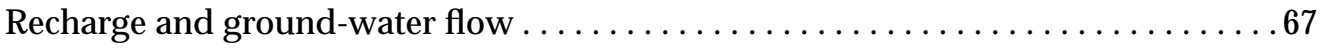




\section{CONTENTS-Continued}

Hydrogeologic framework at selected well sites-Continued

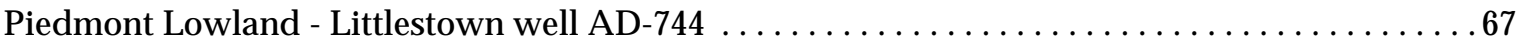

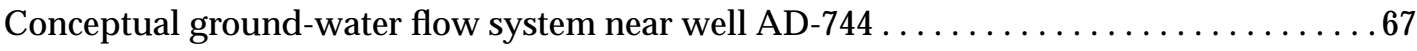

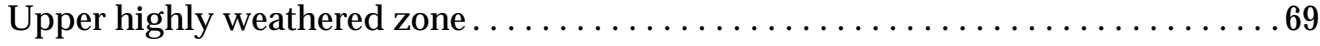

Lower bedrock zone $\ldots \ldots \ldots \ldots \ldots \ldots \ldots \ldots \ldots \ldots \ldots \ldots \ldots \ldots \ldots \ldots$

Recharge and ground-water flow $\ldots \ldots \ldots \ldots \ldots \ldots \ldots \ldots \ldots \ldots \ldots \ldots \ldots$

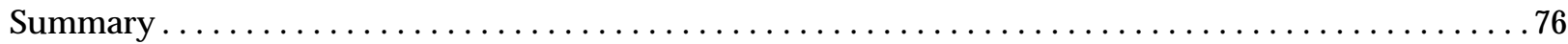

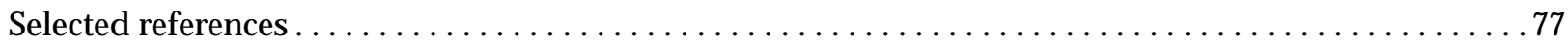

Appendix A. Pesticides sampled in ground water, Adams County. . . . . . . . . . . . . . 82

B. Volatile organic compounds sampled in ground water, Adams County . . . . . . . . . 85

\section{Figures}

Figures 1-9. Maps showing:

1. Location of Adams County, Pennsylvania . . . . . . . . . . . . 3

2. Location of four public-supply wells where the site-specific hydrogeologic framework was described, major hydrogeologic units, and major geologic formations within Adams County $\ldots \ldots \ldots \ldots \ldots \ldots \ldots$

3. Location of 2,389 wells in Adams County that were analyzed for this report. . . . 8

4. Location of domestic and nondomestic wells that are in the lower and upper 10 percent of reported yields for selected geologic formations . . . . 12

5. Location of domestic and nondomestic wells that are in the lower and upper 10 percent of reported specific capacities for selected geologic

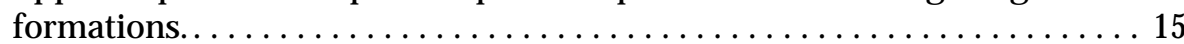

6. Location of wells in Adams County where ground water was sampled for analysis of nitrate, nitrite, or phosphorus. . . . . . . . . . 33

7. Location of wells in Adams County where ground water was sampled for analysis of minor and trace metals. . . . . . . . . . . . . 35

8. Location of wells in Adams County where ground water was sampled for

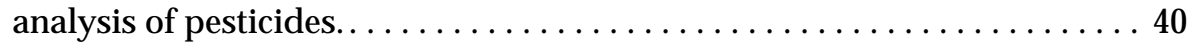

9. Location of hazardous waste sites and wells in Adams County that were sampled for analysis of volatile organic compounds not associated with hazardous waste site assessments or other such activities.. . . . . 42

10. Diagram showing the hydrogeologic framework of the upper highly weathered

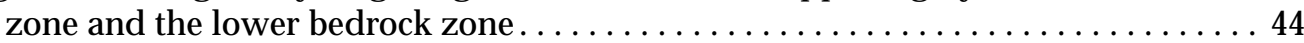

11. Map showing the location of well AD-343, selected other wells, Gettysburg Elevator and Hunterstown Road Superfund Sites, Pennsylvania led J.C. Cleaners Site, general geology, and water-level contours in the vicinity of Gettysburg . . . . . . 46

12. Schematic block diagram illustrating general geology and ground-water flow near

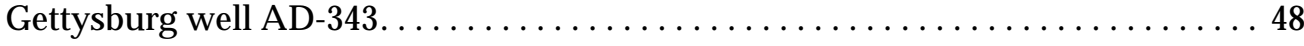

13. Borehole geophysical logs for borehole AD-343, November $3,1976 \ldots \ldots \ldots$ 


\section{Figures-Continued}

Figure 14. Map showing location of well AD-717 and selected other wells, general geology, and water-level contours in the vicinity of Abbottstown ................... 54

15. Schematic block diagram illustrating general geology and ground-water flow near Abbottstown well AD-717 ............................. 56

16. Borehole geophysical logs for borehole AD-716, September 18, 1997 . . . . . . . . 58

17. Map showing location of well AD-754, selected other wells, general geology, and water-level contours in the vicinity of Fairfield .................... 61

18. Schematic block diagram illustrating general geology and ground-water flow near

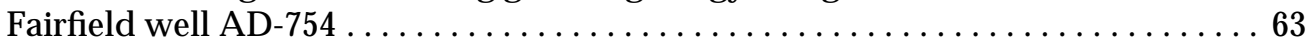

19. Borehole geophysical logs for borehole AD-750, September $25,1997 \ldots \ldots \ldots \ldots \ldots 65$

20. Map showing location of well AD-744, selected other wells, general geology, drainage basin, and water-level contours in the vicinity of Littlestown. . . . . . 68

21. Schematic block diagram illustrating general geology and ground-water flow near Littlestown well AD-744 .............................. 70

22-23. Borehole geophysical logs for:

22. Borehole AD-208, September 23, 1997. ..................... 72

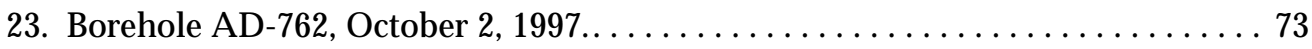




\section{Tables}

Table 1. Areas and number of wells by water use for the four major hydrogeologic units and associated geologic formations in Adams County, Pennsylvania . . . . . . . . . . 6

2. Reported well yield by hydrogeologic unit, geologic formation, and water use, Adams County. ...................................... 10

3. Specific capacity by hydrogeologic unit, geologic formation, and water use, Adams County..................................... 13

4. Well depth by hydrogeologic unit, geologic formation, and water use, Adams County...................................... 16

5. Water levels by hydrogeologic unit, geologic formation, and water use,

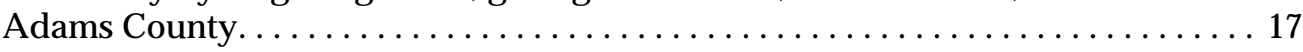

6. Summary statistics for water level by hydrogeologic unit and topographic setting, Adams County. ........................................ 17

7. Overburden thickness (depth to bedrock) by hydrogeologic unit, geologic

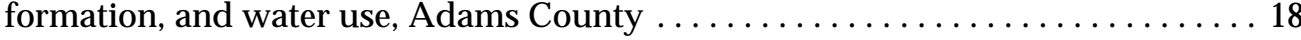

8. Summary statistics for overburden thickness (depth to bedrock) by hydrogeologic unit and topographic setting, Adams County .......................... 19

9. Field measurements of $\mathrm{pH}$ in ground water from Adams County by hydrogeologic

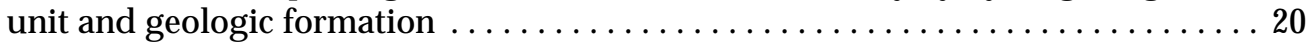

10. Field measurements of specific conductance in ground water from Adams County by hydrogeologic unit and geologic formation $\ldots \ldots \ldots \ldots \ldots \ldots \ldots \ldots \ldots \ldots \ldots$

11. Field measurements of dissolved oxygen in ground water from Adams County by hydrogeologic unit and geologic formation $\ldots \ldots \ldots \ldots \ldots \ldots \ldots \ldots \ldots \ldots \ldots \ldots 22$

12. Field measurements of alkalinity in ground water from Adams County by hydrogeologic unit and geologic formation $\ldots \ldots \ldots \ldots \ldots \ldots \ldots \ldots \ldots \ldots \ldots \ldots$

13. Field measurements of hardness in ground water from Adams County by hydrogeologic unit and geologic formation $\ldots \ldots \ldots \ldots \ldots \ldots \ldots \ldots \ldots \ldots \ldots \ldots \ldots \ldots$

14. Total dissolved solids in ground water from Adams County by hydrogeologic unit

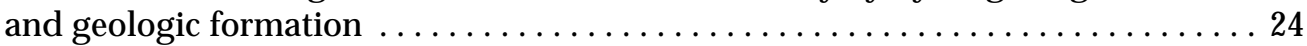

15. Dissolved calcium and magnesium in ground water from Adams County by

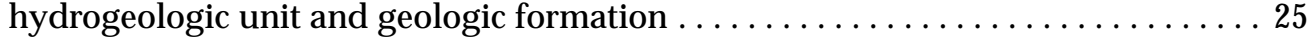

16. Dissolved sodium and potassium in ground water from Adams County by

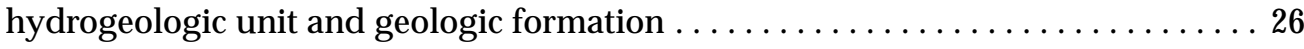

17. Dissolved chloride in ground water from Adams County by hydrogeologic unit and

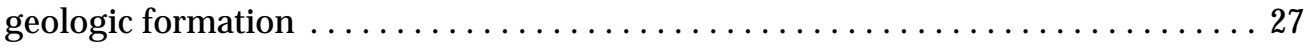

18. Dissolved sulfate in ground water from Adams County by hydrogeologic unit and

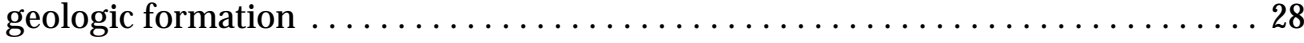

19. Dissolved fluoride and silica in ground water from Adams County by

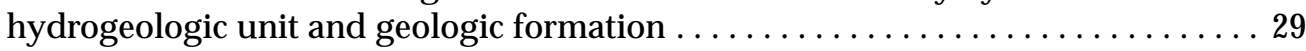

20. Dissolved nitrate and nitrite (as N) in ground water from Adams County by hydrogeologic unit and geologic formation $\ldots \ldots \ldots \ldots \ldots \ldots \ldots \ldots \ldots \ldots \ldots \ldots \ldots$

21. Phosphorus as total, dissolved, and orthophosphate in ground water from Adams County by hydrogeologic unit and geologic formation $\ldots \ldots \ldots \ldots \ldots \ldots \ldots \ldots \ldots$ 
Tables-Continued

Page

Table 22. Dissolved aluminum in ground water from Adams County by hydrogeologic unit

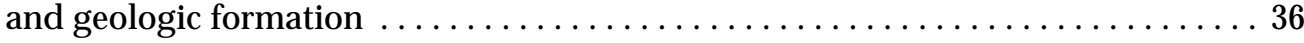

23. Dissolved iron in ground water from Adams County by hydrogeologic unit and

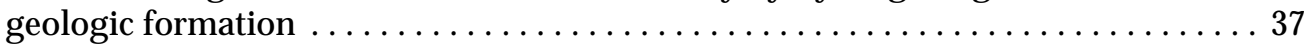

24. Dissolved lead in ground water from Adams County by hydrogeologic unit and

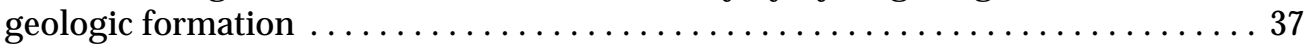

25. Dissolved manganese in ground water from Adams County by hydrogeologic unit

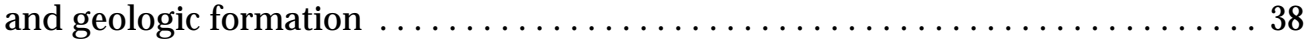

26. Dissolved zinc in ground water from Adams County by hydrogeologic unit and

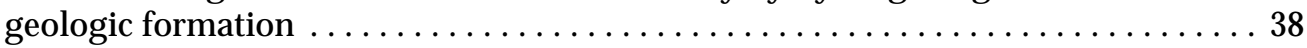

27. Pesticides detected in ground water, Adams County ....................... 39

28. Volatile organic compounds detected in ground water, Adams County ........... 41

29. Record of selected wells in the vicinity of Gettysburg $\ldots \ldots \ldots \ldots \ldots \ldots \ldots \ldots \ldots$

30. Summary of brine-tracing measurements for wells AD-591, AD-598, AD-629, and AD-652 in the vicinity of Gettysburg . . . . . . . . . . . . . . . . . . 51

31. Hydraulic conductivity and transmissivity from single-well aquifer tests or specificcapacity tests in the Gettysburg Formation throughout Pennsylvania......... 51

32. Summary of hydraulic properties from single- and multiple-well aquifer tests for the Gettysburg Formation in the vicinity of Gettysburg. . . . . . . . . . . . 51

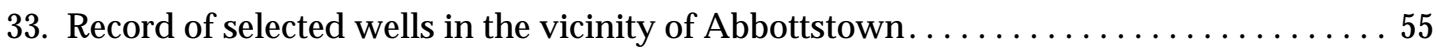

34. Summary of heatpulse-flowmeter measurements for Abbottstown well AD-716 . . . . 59

35. Summary of hydraulic properties from the 72-hour multiple-well aquifer test of Abbottstown well AD-717 ..................................... 59

36. Hydraulic conductivity and transmissivity from single-well aquifer tests or specificcapacity tests in the New Oxford Formation throughout Pennsylvania . . . . . . . 59

37. Summary of water-level measurements of a 72-hour aquifer test for Abbottstown

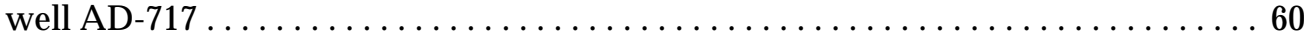

38. Record of selected wells in the vicinity of Fairfield $\ldots \ldots \ldots \ldots \ldots \ldots \ldots \ldots \ldots \ldots \ldots \ldots \ldots \ldots \ldots \ldots$

39. Summary of heatpulse-flowmeter measurements for Fairfield well AD-750 . . . . . 66

40. Summary of hydraulic properties from the 48-hour multiple-well aquifer tests of Fairfield wells AD-751 and AD-754 ............................. 66

41. Summary of hydraulic properties from the 48.5- and 49-hour multiple-well aquifer tests of Fairfield wells AD-736 and AD-750 . . . . . . . . . . . . . . . 66

42. Record of selected wells in the vicinity of Littlestown $\ldots \ldots \ldots \ldots \ldots \ldots \ldots \ldots$

43. Summary of heatpulse-flowmeter measurements for Littlestown well AD-208 . . . . . 71

44. Summary of heatpulse-flowmeter measurements for Littlestown well AD-762 . . . . . 74

45. Hydraulic conductivity and transmissivity from single-well aquifer or specificcapacity tests in the Conestoga Formation throughout Pennsylvania ......... 74 


\section{CONVERSION FACTORS, VERTICAL DATUM, AND ABBREVIATIONS}

\begin{tabular}{|c|c|c|}
\hline \multicolumn{3}{|c|}{ Length } \\
\hline inch (in.) & 25.4 & millimeter \\
\hline foot $(\mathrm{ft})$ & 0.3048 & meter \\
\hline mile (mi) & 1.609 & kilometer \\
\hline \multirow{3}{*}{ square mile $\left(\mathrm{mi}^{2}\right)$} & Area & \\
\hline & 2.59 & square kilometer \\
\hline & Flow & \\
\hline gallons per minute (gal/min) & 0.06308 & liter per second \\
\hline million gallons per day $(\mathrm{Mgal} / \mathrm{d})$ & 43.81 & liter per second \\
\hline $\begin{array}{l}\text { gallon per day per square mile } \\
{\left[(\mathrm{gal} / \mathrm{d}) / \mathrm{mi}^{2}\right]}\end{array}$ & 0.001461 & $\begin{array}{l}\text { cubic meter per day per } \\
\text { square kilometer }\end{array}$ \\
\hline
\end{tabular}

Specific capacity

gallon per minute per foot

0.2070

liter per second per meter $[(\mathrm{gal} / \mathrm{min}) / \mathrm{ft}]$

$\underline{\text { Hydraulic properties }}$

feet per day $(\mathrm{ft} / \mathrm{d})$

$0.0931 \quad$ meter squared per day

feet squared per day $\left(\mathrm{ft}^{2} / \mathrm{d}\right)$

Vertical datum: In this report, "sea level" refers to the National Geodetic Vertical Datum of 1929-a geodetic datum derived from a general adjustment of the first-order level nets of the United States and Canada, formerly called Sea Level Datum of 1929.

Abbreviated water-quality units used in report: $\mathrm{mg} / \mathrm{L}$, milligrams per liter $\mu \mathrm{g} / \mathrm{L}$, micrograms per liter $\mathrm{pCi} / \mathrm{L}$, picocuries per liter $\mu \mathrm{S} / \mathrm{cm}$, microsiemens per centimeter at 25 degrees Celsius 


\title{
Summary of Hydrogeologic and Ground-Water-Quality Data and Hydrogeologic Framework at Selected Well Sites, Adams County, Pennsylvania
}

\author{
by Dennis J. Low and Diana L. Dugas
}

\section{Abstract}

Rapid population growth in Adams County has increased the demand for ground water and led Adams County planning officials to undertake an effort to evaluate the capabilities of existing community water systems to meet future, projected growth and to begin wellhead-protection programs for public-supply wells. As part of this effort, this report summarizes ground-water data on a countywide scale and provides hydrogeologic information needed to delineate wellheadprotection areas in three hydrogeologic units (Gettysburg Lowland, Blue Ridge, and Piedmont Lowland).

Reported yields, specific capacities, well depths, and reported overburden thickness can vary by hydrogeologic unit, geologic formation, water use (domestic and nondomestic), and topographic setting. The reported yields of domestic wells drilled in the Gettysburg Lowland (median reported yield of 10 gallons per minute) are significantly greater than the reported yields from the Blue Ridge, Piedmont Lowland, and Piedmont Upland (median reported yields of 7.0, 8.0, and 7.0 gallons per minute, respectively). Reported yields of domestic wells completed in the diabase and the New Oxford Formation of the Gettysburg Lowland, and in the metarhyolite and metabasalt of the Blue Ridge, are significantly lower than reported yields of wells completed in the Gettysburg Formation. For nondomestic wells, reported yields from the Conestoga Formation of the Piedmont Lowland are significantly greater than in the diabase. Reported yields of nondomestic wells drilled in the Gettysburg, New Oxford, and Conestoga Formations, and the metarhyolite are significantly greater than those for domestic wells drilled in the respective geologic formations. Specific capacities of nondomestic wells in the Conestoga and Gettysburg Formations are significantly greater than their domestic counterparts. Specific capacities of nondomestic wells in the Conestoga Formation are significantly greater than the specific capacities of nondomestic wells in the metarhyolite, diabase, and Gettysburg and New Oxford Formations. Well depths do not vary considerably by hydrogeologic unit; instead, the greatest variability is by water use. Nondomestic wells drilled in the metarhyolite, Kinzers, Conestoga, Gettysburg, and New Oxford Formations are completed at significantly greater depths than their domestic counterparts. The reported thickness of overburden varies significantly by geologic formation and water use, but not by topographic setting. The median overburden thickness of the Blue Ridge (35 feet) is greater than in any other hydrologic unit.

Except where adversely affected by human activities, ground water in Adams County is suitable for most purposes. Calcium and magnesium are the dominant cations, and bicarbonate is the dominant anion. In general, the $\mathrm{pH}$ and hardness of ground water is lower in areas that are underlain by crystalline rocks (Blue Ridge and Piedmont Upland) than in areas underlain by sedimentary rocks, especially where limestone or dolomite is dominant (Piedmont Lowland). Dissolved nitrate (as N) and dissolved nitrite (as N) concentrations in the water from 9 of 69 wells and 3 of 80 wells sampled exceeded the U.S. Environmental Protection Agency (USEPA) maximum contaminant levels (MCL) of 10 and $1.0 \mathrm{mg} / \mathrm{L}$ (milligrams per liter), respectively. Sulfate concentrations greater than the proposed USEPA MCL of $500 \mathrm{mg} / \mathrm{L}$ were reported from the water in 3 of 110 wells sampled. Iron concentrations in the water from 13 of 67 wells sampled and manganese in the water from 9 of 64 wells sampled exceeded the USEPA secondary maximum contaminant level (SMCL) of 300 and $50 \mu \mathrm{g} / \mathrm{L}$ (micrograms per liter), respectively. Aluminum concentrations in the water from 16 of 22 wells sampled exceeded the lower USEPA SMCL threshold of $50 \mu \mathrm{g} / \mathrm{L}$. Pesticides were detected in the water from seven wells but at concentrations that did not exceed USEPA MCL's. Most volatile organic compounds detected in the ground water were confined to USEPA Superfund sites or the immediate area around the sites. 
The hydrogeologic framework in the vicinity of four public-supply well fields (Gettysburg, Abbottstown, Fairfield, and Littlestown) consists of two zones-an upper zone and a lower zone. In general, the upper zone is thin (5 to 60 feet or more) and dominated by saturated regolith and deeply weathered bedrock. The upper zone is bounded at the top by the water table and below by bedrock in which secondary porosity and permeability are considerably lower. Ground water is generally unconfined, and recharge rates are rapid. Ground-water flow is influenced more strongly by the topography of the ground surface and bedrock surface than by geologic structure. The lower zone is relatively thick (400 to 1,000 feet) and consists of slightly weathered to highly competent bedrock. Ground-water flow paths in the lower zone are generally greater and recharge rates are longer than in the upper zone; confined conditions are common, especially at depth.

\section{INTRODUCTION}

Adams County has experienced substantial growth in recent years because of its rural character, low housing costs, and proximity to major metropolitan areas. Adams County is located in southcentral Pennsylvania (fig. 1) within commuting distance from Harrisburg, York, and the greater Baltimore area. The county's population of 68,300 in 1980 increased to an estimated 91,000 by 1997 (Deborah Slawson, Adams County Office of Planning and Development, oral commun., 1999) and is expected to increase 15 percent each decade for the foreseeable future. In a recent analysis of the county's existing community water systems, county planners discovered many systems were inadequate for the expected population growth; new water systems will need to be built or existing systems will need to be expanded (Norman Day Associates, 1991).

Recognizing the need for additional information on water resources, the Adams County Office of Planning and Development initiated a Water-Supply/Wellhead-Protection study. The objectives of that study are to (1) evaluate existing water systems, (2) identify and evaluate the current and potential future use of aquifers and surface-water sources, (3) determine measures to protect source water from contamination, and (4) evaluate wellheadprotection strategies at one well in four different hydrogeologic settings. The U.S. Geological Survey
(USGS) cooperated in the study and USGS was able to summarize available ground-water data on a countywide scale, provide key hydrogeologic information needed to delineate wellheadprotection areas in the vicinity of four publicsupply wells, and compile a digital geologic map (ARC/INFO dataset) of Adams County.

\section{Purpose and Scope}

This report presents the results of two groundwater investigations conducted by USGS in cooperation with the Adams County Office of Planning and Development in support of their Water-Supply/Wellhead-Protection planning efforts. The first part of the report summarizes available hydrogeologic and ground-water chemical data on a countywide basis. The second part of this report describes the hydrogeologic framework in the vicinity of four current or potential public-supply wells in three different hydrogeologic settings. A third effort, to compile a digital geologic map of Adams County, was previously completed (Dugas and Weisbeker, 1997) and is available from the USGS Pennsylvania District world-wide web site (http:/ / pa.water.usgs.gov) under Digital Spatial Data.

Hydrogeologic and ground-water-quality data were summarized on a countywide basis from information available in computerized databases. Aquifer and well-construction characteristics were updated with data from about 1,700 wells not used in previous studies (Taylor and Royer, 1981; Wood, 1980) and a geographic information system (GIS) was used to identify any areas of greater-thanaverage potential for ground-water development. Ground-water-quality data were summarized to provide a baseline data set against which future water-quality changes can be measured and to show locations in Adams County where groundwater samples have been collected.

Investigations of the hydrogeologic framework in the vicinity of four current or potential publicsupply wells were conducted to develop a conceptual diagram of ground-water flow at each site within the Gettysburg Lowland, Blue Ridge, and Piedmont Lowland. This frame-work would then help guide the delineations of wellheadprotection areas for wells within the same hydrogeologic unit. The following sites were selected by the Adams County Office of Planning and Development: the Gettysburg and Abbotts- 


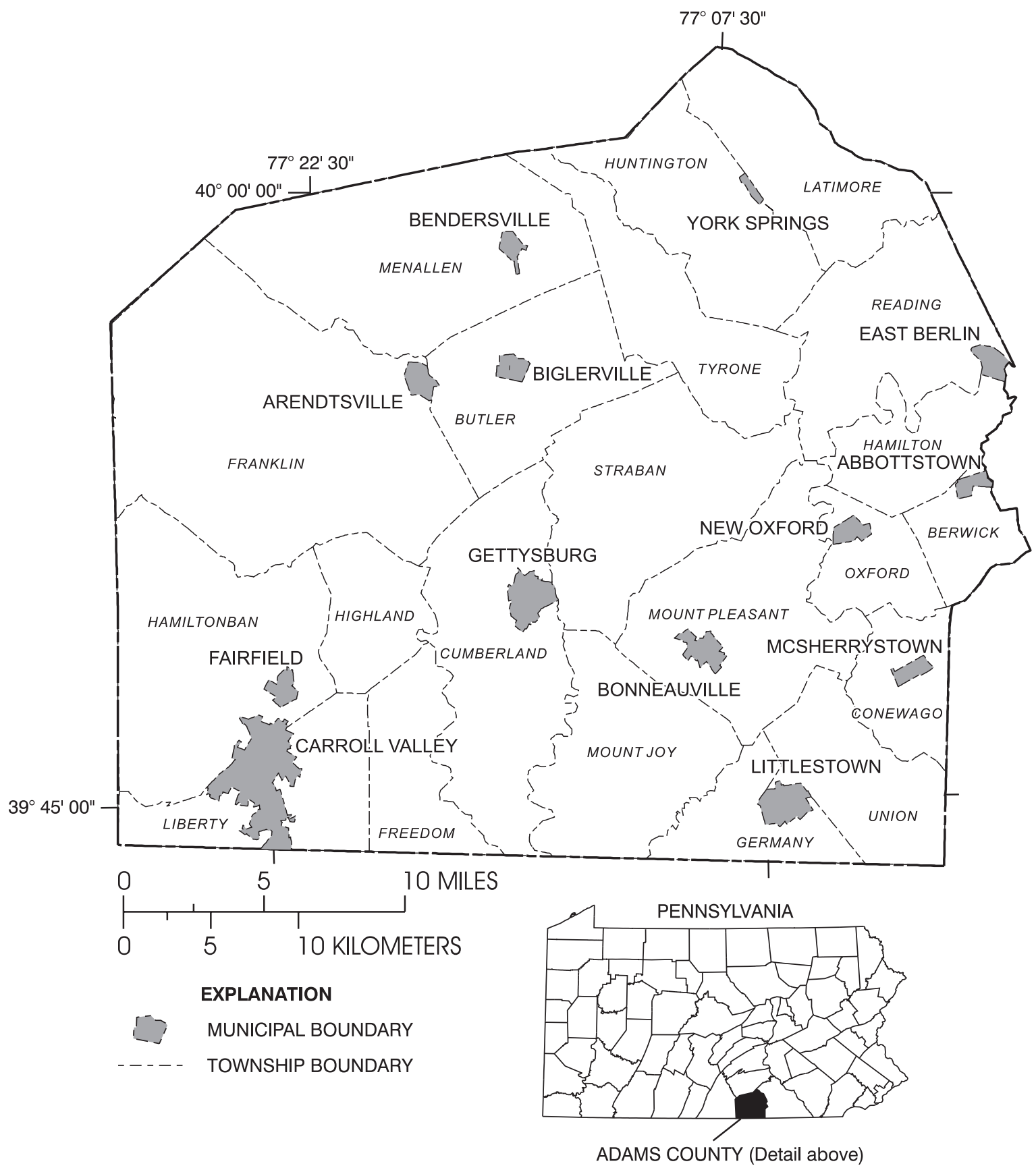

Figure 1. Location of Adams County, Pennsylvania. 
town public-supply wells in the Gettysburg Lowland hydrogeologic unit, the Fairfield publicsupply well in the Blue Ridge unit, and the Littlestown public-supply well in the Piedmont Lowland unit (fig. 2). Due to the scarcity of publicsupply wells and available well or aquifer information, a suitable study area could not be located in the Piedmont Upland hydrogeologic unit, so that unit is not represented. The scope of the individual investigations included water-table mapping, borehole geophysical logging, and analysis of aquifer-test data and hydrogeologic information from previous studies.

\section{Physiography and Geology}

Adams County has an area of $522 \mathrm{mi}^{2}$ characterized by broad, rolling hills and valleys in its eastern and central parts to pronounced ridges and deep valleys along its western margin. The county can be divided into two major watersheds-Susquehanna and Potomac. The Conewago River and its tributaries drain northeastern Adams County, and runoff flows into the Susquehanna River. The Monocacy River and its tributaries drain the southwestern part of the county, and runoff flows into the Potomac River.

The eastern three-quarters of Adams County is within the Piedmont Upland, Piedmont Lowland, and Gettysburg-Newark Lowland Sections of the Piedmont Physiographic Province and the western one-quarter is within the Blue Ridge Physiographic Province. The Valley and Ridge Physiographic Province extends into the northwestern corner of the county, but its size $\left(0.2 \mathrm{mi}^{2}\right)$ is insignificant. These major physiogra-phic divisions are distinctive because of the different rock types that underlie each. Rock type, in turn, is a major factor controlling ground-water movement and chemical quality. Thus, the Blue Ridge Physiographic Province and the Piedmont Upland, Piedmont Lowland, and Gettysburg-Newark Lowland Sections of the Piedmont Physiographic Province represent the four major hydrogeologic units (in general, areas with similar geologic history, lithology, and hydrologic properties) within Adams County (fig. 2). The geologic formations within each of the four major hydrogeologic units are described in table 1.

The Gettysburg Lowland hydrogeologic unit (fig. 2) covers the largest area, more than half of the county, and is underlain by Triassic-Jurassic age sedimentary (shale, siltstone, sandstone, minor limestone, and conglomerate) and igneous rocks (diabase). Rolling lowlands and isolated hills and highlands are representative of the topography in this section (Berg and others, 1989). The principal geologic formations that form the Gettysburg Lowland are the Gettysburg Formation, New Oxford Formation, and diabase (Stose, 1932; Taylor and Royer, 1981).

The diabase underlies about $55 \mathrm{mi}^{2}$ of Adams County. It is dark gray to black, medium- to coarsegrained in the center of large intrusions and fine grained at contacts and in narrow dikes. The major minerals labradorite and augite are present in about equal proportions, and ilmenite, quartz, and apatite are accessory minerals (Wood and Johnston, 1964, p. 12).

The Gettysburg Formation, which underlies about $224 \mathrm{mi}^{2}$ of Adams County, is in general a soft, reddish-brown shale containing interbeds of siltstone and sandstone. In their work on the Gettysburg Formation, Stose (1932) and Stose and Bascom (1929) identified several members or lithologic units distinctly different from the dominant red-brown shale and sandstones. The uppermost lithologic unit is a limestone conglomerate and, near South Mountain, a quartzose fanglomerate. A middle member, named the Heidlersburg, consists of a gray to white sandstone and conglomerate with interbeds of red shale and sandstone and some green, gray, and black shale. A basal member, called the Conewago Conglomerate Member, consists of numerous beds of hard, pebbly siliceous sandstone and poorly sorted sandstone and quartz conglomerate. Near the contact with intrusive diabase, the shale is altered to dark-red-purple to purple argillite.

The New Oxford Formation underlies about $63 \mathrm{mi}^{2}$ of the county and consists of a complex, interbedded sequence of sandstones, siltstones, shales, and conglomerates. Bedding is lenticular, and individual beds grade rapidly into rocks of different textures. The siltstones and shales, which are present throughout the formation, are generally red, but other colors are not uncommon; many shales are micaceous and calcareous (Johnston, 1966, p. 10). The quartzose conglomerates are most common in the lower two-thirds of the formation. Wood and Johnston (1964, p. 10) noted the presence of a basal limestone conglomerate near the contact with rocks of Paleozoic age. 


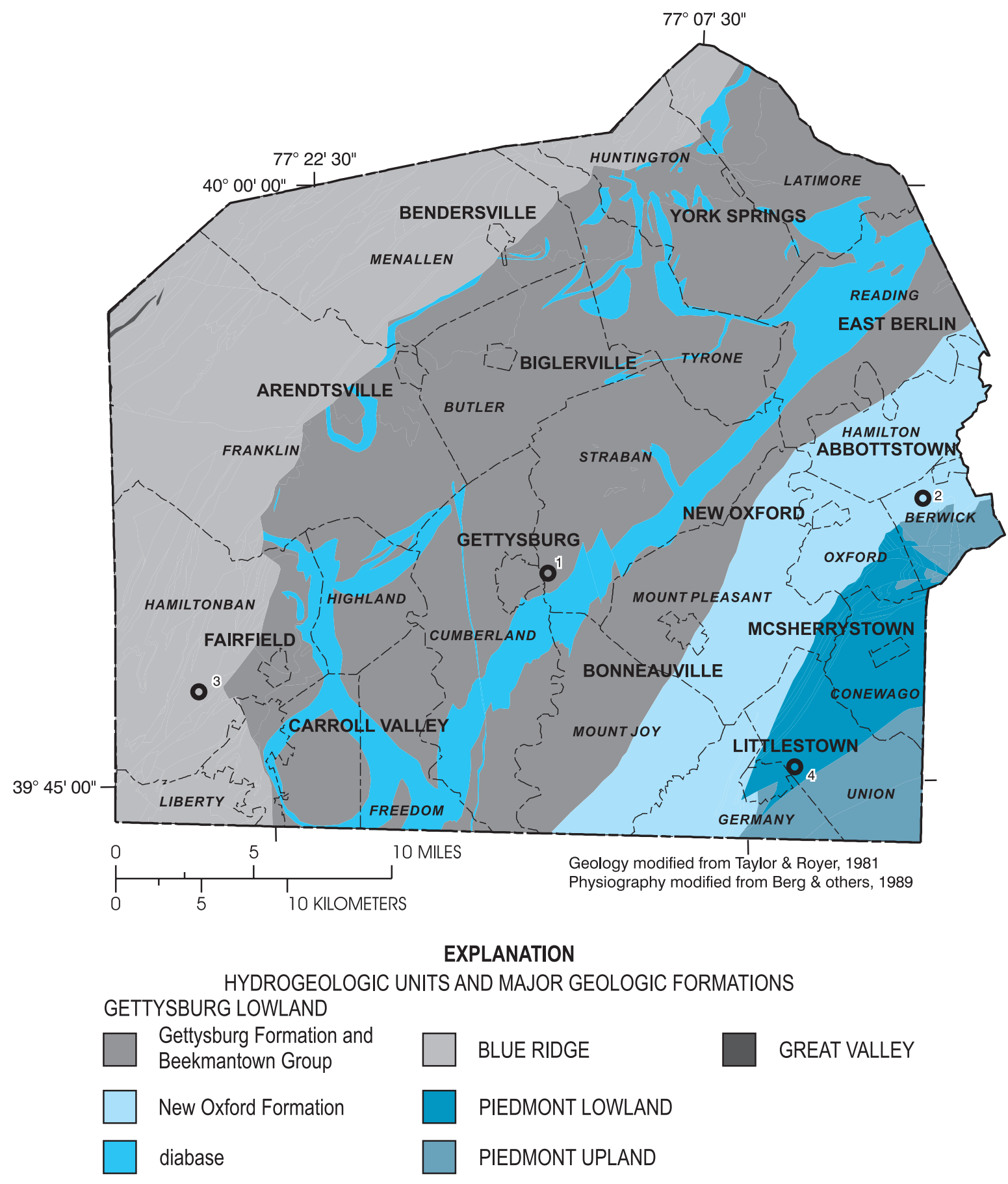
$\mathbf{0}_{4}$ LOCATION OF PUBLIC SUPPLY WELL FIELD
1 Gettysburg well AD-343
2 Abbotstown well AD-717
3 Fairfield well AD-754
4 Littlestown well AD-744

Figure 2. Location of four public-supply wells where the site-specific hydrogeologic framework was described, major hydrogeologic units, and major geologic formations within Adams County, Pennsylvania. 
Table 1. Areas and number of wells by water use for the four major hydrogeologic units and associated geologic formations in Adams County, Pennsylvania

[Geologic formations are formal and informal names according to Pennsylvania Topographic and Geologic Survey usage; nondomestic water use includes commercial, industrial, institutional, monitor, irrigation, emergency fire, stock, cooling, and public-supply uses]

\begin{tabular}{lrrr}
\hline Hydrogeologic unit and & \multirow{2}{*}{$\begin{array}{c}\text { Area } \\
\text { geologic formation }\end{array}$} & \multicolumn{2}{c}{ Water use } \\
\cline { 3 - 4 } (with abbreviation) & miles) & $\begin{array}{c}\text { Domestic } \\
\text { wells }\end{array}$ & $\begin{array}{c}\text { Nondomestic } \\
\text { wells }\end{array}$ \\
\hline Gettysburg Lowland Hydrogeologic Unit & 347.1 & 1,328 & 455 \\
Diabase (Trd) & 55.5 & 234 & 68 \\
Gettysburg Formation (Trg) & 223.9 & 740 & 290 \\
New Oxford Formation (Trn) & 63.4 & 353 & 96 \\
Beekmantown Group (Ob) & 4.3 & 1 & 1 \\
\hline Blue Ridge Hydrogeologic Unit & 134.9 & 319 & 39 \\
Antietam Formation (Ca) & 1.3 & 0 & 0 \\
Harpers Formation (Ch) & 15.9 & 15 & 6 \\
Weverton Formation (Cw) & 16.5 & 6 & 1 \\
Loudoun Formation (Cld) & 2.3 & 0 & 0 \\
Metabasalt (mb) & 24.3 & 81 & 1 \\
Metarhyolite (mr) & 69.8 & 209 & 30 \\
Greenstone Schist (vs) & 4.8 & 23 & 1 \\
\hline Piedmont Lowland Hydrogeologic Unit & 22.4 & 107 & 38 \\
Conestoga Formation (OCc) & 14.1 & 67 & 26 \\
Ledger Formation (Cl) & 1.7 & 10 & 1 \\
Kinzers Formation (Ck) & 5.4 & 24 & 7 \\
Vintage Formation (Cv) & 1.2 & 6 & 4 \\
\hline Piedmont Upland Hydrogeologic Unit & 17.4 & 100 & 3 \\
Antietam Formation (Ca) & .8 & 4 & 1 \\
Harpers Formation (Ch) & 8.8 & 49 & 2 \\
Chickies Formation (Cch) & 1.6 & 5 & 0 \\
Marburg Schist (Xwm) & 4.1 & 22 & 0 \\
Metabasalt (mb) & 2.1 & 20 & 0 \\
\hline & & & \\
\hline
\end{tabular}


The Piedmont Lowland underlies about $22 \mathrm{mi}^{2}$ in the southeastern part of the county (fig. 2 and table 1). The Conestoga, Ledger, Kinzers, and Vintage Formations are Cambrian to Ordovician in age; limestone and dolomite are dominant but are commonly interbedded with some shale and marble.

To the north and south of the Piedmont Lowland are two small parts of the Piedmont Upland (fig. 2) that together make up about $17 \mathrm{mi}^{2}$ of Adams County. The Harpers Formation, a graywacke siltstone and graywacke with a prominent interval of quartzite, is the most extensive geologic formation present (table 1). The Marburg Schist, which contains beds of quartzite and conglomerate, and the metabasalt comprise most of the remaining geologic units. These metamorphic and siliciclastic rocks are fairly resistant to erosion and form broad, gently rolling hills and valleys (Berg and others, 1989).

The Blue Ridge (fig. 2) underlies about $135 \mathrm{mi}^{2}$ of the western part of Adams County. Most of this area is underlain by Precambrian age metavolcanic rocks (metabasalt, metarhyolite, and greenstone schist) collectively called the Catoctin Formation; smaller areas are underlain by quartzite, phyllite, graywacke, or dolomite. The metarhyolite is the most extensive unit of the Catoctin Formation, which represents more than one-half of the rocks currently exposed at South Mountain in Adams County. The metabasalt and greenstone schist are present mainly as thin linear belts within the metarhyolite except near the Maryland-

Pennsylvania border, where the metabasalt is more extensive. Pronounced ridges and deep valleys are typical of these erosion resistant rocks (Taylor and Royer, 1981).

\section{Acknowledgments}

The authors acknowledge the cooperation of personnel of the Adams County Office of Planning and Development for their assistance with field work and with the planning and review of this report. The authors acknowledge the cooperation of the well owners and public-water suppliers for permitting access to their wells. The authors also thank the members of the report-preparation team (Douglas Chichester, Patricia Lietman, Dennis Risser, Curtis Schreffler, Robert Thaeler, Kim Otto, and Charles Wood) and Scott Hoffman, Naomi Weisbeker, and James Bubb for their expertise and assistance in the preparation of the map illustrations.

\section{SUMMARY OF HYDROGEOLOGIC AND GROUND-WATER-QUALITY DATA}

Aquifer and well-construction data used in this report were obtained from two computerized databases-the USGS Ground-Water Site Inventory (GWSI) database (650 wells) and the Pennsylvania Topographic and Geologic Survey's (T\&GS) Water-Well Inventory (WWI) database $(1,739$ wells); the locations of these 2,389 wells are shown in figure 3 . The data available from both databases are similar and may contain information on water use, reported yield, specific capacity, well depth, depth to bedrock, length of casing, static water level, and principal aquifer. The main difference between the two databases is the precision with which the wells are located. Wells in the GWSI database have been visited in the field, and their locations have been verified by USGS personnel who have worked in Adams County. Locations of wells in the WWI database are not visited by state personnel, and their locations are largely dependant on the information supplied by the water well driller. The GWSI database also contains a large amount of field water-quality information-such as $\mathrm{pH}$, specific conductance, temperature, and hardness - collected when the water well was inventoried. These water-quality data were supplemented by information available from two other computerized databases-the Water Data Storage and Retrieval System (WATSTORE) and STORET. WATSTORE and STORET are national water-quality data storage and retrieval systems. WATSTORE is operated and maintained by the USGS; STORET is operated and maintained by the U.S. Environmental Protection Agency (USEPA). The data stored in WATSTORE were derived from USGS water-resource investigations. Data stored in STORET may include USGS, USEPA, state, county, and other municipal water-quality data that were collected for a variety of reasons such as water-resource investigations, water-quality enforcement actions or monitoring, and permitting of new or existing water sources.

Multiple comparison tests (Tukey's nonparametric unbalanced design, alpha $=0.05$ ) on the grouped data (well yield, specific capacity, well depth, depth-to-water, and overburden thickness) were performed, if the sample population contained a minimum of 10 observations, to determine whether statistically significant differences in hydraulic or well-construction characteristics exist among the hydrogeologic units 


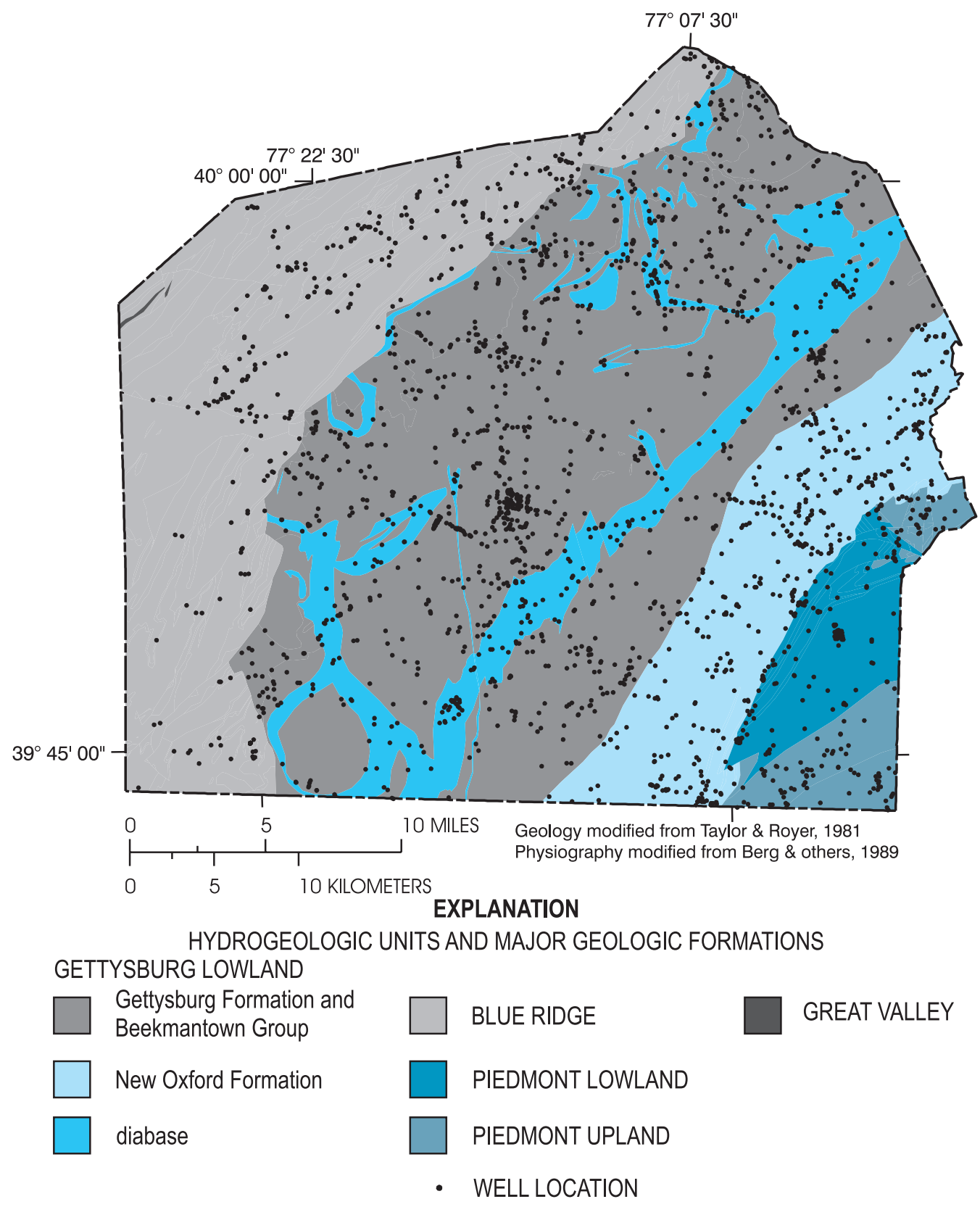

Figure 3. Location of 2,389 wells in Adams County, Pennsylvania, that were analyzed for this report. 
or geologic formations. Nonparametric (distribution free) statistical tests were used because the data are not normally distributed. The data are discussed in the following sections and summarized by reporting the minimum, medium, maximum, 10th and 90th percentiles for each hydrogeologic unit or geologic formation according to water use.

\section{Aquifer and Well-Construction Characteristics}

The purpose for which a well is drilled can have a significant effect on reported yield, specific capacity, and construction characteristics (well depth, casing diameter, casing length, and location); thus, the analyses of aquifer and welldepth characteristics were performed on two population sets-nondomestic wells and domestic wells. Nondomestic wells, those used for industrial, institutional, irrigation, emergency, and public-water supply, generally have greater reported yields than domestic wells. These socalled "high-demand" wells are generally drilled deeper and have a greater chance of penetrating more water-bearing zones than domestic wells. The boreholes of high-demand wells also are generally much larger than domestic wells (generally $10 \mathrm{in.}$ in diameter or greater versus the 6 in. or smaller in diameter of most domestic wells). A larger borehole will increase the ability of penetrated water-bearing zones to more efficiently transmit water to the well, and larger casing diameters permit the installation of larger pumps. In addition, high-demand wells commonly are located with knowledge of the general hydraulic properties of the underlying rock and are extensively developed when drilled. The yields of high-demand wells, therefore, generally represent the maximum a geologic formation can yield.

Wells constructed for domestic supply generally are located for convenience-close to the house in which the water will be used. Domestic wells commonly are completed after meeting minimal needs (typically $5 \mathrm{gal} / \mathrm{min}$ ) and generally are developed for 1 hour or less. Domestic wells will generally represent a lower, albeit a more dispersed, yield potential of a geologic formation than will high-demand, nondomestic wells.
Another group of wells, consisting of those used for commercial, stock, or monitoring purposes, represent a composite between highdemand and domestic wells and are not easily categorized. To make statistical comparisons easier, commercial, stock, and monitoring wells have been included with the nondomestic wells.

\section{Well Yield}

Reported well-yield data for wells in Adams County are given in table 2 . The rate at which a well can produce water is usually estimated by the driller at the time of drilling. Individual estimates of yield may not be accurate or precise, but the average from a large number of wells is useful for determining if a hydrogeologic unit or geologic formation is able to supply adequate quantities of water for a specified use. Typically, the driller determines the yield after completing a well by measuring or estimating the rate at which water must be either blown or bailed from the well to lower the water level in the borehole or well casing. The accuracy of this estimate is limited because the tests are commonly short in duration (typically 1 hour or less) and the ability of the drill rig commonly is not sufficient to lower the water level significantly in wells with high yields (Taylor and Royer, 1981).

The minimum well yield for a sufficient domestic supply is about 3 to $5 \mathrm{gal} / \mathrm{min}$ (Taylor and Royer, 1981; Waller, 1989). The $3 \mathrm{gal} / \mathrm{min}$ minimum, however, is not met by more than 10 percent of the domestic wells drilled in the Blue Ridge, Piedmont Lowland, and Piedmont Upland (table 2). Greater yields are needed for most other wells classified as nondomestic, but the requirement is variable. In southeastern Pennsylvania, the median well yield for publicsupply wells was reported to be $200 \mathrm{gal} / \mathrm{min}$ in carbonate rocks, $121 \mathrm{gal} / \mathrm{min}$ in sandstone and shale, and $43 \mathrm{gal} / \mathrm{min}$ in crystalline rocks (Risser and Barton, 1995, p. 4). In Adams County, the median yields of domestic and nondomestic wells among the four hydrogeologic units range from 7.0 to 10 and 5.0 to $30 \mathrm{gal} / \mathrm{min}$, respectively (table 2). 
Table 2. Reported well yield by hydrogeologic unit, geologic formation, and water use, Adams County, Pennsylvania [N, number of wells; Min, minimum; 10th, 10th percentile; Med, Median; 90th, 90th percentile; Max, Maximum; --, too few data to compute statistic]

\begin{tabular}{|c|c|c|c|c|c|c|c|c|c|c|c|c|}
\hline \multirow{3}{*}{$\begin{array}{l}\text { Hydrogeologic unit and } \\
\text { geologic formation (with abbreviation }{ }^{1} \text { ) }\end{array}$} & \multicolumn{12}{|c|}{ Well yield, in gallons per minute } \\
\hline & \multicolumn{6}{|c|}{ Domestic wells } & \multicolumn{6}{|c|}{ Nondomestic wells } \\
\hline & $\mathrm{N}$ & Min & 10th & Med & 90th & Max & $\mathrm{N}$ & Min & 10th & Med & 90th & Max \\
\hline Gettysburg Lowland Hydrogeologic Unit & 1,197 & 0.3 & 3.0 & 10 & 30 & 150 & 335 & 0.0 & 1.3 & 17 & 150 & 800 \\
\hline Diabase (Trd) & 215 & .3 & 1.0 & 7.0 & 30 & 100 & 44 & .0 & 1.0 & 7.8 & 25 & 100 \\
\hline Gettysburg Formation (Trg) & 688 & .5 & 4.0 & 12 & 40 & 150 & 238 & .0 & 1.5 & 20 & 180 & 800 \\
\hline New Oxford Formation (Trn) & 292 & .5 & 3.0 & 7.0 & 20 & 100 & 52 & 1.0 & 3.0 & 13 & 90 & 350 \\
\hline Beekmantown Group (Ob) & 2 & 12 & -- & 12 & -- & 12 & 1 & -- & -- & -- & -- & 10 \\
\hline Blue Ridge Hydrogeologic Unit & 306 & .3 & 2.0 & 7.0 & 30 & 100 & 35 & .3 & 1.0 & 18 & 95 & 500 \\
\hline Harpers Formation (Ch) & 13 & .3 & .5 & 7.0 & 60 & 60 & 6 & .3 & -- & 8.5 & -- & 30 \\
\hline Weverton Formation (Cw) & 6 & .5 & -- & 9.0 & -- & 25 & 1 & -- & -- & -- & -- & 10 \\
\hline Metabasalt (mb) & 61 & .3 & 1.0 & 5.0 & 20 & 50 & 1 & -- & -- & -- & -- & 5.0 \\
\hline Metarhyolite (mr) & 203 & .5 & 2.0 & 8.0 & 30 & 100 & 26 & 1.0 & 1.0 & 20 & 150 & 500 \\
\hline Greenstone Schist (vs) & 23 & 1.5 & 2.0 & 6.5 & 20 & 30 & 1 & -- & -- & -- & -- & 8.0 \\
\hline Piedmont Lowland Hydrogeologic Unit & 97 & .5 & 1.5 & 8.0 & 30 & 150 & 35 & 2.0 & 4.3 & 30 & 300 & 400 \\
\hline Conestoga Formation (OCc) & 62 & .5 & 1.5 & 6.0 & 30 & 65 & 24 & 3.0 & 9.0 & 35 & 350 & 400 \\
\hline Ledger Formation $(\mathrm{Cl})$ & 8 & 3.0 & -- & 11 & -- & 30 & 1 & -- & -- & -- & -- & 45 \\
\hline Kinzers Formation (Ck) & 21 & 1.0 & 3.0 & 10 & 50 & 150 & 6 & 3.0 & -- & 25 & -- & 52 \\
\hline Vintage Formation $(\mathrm{Cv})$ & 6 & 2.0 & -- & 16 & -- & 50 & 4 & 2.0 & -- & 10 & -- & 40 \\
\hline Piedmont Upland Hydrogeologic Unit & 90 & .5 & 2.0 & 7.0 & 20 & 35 & 3 & 3.0 & $-\overline{-}$ & 5.0 & -- & 17 \\
\hline Antietam Formation $(\mathrm{Ca})$ & 3 & 4.0 & -- & 5.0 & -- & 10 & 1 & -- & -- & -- & -- & 3.0 \\
\hline Harpers Formation (Ch) & 46 & 1.0 & 2.5 & 8.9 & 20 & 35 & 2 & 5.0 & -- & 11 & -- & 17 \\
\hline Chickies Formation (Cch) & 5 & .5 & -- & 4.0 & -- & 12 & 0 & -- & -- & -- & -- & -- \\
\hline Marburg Schist (Xwm) & 17 & 1.0 & 1.5 & 8.0 & 16 & 20 & 0 & -- & -- & -- & -- & -- \\
\hline Metabasalt (mb) & 19 & 1.0 & 2.0 & 6.0 & 20 & 22 & 0 & -- & -- & -- & -- & -- \\
\hline
\end{tabular}

${ }^{1}$ Abbreviation of geologic formations allows identification on the digital geologic map of Adams County, available through the USGS web site (http://pa.water.usgs.gov). 
A statistical comparison of well yields by water use and geologic formations indicated some variation. The reported yields of nondomestic wells drilled in the Conestoga, Gettysburg, and New Oxford Formations and the metarhyolite are significantly greater than the reported yields of domestic wells in the respective geologic formations. The reported yields of nondomestic wells in the Conestoga Formation are significantly greater than in the diabase. Domestic wells drilled in the Gettysburg Formation have significantly greater reported yields than domestic wells drilled in the diabase, metarhyolite, metabasalt (Blue Ridge), and the New Oxford Formation.

Topographic position affects the reported yields of wells in most bedrock aquifers. In general, wells in valleys have higher yields than wells on slopes or hilltops. This can be explained by the fact that valleys and upland draws form where the rocks are most susceptible to physical or chemical weathering, due largely to the existence of fractures and voids in the rocks. Hilltops are underlain by the more resistant rocks and commonly contain a smaller number of fractures or voids. Wood (1980) found that domestic wells in the Gettysburg Formation and diabase generally have greater yields in valleys than on slopes. Becher and Taylor (1982) found that topography strongly influenced reported yields of carbonate rocks in adjacent Franklin County. A statistical analysis of well yields by topographic setting according to water use for this report also indicated some variation. The statistical analysis, however, indicated topography did not significantly affect the reported yields of domestic wells. Topographic setting was, however, a significant factor for some nondomestic wells drilled in the Gettysburg Formation. Reported yields of nondomestic wells located in valleys were significantly greater (median yield $=54 \mathrm{gal} / \mathrm{min}$ ) than the reported yields from wells drilled on slopes $(15 \mathrm{gal} / \mathrm{min})$ or on broad, flat surface expressions ( $20 \mathrm{gal} / \mathrm{min})$.

The location of a well can significantly affect its ability to yield water. For example, the two most productive nondomestic wells in the Conestoga Formation are located within $100 \mathrm{ft}$ of an abandoned, water-filled quarry near Littlestown, $\mathrm{Pa}$., and within several hundred feet of the New Oxford Formation, Kinzers Formation, and a diabase dike. Both wells are 80 to $85 \mathrm{ft}$ deep with only $15 \mathrm{ft}$ of casing. The shallow well depths, shallow water table, and proximity of several different geologic formations suggest these wells were drilled in an area of structural weakness that favored development of very permeable and transmissive, water-bearing, bedrock fractures. Such a detailed analysis of the 2,098 wells with reported yields, however, was beyond the scope of this investigation. As an aid in the spatial analysis of well yield, the locations of wells with reported yields representing the lower 10 percent and the upper 10 percent by water use and geologic formation are shown in figure 4 . A few selected locations representing wells drilled in the diabase and the Gettysburg and New Oxford Formations were investigated to evaluate possible physical factors affecting the reported yield. Aside from extreme local variability, no definite pattern of high or low reported yield with proximity to streams or other surface water bodies, faults, geologic contacts, geologic formation, or topography was determined.

On the basis of the median domestic well yields (table 2), the Gettysburg Formation, Beekmantown Group, and Vintage Formation are the best yielding geologic formations in Adams County. The least productive geol ogic formations appear to be the Chickies Formation, Antietam Formation, and the metabasalt of the Blue Ridge. With the exception of the Gettysburg Formation, the medians are based on a small sample population. Ther efore, the medians for reported yield may change markedly with the inclusion of additional reported yield data.

In the Piedmont Lowland, the Conestoga Formation appears to be the lowest yielding geologic formation for domestic wells (table 2). The low yields may be due in part to the presence of intervening shale beds that can act as barriers to ground-water flow. Reported yields from domestic wells in the Piedmont Upland are similar to those for the Blue Ridge (table 2). On the basis of the median reported yields of domestic wells, the Marburg Schist appears to be one of the best yielding geologic formations. Recent work in southeastern Pennsylvania (D.J. Low and others, U.S. Geological Survey, written commun., 1998) however, indicates that the Marburg Schist is actually one of the lowest yielding geologic formations in the Piedmont Upland. Work at the Keystone Sanitation Superfund Site also indicates that the Marburg Schist is a very low yielding formation (Kevin Killmartin, Haliburton-NUS, Inc., written commun., 1995). 


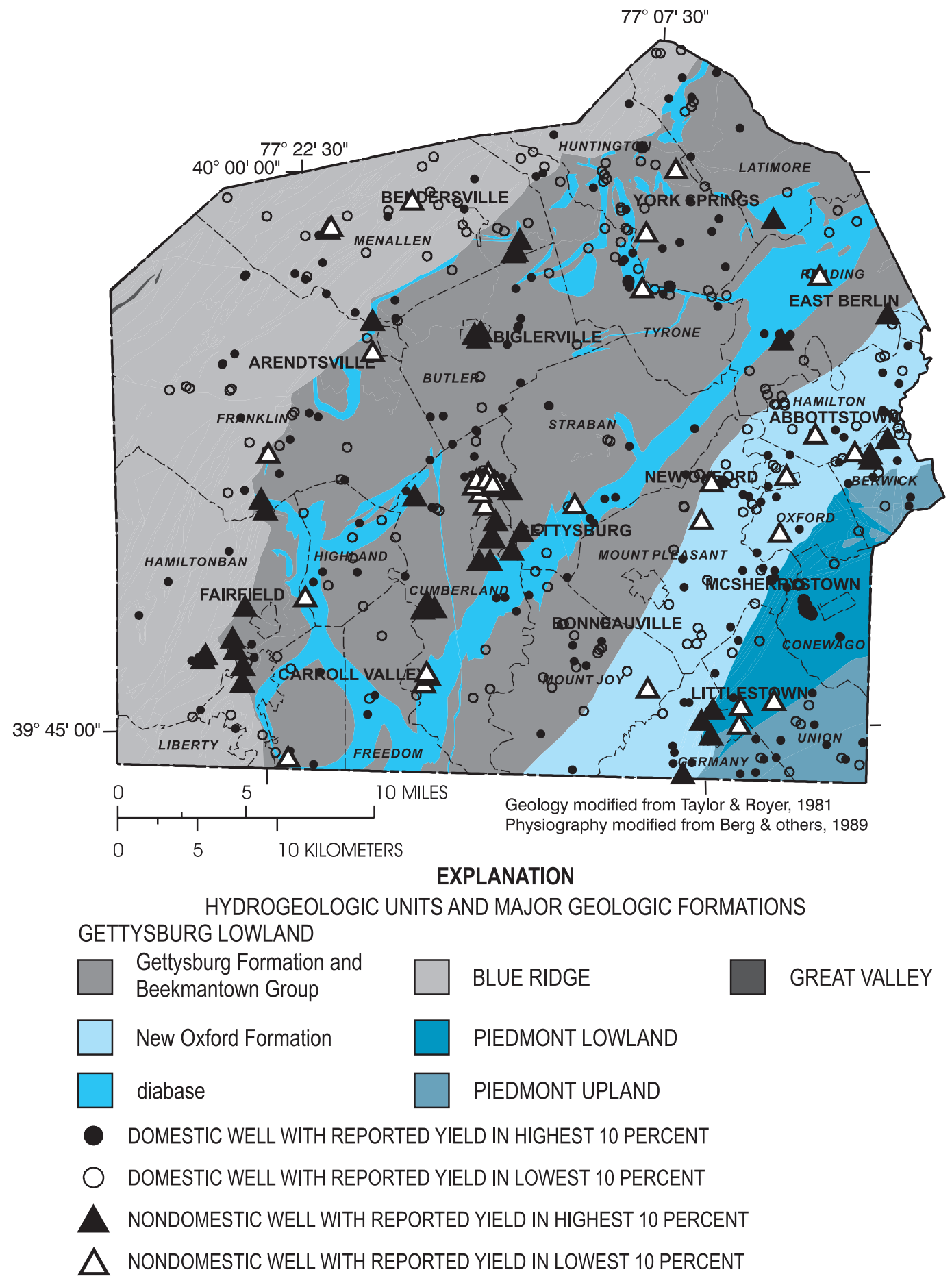

Figure 4. Location of domestic and nondomestic wells that are in the lower and upper 10 percent of reported yields for selected geologic formations. 


\section{Specific Capacity}

Specific capacity, expressed in gallons per minute per foot of drawdown, relates the rate at which water is withdrawn from a well to the amount of drawdown caused by that withdrawal at a given time (table 3). Specific capacity is a more reliable estimate of the water-yielding capability of a geologic formation than reported yield because drawdown and well discharge (pumping rate) are typically measured. The specific capacity of a well decreases for a given pumping rate as drawdown (and usually time) increases. Unfortunately, specific capacity is not reported as frequently as well yield.

Although the total number of wells with specific-capacity data is relatively small, the relations between specific capacity and geologic formation are generally similar to those for well yield. For example, domestic wells drilled in the
Vintage Formation have the highest median reported yield (table 2) and the second highest median specific capacity (table 3 ). For nondomestic wells, the diabase has the lowest median reported yield and the lowest median specific capacity.

A statistical comparison of specific capacity by water use and geologic formations indicated some variation. Nondomestic wells completed in the Gettysburg and Conestoga Formations have significantly greater specific capacities than domestic wells. The specific capacities of nondomestic wells drilled in the Conestoga Formation (table 3 ) are significantly greater than the specific capacities of nondomestic wells drilled in the Gettysburg and New Oxford Formations, diabase, and metarhyolite. For domestic wells, however, there are no significant differences between specific capacities and geologic formations.

Table 3. Specific capacity by hydrogeologic unit, geologic formation, and water use, Adams County, Pennsylvania

[N, number of wells; Min, minimum; 10th, 10th percentile; Med, Median; 90th, 90th percentile; Max, Maximum; --, too few data to compute statistic]

\begin{tabular}{|c|c|c|c|c|c|c|c|c|c|c|c|c|}
\hline \multirow{3}{*}{$\begin{array}{l}\text { Hydrogeologic unit and } \\
\text { geologic formation } \\
\text { (with abbreviation) }\end{array}$} & \multicolumn{12}{|c|}{ Specific capacity, in gallons per minute per foot of drawdown } \\
\hline & \multicolumn{6}{|c|}{ Domestic wells } & \multicolumn{6}{|c|}{ Nondomestic wells } \\
\hline & $\mathrm{N}$ & Min & 10th & Med & 90th & Max & $\mathrm{N}$ & Min & 10th & Med & 90th & Max \\
\hline Gettysburg Lowland & 345 & 0.00 & 0.02 & 0.14 & 0.80 & 40 & 152 & 0.00 & 0.02 & 0.23 & 2.7 & 20 \\
\hline Diabase (Trd) & 63 & .00 & .00 & .07 & 1.2 & 3.0 & 13 & .00 & .01 & .07 & .17 & .39 \\
\hline Gettysburg Formation (Trg)) & 207 & .00 & .03 & .16 & .77 & 40 & 120 & .00 & .03 & .29 & 3.0 & 20 \\
\hline New Oxford Formation (Trn) & 74 & .00 & .02 & .11 & .50 & 1.7 & 19 & .01 & .02 & .11 & 1.5 & 5.0 \\
\hline Beekmantown Group (Ob) & 1 & -- & -- & -- & -- & .08 & 0 & -- & -- & -- & - & - \\
\hline Blue Ridge & 83 & .00 & .01 & .24 & 2.0 & 15 & 14 & .00 & .04 & .26 & 1.3 & 2.8 \\
\hline Harpers Formation (Ch) & 5 & .00 & -- & 1.5 & -- & 4.0 & 2 & .00 & -- & .19 & -- & .38 \\
\hline Weverton Formation $(\mathrm{Cw})$ & 1 & -- & -- & -- & -- & .50 & 0 & -- & -- & -- & -- & -- \\
\hline Metabasalt (mb) & 25 & .00 & .01 & .15 & 6.0 & 15 & 1 & -- & -- & -- & -- & .04 \\
\hline Metarhyolite (mr) & 51 & .00 & .01 & .24 & 1.2 & 7.5 & 10 & .10 & .11 & .45 & 2.0 & 2.8 \\
\hline Greenstone Schist (vs) & 1 & - & - & - & - & 1.5 & 1 & -- & - & - & - & .06 \\
\hline Piedmont Lowland & 23 & .01 & .03 & .11 & .66 & .94 & 14 & .02 & .10 & 2.3 & 35 & 35 \\
\hline Conestoga Formation (OCc) & 9 & .01 & -- & .11 & -- & .94 & 12 & .10 & .22 & 2.8 & 35 & 35 \\
\hline Ledger Formation $(\mathrm{Cl})$ & 6 & .02 & -- & .21 & -- & .79 & 1 & -- & -- & -- & -- & 1.8 \\
\hline Kinzers Formation (Ck) & 5 & .03 & -- & .07 & -- & .17 & 1 & -- & -- & -- & - & .02 \\
\hline Vintage Formation (Cv) & 3 & .04 & - & .31 & - & .66 & 0 & - & - & -- & - & - \\
\hline Piedmont Upland & 31 & .01 & .04 & .15 & .67 & 1.9 & 1 & 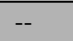 & - & - & - & .08 \\
\hline Antietam Formation (Ca) & 2 & .04 & -- & .07 & -- & .09 & 0 & -- & -- & -- & -- & -- \\
\hline Harpers Formation (Ch) & 20 & .01 & .05 & .16 & .74 & 1.9 & 1 & - & - & -- & - & .08 \\
\hline Chickies Formation (Cc) & 1 & -- & -- & -- & -- & .25 & 0 & -- & -- & -- & - & -- \\
\hline Marburg Schist (Xwm) & 6 & .07 & -- & .26 & -- & .91 & 0 & -- & -- & -- & -- & -- \\
\hline Metabasalt (mb) & 3 & .01 & -- & .03 & -- & .24 & 0 & -- & -- & -- & -- & -- \\
\hline
\end{tabular}


Topographic position does not significantly affect specific capacity. However, Wood (1980, table 6) found that the median specific capacities of domestic and nondomestic wells were greater in valleys of the Gettysburg Formation than on its slopes or hilltops. A similar pattern also was observed for the Gettysburg Formation of Adams County. The median specific capacities of domestic wells drilled in valleys, slopes, and hilltops of the Gettysburg Formation are 0.20, 0.14, and 0.18 (gal/min) $/ \mathrm{ft}$. For nondomestic wells, the median specific capacities in valleys is $0.76(\mathrm{gal} / \mathrm{min}) / \mathrm{ft}$, slopes $0.18(\mathrm{gal} / \mathrm{min}) / \mathrm{ft}$, and hilltops $0.62(\mathrm{gal} / \mathrm{min}) / \mathrm{ft}$. Analysis of specific capacity and topographic setting for the other geologic units in Adams County is not meaningful because of the small sample population.

Well location can significantly affect specific capacity. For example, the specific capacities of four nondomestic wells drilled in the Conestoga Formation and located within $200 \mathrm{ft}$ of a creek or pond are $3.1,29,35$, and $35(\mathrm{gal} / \mathrm{min}) / \mathrm{ft}$. The specific capacities of these four wells are considerably greater than the median specific capacity of 2.1 (gal $/ \mathrm{min}$ ) $/ \mathrm{ft}$ for nondomestic wells in the Conestoga Formation. Another nondomestic well with a specific capacity of $3.1(\mathrm{gal} / \mathrm{min}) / \mathrm{ft}$, however, is not located in proximity to a creek or pond. This suggests that, like well yield, local variability is an important factor in determining the final discharge capacity of a well. The locations of domestic and nondomestic wells with specific capacities represented by the lower 10 percent and the upper 10 percent are shown in figure 5 .

In a more detailed study, Knopman (1990) statistically analyzed a number of factors affecting the specific capacity of wells in the Piedmont and Valley and Ridge Physiographic Provinces of Pennsylvania. She found factors such as lithology, water use, casing diameter, topographic setting, well depth, and casing depth could explain between 40 and about 50 percent of the variation in specific capacity. The two most important factors affecting specific capacity were water use and casing diameter (accounting for 15 and 18 percent of the data variability, respectively). In summary, one must account for differences in factors related to well construction before attempting to assess the yield or discharge potential of geologic formations related to natural factors.

\section{Well Depth}

Estimates of the costs of well construction can be improved if the range of typical drilling depths required to complete a domestic or nondomestic well is known. Wells are generally drilled as deep as necessary to produce adequate supplies of good quality water; thus, domestic wells may not be as deep as nondomestic wells that require greater yields. Well-depth data for Adams County are quite varied, ranging from $20 \mathrm{ft}$ in the diabase to $900 \mathrm{ft}$ in the Gettysburg Formation (table 4).

Well depth is influenced by intended water use (table 4). Nondomestic wells commonly are completed at significantly greater depths than domestic wells in the Gettysburg, New Oxford, Conestoga, and Kinzers Formations and the metarhyolite. Domestic wells drilled in the Harpers Formation of the Blue Ridge are significantly deeper than domestic wells in the Gettysburg, New Oxford, Conestoga, and Harpers Formations, the diabase, and the metarhyolite. Domestic wells drilled in the metabasalt of the Blue Ridge are significantly deeper than domestic wells in the Gettysburg and New Oxford Formations and the Harpers Formation of the Piedmont Upland. The depths of nondomestic wells, however, did not exhibit significant variation by geologic formation.

\section{Water Levels}

Ground-water levels fluctuate in response to recharge from precipitation, discharge from pumping wells, evapotranspiration, inflow from or outflow to streams, and many other factors. Water levels generally rise during the late fall, winter, and early spring when evapotranspiration is at a minimum and recharge is at maximum. Water levels generally decline during the late spring, summer, and early fall when evapotranspiration is at a maximum and recharge is at a minimum. Water levels also are affected by topographic setting and the number of water-bearing zones penetrated. Water levels tend to be shallower (nearer to land surface) in valleys than on slopes or hilltops. Water levels in wells that penetrate more than one water-bearing zone represent a composite of the water levels in each individual zone (Bennett and Patten, 1960). 


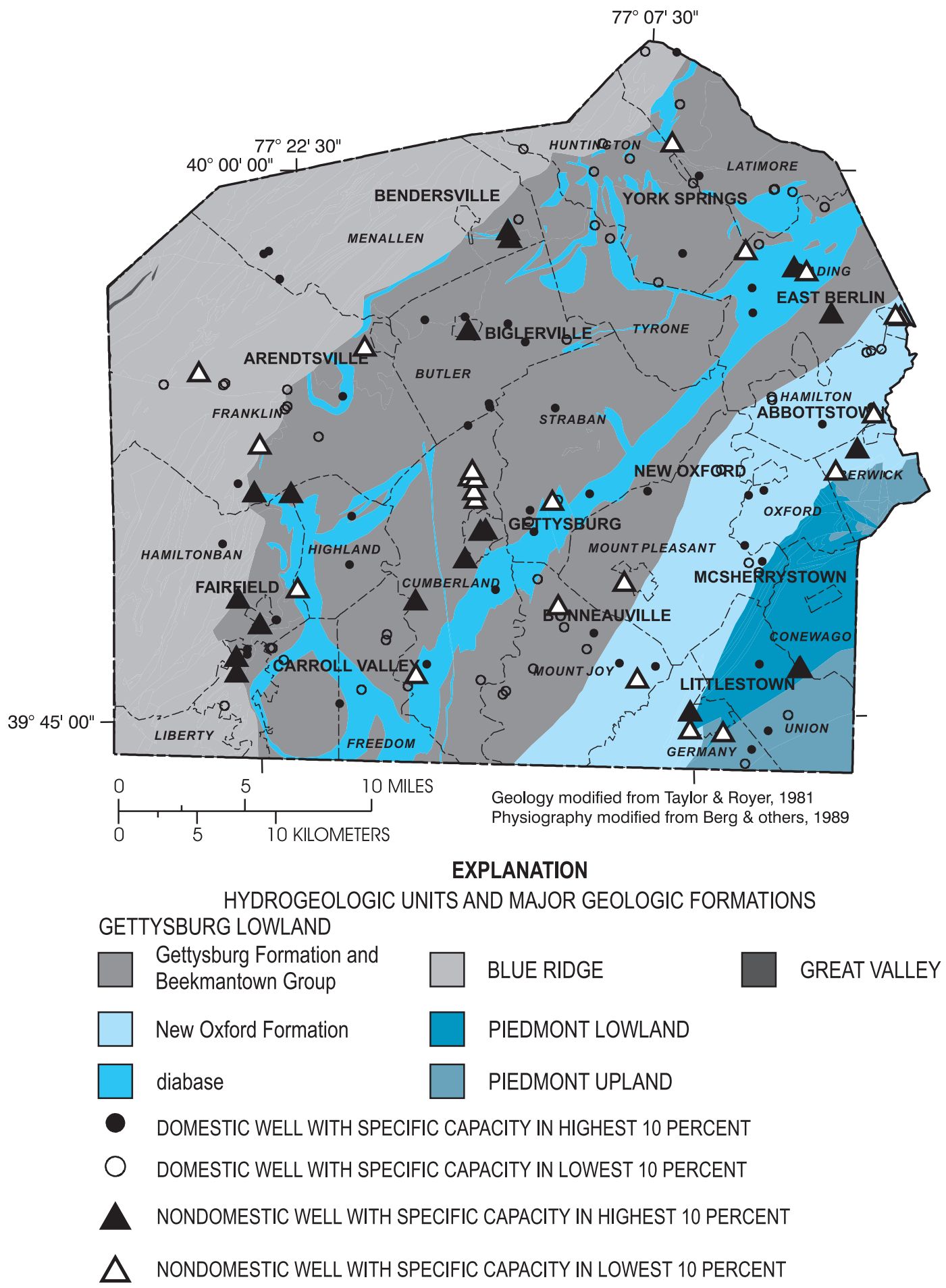

Figure 5. Location of domestic and nondomestic wells that are in the lower and upper 10 percent of reported specific capacities for selected geologic formations. 
Table 4. Well depth by hydrogeologic unit, geologic formation, and water use, Adams County, Pennsylvania

[N, number of wells; Min, minimum; 10th, 10th percentile; Med, Median; 90th, 90th percentile; Max, Maximum; ,-- too few data to compute statistic]

\begin{tabular}{|c|c|c|c|c|c|c|c|c|c|c|c|c|}
\hline \multirow{3}{*}{$\begin{array}{l}\text { Hydrogeologic unit and } \\
\text { geologic formation } \\
\text { (with abbreviation) }\end{array}$} & \multicolumn{12}{|c|}{ Depth of wells, in feet below land surface } \\
\hline & \multicolumn{6}{|c|}{ Domestic wells } & \multicolumn{6}{|c|}{ Nondomestic wells } \\
\hline & $\mathrm{N}$ & Min & 10th & Med & 90th & Max & $\mathrm{N}$ & Min & 10th & Med & 90th & Max \\
\hline Gettysburg Lowland & 1,285 & 20 & 82 & 151 & 300 & 700 & 400 & 11 & 55 & 200 & 500 & 900 \\
\hline Diabase (Trd) & 231 & 20 & 70 & 155 & 350 & 700 & 57 & 12 & 35 & 180 & 460 & 750 \\
\hline Gettysburg Formation (Trg) & 726 & 35 & 85 & 150 & 300 & 600 & 276 & 11 & 54 & 200 & 500 & 900 \\
\hline New Oxford Formation (Trn) & 327 & 40 & 95 & 160 & 300 & 601 & 66 & 20 & 59 & 200 & 550 & 700 \\
\hline Beekmantown Group (Ob) & 1 & -- & -- & -- & -- & 68 & 1 & -- & -- & -- & -- & 247 \\
\hline Blue Ridge & 316 & 47 & 80 & 160 & 369 & 700 & 38 & 30 & 100 & 223 & 430 & 600 \\
\hline Harpers Formation (Ch) & 15 & 50 & 75 & 306 & 500 & 675 & 6 & 212 & -- & 311 & -- & 500 \\
\hline Weverton Formation $(\mathrm{Cw})$ & 6 & 60 & -- & 190 & -- & 425 & 1 & -- & -- & -- & -- & 30 \\
\hline Metabasalt (mb) & 64 & 60 & 90 & 175 & 400 & 700 & 1 & -- & -- & -- & -- & 200 \\
\hline Metarhyolite (mr) & 208 & 47 & 80 & 160 & 310 & 540 & 29 & 77 & 100 & 215 & 430 & 600 \\
\hline Greenstone Schist (vs) & 23 & 55 & 85 & 145 & 369 & 410 & 1 & -- & -- & -- & -- & 180 \\
\hline Piedmont Lowland & 100 & 60 & 95 & 150 & 308 & 575 & 35 & 80 & 135 & 300 & 429 & 675 \\
\hline Conestoga Formation (OCc) & 63 & 60 & 80 & 150 & 300 & 575 & 24 & 80 & 135 & 338 & 429 & 498 \\
\hline Ledger Formation (Cl) & 10 & 60 & 85 & 165 & 400 & 500 & 1 & -- & -- & -- & -- & 150 \\
\hline Kinzers Formation (Ck) & 21 & 100 & 110 & 145 & 261 & 424 & 6 & 150 & -- & 294 & -- & 400 \\
\hline Vintage Formation $(\mathrm{Cv})$ & 6 & 150 & -- & 305 & -- & 375 & 4 & 135 & -- & 188 & -- & 675 \\
\hline Piedmont Upland & 98 & 75 & 100 & 154 & 300 & 550 & 3 & 135 & - & 400 & -- & 510 \\
\hline Antietam Formation (Ca) & 4 & 80 & -- & 128 & -- & 200 & 1 & -- & -- & -- & -- & 400 \\
\hline Harpers Formation (Ch) & 49 & 75 & 90 & 140 & 225 & 300 & 2 & 135 & -- & 323 & -- & 510 \\
\hline Chickies Formation (Cch) & 5 & 80 & -- & 350 & -- & 550 & 0 & -- & -- & -- & -- & -- \\
\hline Marburg Schist (Xwm) & 21 & 100 & 110 & 205 & 300 & 300 & 0 & -- & -- & -- & -- & -- \\
\hline Metabasalt (mb) & 19 & 80 & 100 & 250 & 400 & 500 & 0 & -- & -- & -- & -- & -- \\
\hline
\end{tabular}

Median water levels in the Gettysburg Lowland are shallower than in the Blue Ridge, Piedmont Lowland, and Piedmont Upland (tables 5 and 6). Water levels also show some variation by geologic formation. In wells drilled in the highly resistant diabase, which typically forms topographic highs, water levels are generally much shallower than in wells completed in the less resistant, slope or valley forming sandstone and shale of the Gettysburg Formation or the New Oxford Formation. The shallow water levels in the diabase may be in part the result of its generally low permeability or that a large number of waterbearing zones are penetrated at shallow depths. Twenty-seven of 48 (56 percent) water-bearing zones identified in 38 wells drilled in the diabase were penetrated by a depth of $100 \mathrm{ft}$. For the Gettysburg Formation, 81 of 213 (38 percent) water-bearing zones identified in 133 wells were penetrated by a depth of $100 \mathrm{ft}$. In the New Oxford Formation, 7 of 13 (54 percent) water-bearing zones identified in 10 wells were penetrated by a depth of $100 \mathrm{ft}$.

\section{Overburden Thickness}

The overburden (or regolith) consists of weathered rock, soil, alluvium, and colluvium of varying thicknesses that overlie competent bedrock. Overburden thickness was estimated from driller's records of reported depth-tobedrock. Because the overburden contact between weathered and solid competent bedrock is usually gradational in Adams County, these estimates should be considered approximate. The zone of unconsolidated material and weathered bedrock has a higher porosity than the competent bedrock and also may be more permeable, depending on its composition. The overburden serves as a storage reservoir to the underlying bedrock because its percentage of void space is many times greater than in the bedrock. It receives recharge, generally through precipitation, and stores this water in the interstices between individual mineral grains. As water from the bedrock aquifers is depleted, water from the overburden flows slowly downward into bedrock fractures, joints, or bedding planes. Because water must pass through this zone to 
Table 5. Water levels by hydrogeologic unit, geologic formation, and water use, Adams County, Pennsylvania [N, number of wells; Min, minimum; 10th, 10th percentile; Med, Median; 90th, 90th percentile; Max, Maximum; ,-- too few data to compute statistic; negative water levels indicate flowing wells]

\begin{tabular}{|c|c|c|c|c|c|c|c|c|c|c|c|c|}
\hline \multirow{3}{*}{$\begin{array}{l}\text { Hydrogeologic unit and } \\
\text { geologic formation } \\
\text { (with abbreviation) }\end{array}$} & \multicolumn{12}{|c|}{ Water levels, in feet below land surface } \\
\hline & \multicolumn{6}{|c|}{ Domestic wells } & \multicolumn{6}{|c|}{ Nondomestic wells } \\
\hline & $\mathrm{N}$ & Min & 10th & Med & 90th & $\operatorname{Max}$ & $\mathrm{N}$ & Min & 10th & Med & 90th & Max \\
\hline Gettysburg Lowland & 927 & 1.0 & 6.0 & 22 & 50 & 270 & 340 & -1.2 & 4.6 & 16 & 56 & 368 \\
\hline Diabase (Trd) & 174 & 1.6 & 4.6 & 17 & 50 & 240 & 45 & 0.0 & 3.3 & 11 & 50 & 368 \\
\hline Gettysburg Formation (Trg) & 527 & 1.0 & 8.0 & 25 & 52 & 270 & 222 & -1.2 & 5.0 & 18 & 57 & 160 \\
\hline New Oxford Formation (Trn) & 224 & 2.0 & 7.4 & 22 & 50 & 138 & 73 & 1.8 & 3.7 & 15 & 56 & 143 \\
\hline Beekmantown Group (Ob) & 2 & 27 & -- & 46 & -- & 65 & 0 & -- & -- & -- & -- & -- \\
\hline Blue Ridge & 256 & 1.0 & 6.1 & 30 & 60 & 300 & 20 & 4.0 & 8.3 & 25 & 75 & 100 \\
\hline Harpers Formation (Ch) & 11 & 7.6 & 10 & 33 & 295 & 300 & 5 & 16 & -- & 30 & -- & 34 \\
\hline Weverton Formation $(\mathrm{Cw})$ & 3 & 8.0 & -- & 15 & -- & 26 & 0 & -- & -- & -- & -- & -- \\
\hline Metabasalt (mb) & 61 & 3.0 & 10 & 30 & 60 & 100 & 1 & -- & -- & -- & -- & 44 \\
\hline Metarhyolite (mr) & 164 & 1.0 & 6.0 & 28 & 60 & 130 & 13 & 4.0 & 5.5 & 19 & 80 & 100 \\
\hline Greenstone Schist (vs) & 17 & 7.0 & 14 & 36 & 56 & 90 & 1 & -- & -- & -- & -- & 28 \\
\hline Piedmont Lowland & 77 & 3.0 & 10 & 27 & 54 & 105 & 25 & -.9 & 3.3 & 14 & 60 & 114 \\
\hline Conestoga Formation (OCc) & 51 & 6.0 & 9.9 & 29 & 50 & 100 & 18 & -.9 & 0.0 & 6.5 & 79 & 114 \\
\hline Ledger Formation $(\mathrm{Cl})$ & 8 & 22 & -- & 28 & -- & 105 & 1 & -- & -- & -- & -- & 14.3 \\
\hline Kinzers Formation (Ck) & 12 & 10 & 13 & 25 & 42 & 54 & 6 & 12 & -- & 20 & -- & 60 \\
\hline Vintage Formation $(\mathrm{Cv})$ & 6 & 3.0 & -- & 38 & -- & 89 & 0 & -- & -- & -- & -- & -- \\
\hline Piedmont Upland & 71 & 7.0 & 15 & 33 & 50 & 125 & 2 & 24.5 & - & 27 & -- & 30 \\
\hline Antietam Formation (Ca) & 3 & 19 & -- & 28 & -- & 32 & 1 & -- & -- & -- & -- & 30 \\
\hline Harpers Formation (Ch) & 36 & 7.0 & 14 & 28 & 45 & 60 & 1 & -- & -- & -- & -- & 25 \\
\hline Chickies Formation (Cch) & 4 & 20 & -- & 45 & -- & 125 & 0 & -- & -- & -- & -- & -- \\
\hline Marburg Schist (Xwm) & 15 & 16 & 20 & 38 & 52 & 60 & 0 & -- & -- & -- & -- & -- \\
\hline Metabasalt (mb) & 13 & 7.0 & 25 & 35 & 50 & 64 & 0 & -- & -- & -- & -- & -- \\
\hline
\end{tabular}

Table 6. Summary statistics for water level by hydrogeologic unit and topographic setting, Adams County, Pennsylvania

[N, number of wells; Min, minimum; 10th, 10th percentile; Med, median; 90th, 90th percentile; Max, maximum; depth in feet below land surface; --, too few data to compute statistic; negative water levels indicate flowing wells]

\begin{tabular}{|c|c|c|c|c|c|c|c|c|c|c|c|c|}
\hline \multirow{3}{*}{ Hydrogeologic unit } & \multicolumn{12}{|c|}{ Water levels, in feet below land surface } \\
\hline & \multicolumn{6}{|c|}{ Flat surface } & \multicolumn{6}{|c|}{ Hilltop } \\
\hline & $\mathrm{N}$ & Min & 10th & Med & 90th & Max & $\mathrm{N}$ & Min & 10th & Med & 90th & Max \\
\hline Gettysburg Lowland & 326 & 2.0 & 7.0 & 22 & 46 & 107 & 77 & 1.0 & 6.0 & 20 & 53 & 100 \\
\hline Blue Ridge & 8 & 7.0 & -- & 33 & -- & 60 & 7 & 11 & -- & 35 & -- & 84 \\
\hline Piedmont Lowland & 46 & -.9 & 16 & 30 & 60 & 105 & 7 & 13 & -- & 25 & -- & 42 \\
\hline \multirow[t]{3}{*}{ Piedmont Upland } & 5 & 10 & -- & 35 & -- & 60 & 10 & 20 & 20 & 33 & 83 & 125 \\
\hline & \multicolumn{6}{|c|}{ Slope } & \multicolumn{6}{|c|}{ Valley } \\
\hline & $\mathrm{N}$ & Min & 10th & Med & 90th & Max & $\mathrm{N}$ & Min & 10th & Med & 90th & Max \\
\hline Gettysburg Lowland & 684 & -1.2 & 6.0 & 22 & 60 & 368 & 146 & 1.0 & 4.0 & 14 & 36 & 68 \\
\hline Blue Ridge & 194 & 1.0 & 6.1 & 30 & 63 & 300 & 23 & 1.0 & 3.0 & 10 & 41 & 64 \\
\hline Piedmont Lowland & 30 & 3.0 & 6.0 & 23 & 78 & 114 & 7 & 3.3 & -- & 5.0 & -- & 21 \\
\hline Piedmont Upland & 43 & 7.0 & 15 & 30 & 50 & 64 & 1 & -- & -- & -- & -- & 7.0 \\
\hline
\end{tabular}


recharge the underlying bedrock, the thickness and permeability of this zone is one factor used to determine the aquifer's susceptibility to contamination from surface-water sources. The thickness of overburden, or depth-to-bedrock, near a well is related mostly to rock type and to the topographic position of the well.

The reported thickness of overburden varies significantly by water use and geologic formation (table 7). For unknown reasons, drillers' reports from wells drilled for nondomestic purposes in the Gettysburg Formation indicate the wells penetrate significantly less overburden than their domestic counterparts. None of the other geologic formations exhibit significant differences in overburden thickness when analyzing for water use. Differences in overburden thickness among geologic formations for nondomestic wells are not significant. Drillers' reports for domestic wells, however, indicate considerable differences in overburden thickness between geologic formations. Domestic wells drilled in the Harpers Formation of the Blue Ridge penetrate significantly more overburden than domestic wells drilled in the diabase, Gettysburg, New Oxford, Conestoga, and Harpers Formations, metabasalt of the Blue Ridge, metarhyolite, greenstone schist, Marburg Schist, and metabasalt of the Piedmont Upland. Overburden thickness in the metarhyolite is significantly greater than in the diabase and the Gettysburg, New Oxford, and Conestoga Formations. The New Oxford Formation also has an overburden significantly thinner than the Gettysburg Formation, greenstone schist, and metabasalt of the Piedmont Upland. Overburden thickness varies also by topographic setting (table 8 ) but not significantly.

Table 7. Overburden thickness (depth to bedrock) by hydrogeologic unit, geologic formation, and water use, Adams County, Pennsylvania

[N, number of wells; Min, minimum; 10th, 10th percentile; Med, Median; 90th, 90th percentile; Max, Maximum; --, too few data to compute statistic]

\begin{tabular}{|c|c|c|c|c|c|c|c|c|c|c|c|c|}
\hline \multirow{3}{*}{$\begin{array}{l}\text { Hydrogeologic unit and } \\
\text { geologic formation } \\
\text { (with abbreviation) }\end{array}$} & \multicolumn{12}{|c|}{ Overburden thickness, in feet } \\
\hline & \multicolumn{6}{|c|}{ Domestic wells } & \multicolumn{6}{|c|}{ Nondomestic wells } \\
\hline & $\mathrm{N}$ & Min & 10th & Med & 90th & $\operatorname{Max}$ & $\mathrm{N}$ & Min & 10th & Med & 90th & Max \\
\hline Gettysburg Lowland & 923 & 0 & 8 & 24 & 50 & 200 & 216 & 0 & 4 & 14 & 48 & 177 \\
\hline Diabase (Trd) & 149 & 3 & 9 & 23 & 45 & 85 & 25 & 5 & 7 & 15 & 40 & 50 \\
\hline Gettysburg Formation (Trg) & 578 & 1 & 10 & 29 & 51 & 200 & 172 & 1 & 4 & 13 & 49 & 177 \\
\hline New Oxford Formation (Trn) & 194 & 0 & 6 & 16 & 50 & 138 & 19 & 0 & 3 & 21 & 45 & 48 \\
\hline Beekmantown Group (Ob) & 2 & 27 & -- & 46 & -- & 65 & 0 & -- & -- & -- & -- & -- \\
\hline Blue Ridge & 232 & 3 & 14 & 35 & 70 & 256 & 24 & 7 & 9 & 28 & 48 & 55 \\
\hline Harpers Formation (Ch) & 12 & 12 & 31 & 60 & 221 & 256 & 5 & 9 & -- & 18 & -- & 25 \\
\hline Weverton Formation (Cw) & 6 & 20 & -- & 42 & -- & 60 & 1 & -- & -- & -- & -- & 25 \\
\hline Metabasalt (mb) & 52 & 4 & 7 & 30 & 75 & 174 & 1 & -- & -- & -- & -- & 38 \\
\hline Metarhyolite (mr) & 143 & 3 & 18 & 35 & 65 & 180 & 16 & 7 & 7 & 35 & 54 & 55 \\
\hline Greenstone Schist (vs) & 19 & 12 & 22 & 36 & 63 & 97 & 1 & -- & -- & -- & -- & 35 \\
\hline Piedmont Lowland & 57 & 4 & 8 & 18 & 51 & 182 & 12 & 6 & 8 & 22 & 60 & 70 \\
\hline Conestoga Formation (OCc) & 39 & 4 & 12 & 18 & 36 & 53 & 7 & 6 & -- & 8 & -- & 60 \\
\hline Ledger Formation (Cl) & 7 & 6 & -- & 18 & -- & 182 & 1 & -- & -- & -- & -- & 22 \\
\hline Kinzers Formation (Ck) & 8 & 5 & -- & 17 & -- & 75 & 2 & 18 & -- & 20 & -- & 22 \\
\hline Vintage Formation $(\mathrm{Cv})$ & 3 & 6 & -- & 17 & -- & 98 & 2 & 56 & -- & 63 & -- & 70 \\
\hline Piedmont Upland & 63 & 4 & 10 & 24 & 74 & 120 & 0 & -- & -- & -- & -- & $\overline{--}$ \\
\hline Antietam Formation (Ca) & 1 & -- & -- & -- & -- & 54 & 0 & -- & -- & -- & -- & -- \\
\hline Harpers Formation (Ch) & 30 & 4 & 9 & 24 & 75 & 105 & 0 & -- & -- & -- & -- & -- \\
\hline Chickies Formation (Cch) & 3 & 14 & -- & 35 & -- & 46 & 0 & -- & -- & -- & -- & -- \\
\hline Marburg Schist (Xwm) & 16 & 8 & 12 & 21 & 50 & 58 & 0 & -- & -- & -- & -- & -- \\
\hline Metabasalt (mb) & 13 & 8 & 10 & 36 & 92 & 120 & 0 & -- & -- & -- & -- & -- \\
\hline
\end{tabular}


Table 8. Summary statistics for overburden thickness (depth to bedrock) by hydrogeologic unit and topographic setting, Adams County, Pennsylvania

[N, number of wells; Min, minimum; 10th, 10th percentile; Med, median; 90th, 90th percentile; Max, maximum; --, too few data to compute statistic]

\begin{tabular}{|c|c|c|c|c|c|c|c|c|c|c|c|c|}
\hline \multirow{3}{*}{ Hydrogeologic unit } & \multicolumn{12}{|c|}{ Overburden thickness, in feet } \\
\hline & \multicolumn{6}{|c|}{ Flat surface } & \multicolumn{6}{|c|}{ Hilltop } \\
\hline & $\mathrm{N}$ & Min & 10th & Med & 90th & $\operatorname{Max}$ & $\mathrm{N}$ & Min & 10th & Med & 90th & $\operatorname{Max}$ \\
\hline Gettysburg Lowland & 332 & 0 & 8 & 21 & 45 & 151 & 50 & 2 & 5 & 20 & 41 & 85 \\
\hline Blue Ridge & 8 & 31 & -- & 46 & -- & 86 & 8 & 30 & -- & 42 & -- & 58 \\
\hline Piedmont Lowland & 46 & 6 & 8 & 18 & 53 & 75 & 0 & -- & -- & -- & -- & -- \\
\hline \multirow[t]{3}{*}{ Piedmont Upland } & 5 & 5 & -- & 15 & -- & 22 & 3 & 10 & -- & 14 & -- & 36 \\
\hline & \multicolumn{6}{|c|}{ Slope } & \multicolumn{6}{|c|}{ Valley } \\
\hline & $\mathrm{N}$ & Min & 10th & Med & 90th & Max & $\mathrm{N}$ & Min & 10th & Med & 90th & Max \\
\hline Gettysburg Lowland & 626 & 0 & 6 & 24 & 54 & 200 & 92 & 1 & 9 & 21 & 49 & 177 \\
\hline Blue Ridge & 178 & 3 & 16 & 35 & 75 & 256 & 21 & 7 & 17 & 35 & 50 & 75 \\
\hline Piedmont Lowland & 10 & 6 & 7 & 25 & 148 & 182 & 1 & -- & -- & -- & -- & 5 \\
\hline Piedmont Upland & 36 & 4 & 8 & 32 & 75 & 120 & 2 & 77 & -- & 91 & -- & 105 \\
\hline
\end{tabular}

\section{Ground-Water-Quality Data}

Laboratory and field analyses of water samples collected from 352 wells and a tile drain in Adams County from 1950 through 1996 from the WATSTORE, STORET, and GWSI databases are summarized in the following sections. The 10th and 90th percentiles are given rather than the range to exclude extremes caused by anthropogenic effects and measurement errors. Except where adversely affected by human activities, ground water in Adams County is of good quality and suitable for most purposes.

Although the presence of bacteria in water from domestic household-supply wells is widespread in southcentral Pennsylvania (Bickford and others, 1996), only one bacterial analysis was recorded in the WATSTORE and STORET databases for ground water in Adams County. Therefore, bacterial levels in ground water could not be evaluated from these databases.

\section{Field Measurements}

Measurements of selected constituents in the field can provide a rough approximation of the quality of water being collected. Field measurements most frequently made include $\mathrm{pH}$, specific conductance, and temperature. Alkalinity, hardness, and dissolved oxygen also are best measured in the field. These six water-quality characteristics are unstable and can be affected by storage of the sample prior to analysis (Hem, 1985).

The $\mathrm{pH}$ is a measurement of the activity of hydrogen ions in water and is expressed in logarithmic units; a $\mathrm{pH}$ of 7 is considered neutral. Water with a $\mathrm{pH}$ less than 7 is acidic; water with a $\mathrm{pH}$ greater than 7 is basic. Corrosiveness of water generally increases with decreasing $\mathrm{pH}$. 
Lithology strongly affects $\mathrm{pH}$. Water from wells in the Gettysburg Conglomerate, volcanics (metarhyolite and metabasalt), schist, and quartzite (Harpers Formation) is generally acidic; the median $\mathrm{pH}$ of water from the diabase is neutral (table 9). The carbonate rocks and the remaining Triassic age rocks of the Gettysburg Lowland have water that is generally alkaline or basic. Two wells in the Conestoga Formation, however, contain water with a $\mathrm{pH}$ below 7.2. These two wells (AD-744 and AD-745) are located just east of Littlestown, Pa., and within 0.5-0.75 mi of a formational contact with the Antietam Formation. Several possible reasons for the relatively low $\mathrm{pH}$ of water in the two wells include (1) the abundance of shale, which tends to produce slightly acidic water, in the Conestoga Formation or (2) some mixing from more acidic water that originated in the Antietam Formation and migrated to the two wells.

The $\mathrm{pH}$ of water from 16 of the 207 wells sampled for this constituent was lower than the USEPA secondary maximum contaminant level (SMCL) minimum threshold of 6.5. The $\mathrm{pH}$ in water from 4 of the 7 wells sampled in the Piedmont Upland and 6 of the 15 wells sampled in the diabase was less than 6.5. The $\mathrm{pH}$ of water from wells in the Gettysburg Formation ( 3 wells) and the New Oxford Formation ( 3 wells) also was less than 6.5. Another well in the Gettysburg Formation had a $\mathrm{pH}$ of 9.5. The water from this well was apparently contaminated by cement grout that seeped under the well casing.

Specific conductance is a measure of the ability of water to conduct an electric current and is expressed in units of microsiemens per centimeter at 25 degrees Celsius. It varies with concentration and degree of ionization of the constituents. Specific conductance may be used to obtain a rapid estimate of the total dissolved-solids content of water by multiplying the specific conductance by a factor of 0.55 to 0.75 .

The specific conductance of ground water typically has a wide range. In some areas of Adams County, specific conductance has been measured as $50 \mu \mathrm{S} / \mathrm{cm}$ or lower (Harpers Formation, Gettysburg Conglomerate, and metarhyolite). Ground water with such low specific conductance is typically low in solutes (such as dissolved solids), which are common in geologic formations resistant to chemical attack (quartz rich).

Table 9. Field measurements of $\mathrm{pH}$ in ground water from Adams County, Pennsylvania, by hydrogeologic unit and geologic formation

[--, insufficient data available]

\begin{tabular}{lrrrr}
\hline \multirow{2}{*}{$\begin{array}{c}\text { Hydrogeologic unit and } \\
\text { geologic formation } \\
\text { (with abbreviation) }\end{array}$} & $\begin{array}{c}\text { Number } \\
\text { of wells }\end{array}$ & $\begin{array}{c}\text { 10th } \\
\text { percentile }\end{array}$ & Median & $\begin{array}{c}\text { 90th } \\
\text { percentile }\end{array}$ \\
\hline Gettysburg Lowland & 175 & 6.6 & 7.3 & 7.8 \\
Diabase (Trd) & 15 & 6.4 & 7.0 & 7.6 \\
Gettysburg Formation (Trg) & 121 & 6.8 & 7.3 & 7.7 \\
Gettysburg Conglomerate (Trgc) & 9 & 6.5 & 6.9 & 7.9 \\
New Oxford Formation (Trn) & 30 & 6.5 & 7.4 & 7.8 \\
\hline Blue Ridge & 3 & 6.8 & 6.8 & 7.2 \\
Metarhyolite (mr) & 3 & 6.8 & 6.8 & 7.2 \\
\hline Piedmont Lowland & 22 & 7.0 & 7.6 & 7.9 \\
Conestoga Formation (OCc) & 14 & 6.7 & 7.6 & 7.9 \\
Ledger Formation (Cl) & 2 & 7.4 & 7.5 & 7.6 \\
Kinzers Formation (Ck) & 4 & 7.2 & 7.6 & 8.3 \\
Vintage Formation (Cv) & 2 & 7.4 & 7.6 & 7.8 \\
\hline Piedmont Upland & 7 & 5.6 & 6.5 & 7.1 \\
Harpers Formation (Ch) & 3 & 6.3 & 6.8 & 7.1 \\
Marburg Schist (Xwm) & 3 & 5.6 & 5.7 & 6.6 \\
Metabasalt (mb) & 1 & -- & 6.5 & -- \\
\hline
\end{tabular}


As with $\mathrm{pH}$, lithology strongly affects specific conductance. Water from wells in rocks dominated by limestone, dolomite, shale, or siltstone have the highest median specific conductances, ranging from 380 to $795 \mu \mathrm{S} / \mathrm{cm}$ (table 10). Water from wells completed in geologic formations more physically and chemically resistant to weathering have lower median specific conductances. Such formations are more common in the Blue Ridge and the Piedmont Upland.

Wells that contain water with relatively elevated specific conductance $(1,000 \mu \mathrm{S} / \mathrm{cm}$ or greater) are those completed in the Marburg Schist ( 2 wells), metarhyolite (1 well), Kinzers Formation (3 wells), New Oxford Formation (4 wells), diabase ( 1 well), and Gettysburg Formation (4 wells). The reasons for such high specific conductances are not known but may be the result of poor well construction (influence from contaminated surface water) or the presence of ground water enriched in such items as nutrients, deicing compounds, or other types of dissolved solids.

Dissolved oxygen is introduced into ground water through recharge (infiltrating water) and by movement of air through unsaturated material above the water table. Dissolved oxygen may travel considerable distances in ground water if little reactive material (organic compounds or reduced inorganic minerals such as pyrite and siderite) is available (Hem, 1985, p. 155-156). Dissolved oxygen is not an indicator of organic pollution nor does it by itself generally affect usability of the water. However, low dissolved oxygen is usually associated with elevated concentrations of iron, manganese, and hydrogen sulfide. The high concentrations of dissolved

Table 10. Field measurements of specific conductance in ground water from Adams County, Pennsylvania, by hydrogeologic unit and geologic formation

[--, insufficient data available]

\begin{tabular}{|c|c|c|c|c|}
\hline \multirow{2}{*}{$\begin{array}{l}\text { Hydrogeologic unit } \\
\text { and geologic formation } \\
\text { (with abbreviation) }\end{array}$} & \multirow{2}{*}{$\begin{array}{l}\text { Number } \\
\text { of wells }\end{array}$} & \multicolumn{3}{|c|}{$\begin{array}{c}\text { Specific conductance, } \\
\text { in microsiemens per centimeter } \\
\text { at } 25 \text { degrees Celsius }\end{array}$} \\
\hline & & $\begin{array}{c}\text { 10th } \\
\text { percentile }\end{array}$ & Median & $\begin{array}{c}\text { 90th } \\
\text { percentile }\end{array}$ \\
\hline Gettysburg Lowland & 303 & 223 & 435 & 775 \\
\hline Diabase (Trd) & 44 & 220 & 340 & 510 \\
\hline Gettysburg Formation (Trg) & 168 & 321 & 500 & 812 \\
\hline Gettysburg Conglomerate $(\operatorname{Trgc})$ & 24 & 90 & 225 & 350 \\
\hline New Oxford Formation (Trn) & 67 & 190 & 380 & 904 \\
\hline Blue Ridge & 39 & 80 & 169 & 376 \\
\hline Metabasalt (mb) & 6 & 80 & 197 & 312 \\
\hline Metarhyolite (mr) & 27 & 78 & 147 & 376 \\
\hline Greenstone Schist (vs) & 6 & 109 & 260 & 425 \\
\hline Piedmont Lowland & 30 & 332 & 476 & 895 \\
\hline Conestoga Formation (OCc) & 20 & 332 & 403 & 713 \\
\hline Ledger Formation $(\mathrm{Cl})$ & 2 & 439 & 570 & 700 \\
\hline Kinzers Formation (Ck) & 6 & 504 & 795 & 1,150 \\
\hline Vintage Formation $(\mathrm{Cv})$ & 2 & 211 & 385 & 560 \\
\hline Piedmont Upland & 23 & 60 & 211 & 573 \\
\hline Antietam Formation (Ca) & 3 & 170 & 211 & 573 \\
\hline Harpers Formation (Ch) & 10 & 103 & 298 & 586 \\
\hline Marburg Schist (Xwm) & 9 & 60 & 115 & 2,500 \\
\hline Metabasalt (mb) & 1 & -- & 164 & -- \\
\hline
\end{tabular}


oxygen for the diabase and Ledger Formation (table 11) may indicate rapid ground-water flow or recharge and perhaps good hydraulic connection with the land surface. Low concentrations of dissolved oxygen $(0.5 \mathrm{mg} / \mathrm{L}$ or less) are probably the result of oxidation of iron-sulfide minerals.

The alkalinity of water is the capacity for solutes it contains to react with and neutralize acid (Hem, 1985, p. 106). In most cases, alkalinity is produced by dissolved carbon dioxide, bicarbonate, and carbonate. Alkalinity is commonly expressed in terms of an equivalent amount of calcium carbonate. Most carbon dioxide in ground water is produced from the atmosphere, atmospheric gases in the soil, or in the unsaturated zone. Air in the soil and the unsaturated zone can be substantially enriched in carbon dioxide by respiration from plants or the oxidation of organic matter.

Lithology can strongly affect alkalinity (table 12). Alkalinity is considerably lower in the volcanic rocks, schists, and quartzites than in rocks dominated by limestone or dolomite. The relatively high median alkalinities in the Gettysburg and New Oxford Formations may be related to the abundance of calcite in fractures, joints, bedding planes, and other secondary openings. Scattered limestone beds also are present in the Gettysburg Formation.

In most waters, nearly all the hardness is from calcium and magnesium. Carbonate hardness (also called temporary hardness) results from cations in association with carbonate and bicarbonate; it is called temporary because it may be removed by boiling the water. Hard water consumes soap before a lather will form and deposits soap curds on bathtubs. Carbonate hardness is the cause of scale formation in boilers, water heaters, radiators, and pipes, which results in a decrease in heat transfer and restricted flow of water. Hardness usually is expressed in equivalent concentrations of calcium carbonate. Waters of hardness up to $60 \mathrm{mg} / \mathrm{L}$ are considered soft; $61-120 \mathrm{mg} / \mathrm{L}$ are moderately hard; $121-180 \mathrm{mg} / \mathrm{L}$ are hard; and more than $180 \mathrm{mg} / \mathrm{L}$ are very hard (Durfor and Becker, 1964, p. 27). The number of milligrams per liter divided by 17.1 yields the concentration in grains per gallon. Hardness in water used for ordinary domestic purposes does not become particularly objectionable until it reaches a level of about $100 \mathrm{mg} / \mathrm{L}$.

Lithology strongly affects hardness. Water from wells completed in the Conestoga, Ledger, Kinzers, and Vintage Formations, which are dominated by limestone and dolomite, is typically hard to very hard and has the greatest median hardness, ranging from 220 to $270 \mathrm{mg} / \mathrm{L}$ (table 13). The very hard water from the Gettysburg Formation is, in a large part, a consequence of the presence of scattered limestone beds. Water produced from wells completed in the Gettysburg Conglomerate, metarhyolite, metabasalt, Marburg Schist, and Harpers and Antietam Formations is generally soft to moderately hard; the median hardness ranges from 43 to $120 \mathrm{mg} / \mathrm{L}$.

\section{Major lons}

The chemical composition of ground water is derived from many different sources including the atmosphere, soil, bedrock, and human activities. Most dissolved solutes in ground water, in order of decreasing concentration, are bicarbonate, sulfate,

Table 11. Field measurements of dissolved oxygen in ground water from Adams County, Pennsylvania, by hydrogeologic unit and geologic formation

[--, insufficient data available]

\begin{tabular}{|c|c|c|c|c|}
\hline \multirow{2}{*}{$\begin{array}{l}\text { Hydrogeologic unit } \\
\text { and geologic formation } \\
\text { (with abbreviation) }\end{array}$} & \multirow{2}{*}{$\begin{array}{l}\text { Number } \\
\text { of wells }\end{array}$} & \multicolumn{3}{|c|}{$\begin{array}{l}\text { Dissolved oxygen, } \\
\text { in milligrams per liter }\end{array}$} \\
\hline & & $\begin{array}{c}\text { 10th } \\
\text { percentile }\end{array}$ & Median & $\begin{array}{c}\text { 90th } \\
\text { percentile }\end{array}$ \\
\hline Gettysburg Lowland & 56 & 0.10 & 2.50 & 6.40 \\
\hline Diabase (Trd) & 1 & -- & 8.70 & -- \\
\hline Gettysburg Formation (Trg) & 50 & .40 & 2.50 & 6.25 \\
\hline Gettysburg Conglomerate (Trgc) & 5 & .00 & 1.35 & 5.80 \\
\hline Piedmont Lowland & 1 & -- & 6.65 & -- \\
\hline Ledger Formation $(\mathrm{Cl})$ & 1 & -- & 6.65 & -- \\
\hline
\end{tabular}


Table 12. Field measurements of alkalinity in ground water from Adams County, Pennsylvania, by hydrogeologic unit and geologic formation

[--, insufficient data available]

\begin{tabular}{|c|c|c|c|c|}
\hline \multirow{2}{*}{$\begin{array}{l}\text { Hydrogeologic unit } \\
\text { and geologic formation } \\
\text { (with abbreviation) }\end{array}$} & \multirow{2}{*}{$\begin{array}{l}\text { Number } \\
\text { of wells }\end{array}$} & \multicolumn{3}{|c|}{$\begin{array}{l}\text { Alkalinity, in milligrams per liter } \\
\text { as calcium carbonate }\end{array}$} \\
\hline & & $\begin{array}{c}\text { 10th } \\
\text { percentile }\end{array}$ & Median & $\begin{array}{c}\text { 90th } \\
\text { percentile }\end{array}$ \\
\hline Gettysburg Lowland & 39 & 34.0 & 146 & 248 \\
\hline Diabase (Trd) & 1 & -- & 105 & -- \\
\hline Gettysburg Formation (Trg) & 14 & 133 & 175 & 270 \\
\hline Gettysburg Conglomerate ( $\operatorname{Trgc})$ & 9 & 14.0 & 80.0 & 212 \\
\hline New Oxford Formation (Trn) & 15 & 34.0 & 143 & 194 \\
\hline Blue Ridge & 12 & 11.4 & 43.1 & 95.0 \\
\hline Metarhyolite (mr) & 7 & 11.4 & 36.2 & 95.0 \\
\hline Greenstone Schist (vs) & 5 & 11.4 & 65.0 & 115 \\
\hline Piedmont Lowland & 5 & 72.0 & 158 & 323 \\
\hline Conestoga Formation (OCc) & 1 & -- & 102 & -- \\
\hline Ledger Formation $(\mathrm{Cl})$ & 1 & -- & 158 & -- \\
\hline Kinzers Formation (Ck) & 2 & 175 & 249 & 323 \\
\hline Vintage Formation $(\mathrm{Cv})$ & 1 & -- & 72.0 & -- \\
\hline Piedmont Upland & 7 & 15.0 & 32.0 & 120 \\
\hline Harpers Formation (Ch) & 1 & -- & 15.0 & -- \\
\hline Marburg Schist (Xwm) & 6 & 23.9 & 32.9 & 120 \\
\hline
\end{tabular}

Table 13. Field measurements of hardness in ground water from Adams County, Pennsylvania, by hydrogeologic unit and geologic formation

[--, insufficient data available]

\begin{tabular}{lrrrr}
\hline \multirow{2}{*}{$\begin{array}{c}\text { Hydrogeologic unit } \\
\text { and geologic formation } \\
\text { (with abbreviation) }\end{array}$} & $\begin{array}{c}\text { Number } \\
\text { of wells }\end{array}$ & \multicolumn{2}{c}{$\begin{array}{c}\text { Field hardness, in milligrams per liter } \\
\text { as calcium carbonate }\end{array}$} \\
\cline { 3 - 6 } & & $\begin{array}{c}10 \text { th } \\
\text { percentile }\end{array}$ & Median & $\begin{array}{c}\text { 90th } \\
\text { percentile }\end{array}$ \\
\hline Gettysburg Lowland & 212 & 85 & 170 & 310 \\
Diabase (Trd) & 36 & 86 & 150 & 290 \\
Gettysburg Formation (Trg) & 100 & 110 & 210 & 320 \\
Gettysburg Conglomerate (Trgc) & 18 & 34 & 89 & 150 \\
New Oxford Formation (Trn) & 58 & 72 & 150 & 340 \\
\hline Blue Ridge & 30 & 17 & 51 & 95 \\
Metabasalt (mb) & 6 & 34 & 86 & 140 \\
Metarhyolite (mr) & 23 & 17 & 51 & 68 \\
Greenstone Schist (vs) & 1 & -- & 34 & -- \\
\hline Piedmont Lowland & 32 & 150 & 260 & 320 \\
Conestoga Formation (OCc) & 23 & 150 & 240 & 310 \\
Ledger Formation (Cl) & 1 & -- & 220 & -- \\
Kinzers Formation (Ck) & 7 & 150 & 270 & 410 \\
Vintage Formation (Cv) & 1 & -- & 270 & -- \\
\hline Piedmont Upland & 17 & 17 & 100 & 240 \\
Antietam Formation (Ca) & 3 & 51 & 85 & 240 \\
Harpers Formation (Ch) & 9 & 17 & 120 & 260 \\
Marburg Schist (Xwm) & 4 & 17 & 43 & 51 \\
Metabasalt (mb) & 1 & -- & 100 & -- \\
\hline
\end{tabular}


silica, calcium, chloride, sodium, magnesium, nitrate, potassium, and fluoride. These major ions commonly are used to describe the general chemical type of water contained in a particular hydrogeologic unit or formation. Because of the wide time frame involved (1950-96) and objectives of different projects, in which all or part of Adams County was included, detection limits and methods of analysis varied for the major ions. Analyses with a reporting value of 0.00 were retained as 0.00 . Where major ion concentrations were below the detection limit, an artificial concentration was generated by multiplying the detection limit by 0.5 . For example, if a laboratory analysis resulting in a concentration for a constituent of less than $10(<10)$, concentration of that constituent was set to an artificial value of 5 . If a well was sampled more than one time for the same constituent, the resulting concentrations were summed, and the average was retained for further statistical analysis.
Total dissolved solids is a measure of the total solutes in water. Fresh water contains total dissolved solids of $0-1,000 \mathrm{mg} / \mathrm{L}$; slightly saline water contains total dissolved solids of $1,000-$ 3,000 mg/L (Robinove and others, 1958). The USEPA SMCL for total dissolved solids in drinking water is $500 \mathrm{mg} / \mathrm{L}$. Rocks that are rich in quartz, which is resistant to weathering, contain the lowest concentrations of total dissolved solids (table 14). Hydrogeologic units or formations that contain more easily erodible rocks such as limestone, siltstone, and shale generally have the highest concentrations of total dissolved solids.

Concentrations of total dissolved solids in water from 7 of 34 wells sampled for this constituent exceeded the SMCL. Four of the seven wells that exceeded the SMCL are completed in the New Oxford Formation, two in the Gettysburg Formation, and one in the Kinzers Formation.

Table 14. Total dissolved solids in ground water from Adams County, Pennsylvania, by hydrogeologic unit and geologic formation

\begin{tabular}{crrrr} 
[--, insufficient data available] & \multicolumn{5}{c}{$\begin{array}{c}\text { Total dissolved solids, } \\
\text { in milligrams per liter }\end{array}$} \\
\hline $\begin{array}{c}\text { Hydrogeologic unit } \\
\text { and geologic formation } \\
\text { (with abbreviation) }\end{array}$ & $\begin{array}{c}\text { Number } \\
\text { of wells }\end{array}$ & $\begin{array}{c}\text { 10th } \\
\text { percentile }\end{array}$ & Median & $\begin{array}{c}\text { 90th } \\
\text { percentile }\end{array}$ \\
\cline { 3 - 6 } Gettysburg Lowland & 27 & 67 & 270 & 1,020 \\
Diabase (Trd) & 2 & 213 & 214 & 215 \\
Gettysburg Formation (Trg) & 12 & 237 & 319 & 542 \\
Gettysburg Conglomerate (Trgc) & 1 & -- & 107 & -- \\
New Oxford Formation (Trn) & 12 & 150 & 248 & 683 \\
\hline Piedmont Lowland & 5 & 141 & 291 & 653 \\
Conestoga Formation (OCc) & 1 & -- & 178 & -- \\
Ledger Formation (Cl) & 1 & -- & 291 & -- \\
Kinzers Formation (Ck) & 2 & 308 & 481 & 653 \\
Vintage Formation (Cv) & 1 & -- & 141 & -- \\
\hline Piedmont Upland & 2 & 55 & 85 & 115 \\
Harpers Formation (Ch) & 1 & -- & 115 & -- \\
Marburg Schist (mb) & 1 & -- & 55 & -- \\
\hline
\end{tabular}


Calcium and magnesium are dissolved from practically all rocks and soils, especially from limestone, dolomite, and gypsum. Calcium and magnesium are the cause of most hardness and, in combination with bicarbonate, are the cause of scale formation in steam boilers, water heaters, and pipes. Water low in calcium and magnesium is desired in electroplating, tanning, dyeing, and textile manufacturing. Typical concentrations of calcium and magnesium in ground water range from 5 to $500 \mathrm{mg} / \mathrm{L}$ and 1 to $50 \mathrm{mg} / \mathrm{L}$, respectively (Cook and Miles, 1980, p. 14 and 30). In Adams County, the highest median concentrations of dissolved calcium and magnesium are in ground water from the Piedmont Lowland $(60 \mathrm{mg} / \mathrm{L})$ and the Gettysburg Lowland (14 mg/L), respectively (table 15).

Sodium and potassium are dissolved from practically all rocks and soils. Major sources of sodium and potassium in ground water include salt used for deicing highways, sewage, and industrial wastes. Sodium can be withdrawn from clays and shale layers after long-term groundwater withdrawals and water-level declines alter water-circulation patterns. Sodium concentrations of less than $50 \mathrm{mg} / \mathrm{L}$ have little effect on the usefulness of water for most purposes. Median concentrations of sodium $(14 \mathrm{mg} / \mathrm{L})$ in water from

Table 15. Dissolved calcium and magnesium in ground water from Adams County, Pennsylvania, by hydrogeologic unit and geologic formation [--, insufficient data available]

\begin{tabular}{|c|c|c|c|c|}
\hline \multirow{2}{*}{$\begin{array}{l}\text { Hydrogeologic unit } \\
\text { and geologic formation } \\
\text { (with abbreviation) }\end{array}$} & \multirow{2}{*}{$\begin{array}{l}\text { Number } \\
\text { of wells }\end{array}$} & \multicolumn{3}{|c|}{ Concentration, in milligrams per liter } \\
\hline & & $\begin{array}{c}\text { 10th } \\
\text { percentile }\end{array}$ & Median & $\begin{array}{c}\text { 90th } \\
\text { percentile }\end{array}$ \\
\hline \multicolumn{5}{|c|}{$\underline{\text { Calcium }}$} \\
\hline Gettysburg Lowland & 50 & 23 & 52 & 89 \\
\hline Diabase (Trd) & 6 & 26 & 31 & 69 \\
\hline Gettysburg Formation (Trg) & 25 & 43 & 60 & 110 \\
\hline Gettysburg Conglomerate ( $\operatorname{Trgc})$ & 3 & 22 & 36 & 38 \\
\hline New Oxford Formation (Trn) & 16 & 20 & 42 & 90 \\
\hline Piedmont Lowland & 6 & 24 & 60 & 100 \\
\hline Conestoga Formation (OCc) & 2 & 38 & 53 & 68 \\
\hline Ledger Formation $(\mathrm{Cl})$ & 1 & -- & 73 & -- \\
\hline Kinzers Formation $(\mathrm{Ck})$ & 2 & 52 & 76 & 100 \\
\hline Vintage Formation $(\mathrm{Cv})$ & 1 & -- & 24 & -- \\
\hline Piedmont Upland & 4 & 3.6 & 13 & 76 \\
\hline Harpers Formation (Ch) & 2 & 8.6 & 42 & 76 \\
\hline Marburg Schist (Xwm) & 1 & -- & 3.6 & -- \\
\hline Metabasalt (mb) & 1 & -- & 18 & -- \\
\hline \multicolumn{5}{|c|}{ Magnesium } \\
\hline Gettysburg Lowland & 50 & 7.6 & 14 & 32 \\
\hline Diabase (Trd) & 6 & 14 & 16 & 22 \\
\hline Gettysburg Formation (Trg) & 25 & 7.9 & 15 & 31 \\
\hline Gettysburg Conglomerate ( $\operatorname{Trgc})$ & 3 & 7.0 & 8.1 & 12 \\
\hline New Oxford Formation (Trn) & 16 & 7.4 & 12 & 55 \\
\hline Piedmont Lowland & 6 & 6.8 & 11 & 42 \\
\hline Conestoga Formation (OCc) & 2 & 9.4 & 11 & 12 \\
\hline Ledger Formation $(\mathrm{Cl})$ & 1 & -- & 3.4 & -- \\
\hline Kinzers Formation $(\mathrm{Ck})$ & 2 & 21 & 33 & 44 \\
\hline Vintage Formation $(\mathrm{Cv})$ & 1 & -- & 4.2 & -- \\
\hline Piedmont Upland & 4 & 3.2 & 5.4 & 10 \\
\hline Harpers Formation (Ch) & 2 & 4.8 & 7.4 & 10 \\
\hline Marburg Schist (Xwm) & 1 & -- & 3.2 & -- \\
\hline Metabasalt (mb) & 1 & -- & 6.0 & -- \\
\hline
\end{tabular}


wells drilled in the Gettysburg and New Oxford Formations were greater than median concentration in the other hydrogeologic units or geologic formations (table 16). Potassium concentrations greater than a few tens of milligrams per liter are unusual (Hem, 1985). Median concentrations of potassium in well water are lowest for the Gettysburg Conglomerate, diabase, and metabasalt (table 16).

The most important natural sources of chloride are the sedimentary rocks, especially evaporates; fine-grained marine shales might retain chloride for considerable amounts of time. Anthropogenic effects, such as input from sewage and industrial wastes, fertilizers, and highway deicing salt, can introduce large amounts of chloride to ground water. Water with less than $150 \mathrm{mg} / \mathrm{L}$ chloride is satisfactory for most purposes. A chloride content of more than $250 \mathrm{mg} / \mathrm{L}$ is generally objectionable for public supply and exceeds the USEPA SMCL. Water containing $500 \mathrm{mg} / \mathrm{L}$ or more of chloride generally has a disagreeable taste. Three wells contain water that exceeds the USEPA SMCL; all three are drilled in the Marburg Schist and are located at the Keystone Landfill (also known as the Keystone Sanitation Superfund Site), southeast of Littlestown (table 17).

Table 16. Dissolved sodium and potassium in ground water from Adams County, Pennsylvania, by hydrogeologic unit and geologic formation

[--, insufficient data available]

\begin{tabular}{|c|c|c|c|c|}
\hline \multirow{2}{*}{$\begin{array}{l}\text { Hydrogeologic unit } \\
\text { and geologic formation } \\
\text { (with abbreviation) }\end{array}$} & \multirow{2}{*}{$\begin{array}{l}\text { Number } \\
\text { of wells }\end{array}$} & \multicolumn{3}{|c|}{ Concentration, in milligrams per liter } \\
\hline & & $\begin{array}{c}\text { 10th } \\
\text { percentile }\end{array}$ & Median & $\begin{array}{c}\text { 90th } \\
\text { percentile }\end{array}$ \\
\hline \multicolumn{5}{|c|}{$\underline{\text { Sodium }}$} \\
\hline Gettysburg Lowland & 48 & 4.9 & 13 & 27 \\
\hline Diabase (Trd) & 6 & 3.8 & 5.4 & 8.0 \\
\hline Gettysburg Formation (Trg) & 25 & 7.6 & 14 & 27 \\
\hline Gettysburg Conglomerate ( $\operatorname{Trgc})$ & 3 & 3.3 & 4.9 & 19 \\
\hline New Oxford Formation (Trn) & 14 & 7.4 & 14 & 34 \\
\hline Piedmont Lowland & 6 & 3.4 & 8.1 & 44 \\
\hline Conestoga Formation (OCc) & 2 & 3.8 & 7.9 & 12 \\
\hline Ledger Formation $(\mathrm{Cl})$ & 1 & -- & .6 & -- \\
\hline Kinzers Formation (Ck) & 2 & 1.1 & 1.6 & 2.0 \\
\hline Vintage Formation (Cv) & 1 & -- & 2.0 & -- \\
\hline Piedmont Upland & 4 & 1.4 & 7.8 & 21 \\
\hline Harpers Formation (Ch) & 2 & .4 & .8 & 1.2 \\
\hline Marburg Schist (Xwm) & 1 & -- & 1.4 & -- \\
\hline Metabasalt (mb) & 1 & -- & 3.6 & -- \\
\hline \multicolumn{5}{|c|}{ Potassium } \\
\hline Gettysburg Lowland & 48 & .4 & 1.0 & 3.8 \\
\hline Diabase (Trd) & 6 & .3 & .5 & 1.0 \\
\hline Gettysburg Formation (Trg) & 25 & .5 & 1.0 & 3.0 \\
\hline Gettysburg Conglomerate ( $\operatorname{Trgc})$ & 3 & .3 & .5 & 1.3 \\
\hline New Oxford Formation (Trn) & 14 & .4 & 1.2 & 4.2 \\
\hline Piedmont Lowland & 6 & .6 & 1.5 & 2.0 \\
\hline Conestoga Formation (OCc) & 2 & 1.0 & 1.4 & 1.8 \\
\hline Ledger Formation $(\mathrm{Cl})$ & 1 & -- & .6 & -- \\
\hline Kinzers Formation (Ck) & 2 & 1.1 & 1.6 & 2.0 \\
\hline Vintage Formation $(\mathrm{Cv})$ & 1 & -- & 2.0 & -- \\
\hline Piedmont Upland & 3 & .3 & .4 & 1.2 \\
\hline Harpers Formation $(\mathrm{Ch})$ & 2 & .4 & .8 & 1.2 \\
\hline Metabasalt (mb) & 1 & -- & .3 & -- \\
\hline
\end{tabular}


Table 17. Dissolved chloride in ground water from Adams County, Pennsylvania, by hydrogeologic unit and geologic formation

[--, insufficient data available]

\begin{tabular}{lcccc}
\hline $\begin{array}{c}\text { Hydrogeologic unit } \\
\text { and geologic formation } \\
\text { (with abbreviations) }\end{array}$ & $\begin{array}{c}\text { Number } \\
\text { of wells }\end{array}$ & \multicolumn{2}{c}{$\begin{array}{c}\text { Dissolved chloride, } \\
\text { in milligrams per liter }\end{array}$} \\
\cline { 3 - 6 } & & $\begin{array}{c}10 \text { th } \\
\text { percentile }\end{array}$ & Median & $\begin{array}{c}\text { 90th } \\
\text { percentile }\end{array}$ \\
\hline Gettysburg Lowland & 83 & 4.2 & 16 & 66 \\
Diabase (Trd) & 5 & 2.9 & 11 & 15 \\
Gettysburg Formation (Trg) & 49 & 4.8 & 18 & 66 \\
Gettysburg Conglomerate (Trgc) & 11 & 4.2 & 19 & 23 \\
New Oxford Formation (Trn) & 18 & 4.0 & 11 & 100 \\
\hline Blue Ridge & 12 & 1.9 & 11 & 45 \\
Metarhyolite (mr) & 7 & 1.7 & 13 & 92 \\
Greenstone Schist (vs) & 5 & 2.5 & 10 & 40 \\
\hline Piedmont Lowland & 6 & 6.9 & 25 & 120 \\
Conestoga Formation (OCc) & 2 & 9.0 & 19 & 29 \\
Ledger Formation (Cl) & 1 & -- & 21 & -- \\
Kinzers Formation (Ck) & 2 & 32 & 76 & 120 \\
Vintage Formation (Cv) & 1 & -- & 6.9 & -- \\
\hline Piedmont Upland & 9 & 1.6 & 35 & 810 \\
Harpers Formation (Ch) & 2 & 26 & 34 & 42 \\
Marburg Schist (Xwm) & 6 & 1.6 & 37 & 810 \\
Metabasalt (mb) & 1 & -- & 6.0 & -- \\
\hline
\end{tabular}


Sulfate $\left(\mathrm{SO}_{4}\right)$ is a common constituent of ground water. Major sources of sulfate are soils and sedimentary rocks that contain gypsum $\left(\mathrm{CaSO}_{4} \cdot 2 \mathrm{H}_{2} \mathrm{O}\right)$ or anhydrite $\left(\mathrm{CaSO}_{4}\right)$ and igneous or volcanic rocks that contain iron sulfides such as pyrite $\left(\mathrm{FeS}_{2}\right)$ and other sulfur compounds. Sulfate is commonly present in some industrial wastes and sewage and is produced in the combustion of fuels and smelting of ore. Wood (1980, p. 52) suggested that if a water sample contained elevated concentrations of sulfate, and that human sources of sulfate could be ruled out, the water was relatively old and had been in contact with the enclosing rock for a considerable amount of time. The Gettysburg Formation contains water with the highest median concentration of sulfate (table 18). It also contains five of six wells that exceed the USEPA SMCL of $250 \mathrm{mg} / \mathrm{L}$. Two of the five wells contain water with sulfate concentrations greater than the USEPA MCL of $500 \mathrm{mg} / \mathrm{L}$. One well in the Marburg Schist contained water with a sulfate concentration of $580 \mathrm{mg} / \mathrm{L}$. Typical sulfate concentrations in ground water range from 0.05 to $10 \mathrm{mg} / \mathrm{L}$ (Cook and Miles, 1980, p. 51).

Fluoride and silica are dissolved from practically all rocks and soils. Fluorite $\left(\mathrm{CaF}_{2}\right)$ and apatite $\left[\mathrm{Ca}_{5}(\mathrm{Cl}, \mathrm{F}, \mathrm{OH})\left(\mathrm{PO}_{4}\right)_{3}\right]$ are common fluoride minerals. Silica is a major constituent in igneous rocks and as quartz grains in sandstones. None of the 55 wells sampled contained water that exceeded the USEPA SMCL of $2 \mathrm{mg} / \mathrm{L}$ for fluoride (table 19). No SMCL or MCL has been established for silica in ground water. Ground water from the diabase has the highest median concentration of silica (table 19). Typically, the concentration of silica in ground water ranges from 1 to about $30 \mathrm{mg} / \mathrm{L}$ (Hem, 1985, p. 73).

Table 18. Dissolved sulfate in ground water from Adams County, Pennsylvania, by hydrogeologic unit and geologic formation

[--, insufficient data available]

\begin{tabular}{ccccc}
\hline $\begin{array}{c}\text { Hydrogeologic unit } \\
\text { and geologic formation } \\
\text { (with abbreviation) }\end{array}$ & $\begin{array}{c}\text { Number } \\
\text { of wells }\end{array}$ & \multicolumn{3}{c}{$\begin{array}{c}\text { Dissolved sulfate, } \\
\text { in milligrams per liter }\end{array}$} \\
\cline { 3 - 6 } & & $\begin{array}{c}10 \text { th } \\
\text { percentile }\end{array}$ & Median & $\begin{array}{c}\text { 90th } \\
\text { percentile }\end{array}$ \\
\hline Gettysburg Lowland & 83 & 2.5 & 31 & 83 \\
Diabase (Trd) & 5 & 10 & 23 & 44 \\
Gettysburg Formation (Trg) & 48 & 17 & 44 & 182 \\
Gettysburg Conglomerate (Trgc) & 10 & 0.0 & 2.7 & 28 \\
New Oxford Formation (Trn) & 20 & 2.5 & 25 & 97 \\
\hline Blue Ridge & 12 & 11 & 18 & 26 \\
Metarhyolite (mr) & 7 & 5.5 & 17 & 19 \\
Greenstone Schist (vs) & 5 & 14 & 23 & 26 \\
\hline Piedmont Lowland & 6 & 8.1 & 18 & 31 \\
Conestoga Formation (OCc) & 2 & 8.1 & 15 & 21 \\
Ledger Formation (Cl) & 1 & -- & 15 & -- \\
Kinzers Formation (Ck) & 2 & 13 & 22 & 31 \\
Vintage Formation (Cv) & 1 & -- & 25 & -- \\
\hline Piedmont Upland & 9 & 1.1 & 4.7 & 50 \\
Harpers Formation (Ch) & 2 & 3.9 & 27 & 50 \\
Marburg Schist (Xwm) & 6 & 1.1 & 7.0 & 29 \\
Metabasalt (mb) & 1 & -- & 2.5 & -- \\
\hline
\end{tabular}


Table 19. Dissolved fluoride and silica in ground water from Adams County, Pennsylvania, by hydrogeologic unit and geologic formation

[--, insufficient data available]

\begin{tabular}{|c|c|c|c|c|}
\hline \multirow{2}{*}{$\begin{array}{l}\text { Hydrogeologic unit } \\
\text { and geologic formation } \\
\text { (with abbreviation) }\end{array}$} & \multirow{2}{*}{$\begin{array}{l}\text { Number } \\
\text { of wells }\end{array}$} & \multicolumn{3}{|c|}{ Concentration, in milligrams per liter } \\
\hline & & $\begin{array}{c}\text { 10th } \\
\text { percentile }\end{array}$ & Median & $\begin{array}{c}\text { 90th } \\
\text { percentile }\end{array}$ \\
\hline \multicolumn{5}{|c|}{$\underline{\text { Fluoride }}$} \\
\hline Gettysburg Lowland & 45 & 0.05 & 0.05 & 0.30 \\
\hline Diabase (Trd) & 5 & .05 & .05 & .10 \\
\hline Gettysburg Formation (Trg) & 23 & .05 & .10 & .30 \\
\hline Gettysburg Conglomerate ( $\operatorname{Trgc})$ & 3 & .05 & .19 & .30 \\
\hline New Oxford Formation (Trn) & 14 & .00 & .05 & .30 \\
\hline Piedmont Lowland & 6 & .00 & .03 & .10 \\
\hline Conestoga Formation (OCc) & 2 & .10 & .10 & .10 \\
\hline Ledger Formation (Cl) & 1 & -- & .00 & -- \\
\hline Kinzers Formation (Ck) & 2 & .00 & .00 & .00 \\
\hline Vintage Formation $(\mathrm{Cv})$ & 1 & -- & .00 & -- \\
\hline Piedmont Upland & 4 & .10 & .20 & .20 \\
\hline Harpers Formation (Ch) & 2 & .20 & .20 & .20 \\
\hline Marburg Schist (Xwm) & 1 & -- & .20 & -- \\
\hline Metabasalt $(\mathrm{mb})$ & 1 & -- & .10 & -- \\
\hline \multicolumn{5}{|c|}{ Silica } \\
\hline Gettysburg Lowland & 36 & 14 & 22 & 51 \\
\hline Diabase (Trd) & 5 & 46 & 53 & 65 \\
\hline Gettysburg Formation (Trg) & 19 & 14 & 23 & 38 \\
\hline Gettysburg Conglomerate ( $\operatorname{Trgc})$ & 1 & -- & 19 & -- \\
\hline New Oxford Formation (Trn) & 11 & 13 & 20 & 23 \\
\hline Piedmont Lowland & 5 & 7.1 & 11 & 14 \\
\hline Conestoga Formation (OCc) & 1 & -- & 8.9 & -- \\
\hline Ledger Formation $(\mathrm{Cl})$ & 1 & -- & 11 & -- \\
\hline Kinzers Formation (Ck) & 2 & 7.1 & 9.1 & 11 \\
\hline Vintage Formation $(\mathrm{Cv})$ & 1 & -- & 14 & -- \\
\hline Piedmont Upland & 2 & 7.8 & 8.0 & 8.1 \\
\hline Harpers Formation (Ch) & 1 & -- & 7.8 & -- \\
\hline Metabasalt (mb) & 1 & -- & 8.1 & -- \\
\hline
\end{tabular}




\section{Nutrients}

Nitrogen and phosphorus species are essential nutrients for plant and animal growth. Nitrogen is present in water principally as nitrate $\left(\mathrm{NO}_{3}\right)$, nitrite $\left(\mathrm{NO}_{2}\right)$, and ammonia $\left(\mathrm{NH}_{4}\right)$. Nitrate is the most common nitrogen species in ground water. Small concentrations of nitrate do not effect the usefulness of water. Most ground water contains less than $2 \mathrm{mg} / \mathrm{L}$ nitrate. Waters containing more than $10 \mathrm{mg} / \mathrm{L}$ (USEPA MCL) nitrate may cause methemoglobinemia ("blue-baby syndrome," a disease often fatal in infants) and, therefore, should not be used in infant feeding. Decaying organic matter, animal waste, sewage, septic tanks, and fertilizers are principal nutrient sources. Phosphorus is also a common element in igneous and sedimentary rocks. The major form of phosphorus dissolved in ground water is orthophosphate. If additional phosphorus is attached to sediment suspended in ground water, it is analyzed and reported as total phosphorus.

The concentrations of nitrate, nitrite, and phosphorus for each hydrogeologic unit and geologic formation are summarized in tables 20 and 21. The locations of the wells sampled for these nutrients are shown in figure 6 . These data are difficult to evaluate statistically because the sample population is small and concentrations for nitrite and phosphorus commonly are below detection limits. Median concentrations of nitrate are greatest in ground water from the Gettysburg, New Oxford, Conestoga, and Kinzers Formations (table 20). These four formations generally underlie broad valleys and have well drained or rich soils, making them suitable for intensive farming and fertilization. The water in 9 of 64 wells sampled for nitrate contained dissolved nitrate (as $\mathrm{N})$ concentrations greater than the USEPA MCL. Four of the nine wells are located in the New Oxford Formation, four in the metarhyolite, and one in the greenstone schist. All four of the wells in the New Oxford Formation that have nitrate concentrations above the MCL are less than $100 \mathrm{ft}$ deep, which suggests contaminated ground water is seeping into the wells. Depths of the other five wells with elevated nitrate concentrations are not known; however, they are located in or adjacent to orchards.

Median concentrations of nitrite (as N) in all the hydrogeologic units and geologic formations are at or below the most commonly used detection level of $0.01 \mathrm{mg} / \mathrm{L}$ (table 20). Three wells contained water with nitrite concentrations greater than the USEPA MCL of $1.0 \mathrm{mg} / \mathrm{L}$. The three wells, all drilled in the Gettysburg Conglomerate, are located northeast of Biglerville in an area with numerous orchards. Excessive fertilization may be the source of the dissolved nitrites in these three wells.

The median concentrations of dissolved orthophosphate and total phosphorus in ground water of Adams County are less than $0.10 \mathrm{mg} / \mathrm{L}$ (table 21). Concentrations of phosphorus in ground water that exceed a few tenths of a milligram per liter are usually the result of human activities (Hem, 1985, p. 126-129). One well and a tile drain contained water with concentrations of total phosphorus greater than $1 \mathrm{mg} / \mathrm{L}$. The well and the drain are in the New Oxford Formation in an area of intensive hog production. Hog manure in this area has been reported to seep into streams and ground water (Langland and Fishel, 1996).

\section{Selected Metals and Other Trace Constituents}

Metals and other trace constituents, such as lead and arsenic, typically are present in low concentrations (less than $1 \mathrm{mg} / \mathrm{L}$ ) in water from wells in Adams County. Most metals and other trace constituents in ground water are leached from the soil or dissolved from the underlying bedrock in minute quantities by circulating ground water. Atmospheric deposition of metals such as lead has been documented in surface water (Chow and Earl, 1970; Durum and others, 1971) and may contribute to increased metal concentration in ground water. Copper, lead, and zinc in tap water may be leached from household plumbing systems by corrosive ground water.

Langland and Dugas (1995) showed that significant relations exist between the corrosion index and rock type. In Adams County, ground water from the crystalline rocks of the Piedmont Upland and crystalline and quartzite rocks of the Blue Ridge have greater corrosion potential than ground water from the other hydrogeologic units. Ground waters of the Piedmont Upland are potentially corrosive because they are slightly acidic and have low concentrations of calcium, low alkalinity, and low specific conductance. Ground water from the Gettysburg Formation and the carbonate rocks of the Piedmont Lowland is noncorrosive and may precipitate calcium carbonate. 
Table 20. Dissolved nitrate and nitrite (as $N$ ) in ground water from Adams County, Pennsylvania, by hydrogeologic unit and geologic formation

[--, insufficient data available]

\begin{tabular}{|c|c|c|c|c|}
\hline \multirow{2}{*}{$\begin{array}{l}\text { Hydrogeologic unit } \\
\text { and geologic formation } \\
\text { (with abbreviation) }\end{array}$} & \multirow{2}{*}{$\begin{array}{l}\text { Number } \\
\text { of wells }\end{array}$} & \multicolumn{3}{|c|}{ Concentration, in milligrams per liter (as $\mathrm{N}$ ) } \\
\hline & & $\begin{array}{c}\text { 10th } \\
\text { percentile }\end{array}$ & Median & $\begin{array}{c}\text { 90th } \\
\text { percentile }\end{array}$ \\
\hline \multicolumn{5}{|c|}{ Nitrate } \\
\hline Gettysburg Lowland & 43 & 0.50 & 3.1 & 10 \\
\hline Diabase (Trd) & 1 & -- & 1.1 & -- \\
\hline Gettysburg Formation (Trg) & 17 & .50 & 3.1 & 8.2 \\
\hline Gettysburg Conglomerate $(\operatorname{Trgc})$ & 7 & .13 & 1.9 & 4.4 \\
\hline New Oxford Formation (Trn) & 18 & .56 & 3.7 & 22 \\
\hline Blue Ridge & 12 & .28 & 2.0 & 28 \\
\hline Metarhyolite (mr) & 7 & .28 & 2.2 & 29 \\
\hline Greenstone Schist (vs) & 5 & .25 & 1.8 & 28 \\
\hline Piedmont Lowland & 5 & .77 & 3.5 & 9.0 \\
\hline Conestoga Formation (OCc) & 2 & 3.5 & 6.3 & 9.0 \\
\hline Kinzers Formation (Ck) & 2 & 2.7 & 3.6 & 4.5 \\
\hline Vintage Formation $(\mathrm{Cv})$ & 1 & -- & .77 & -- \\
\hline Piedmont Upland & 9 & .02 & 2.1 & 4.3 \\
\hline Harpers Formation (Ch) & 2 & .66 & 1.7 & 2.7 \\
\hline Marburg Schist (Xwm) & 6 & .02 & 2.0 & 4.3 \\
\hline Metabasalt (mb) & 1 & -- & 2.6 & -- \\
\hline \multicolumn{5}{|c|}{ Nitrite } \\
\hline Gettysburg Lowland & 68 & .005 & .005 & .020 \\
\hline Diabase (Trd) & 10 & .005 & .005 & .015 \\
\hline Gettysburg Formation (Trg) & 40 & .005 & .005 & .014 \\
\hline Gettysburg Conglomerate (Trgc) & 11 & .000 & .010 & 1.1 \\
\hline New Oxford Formation (Trn) & 7 & .000 & .005 & .13 \\
\hline Blue Ridge & 8 & .005 & .009 & .040 \\
\hline Metarhyolite (mr) & 4 & .005 & .014 & .040 \\
\hline Greenstone Schist (vs) & 4 & .005 & .008 & .010 \\
\hline Piedmont Lowland & 2 & .005 & .005 & .005 \\
\hline Conestoga Formation (OCc) & 1 & -- & .005 & -- \\
\hline Ledger Formation $(\mathrm{Cl})$ & 1 & -- & .005 & -- \\
\hline Piedmont Upland & 7 & .000 & .005 & .060 \\
\hline Harpers Formation (Ch) & 1 & -- & .005 & -- \\
\hline Marburg Schist (Xwm) & 5 & .000 & .010 & .060 \\
\hline Metabasalt (mb) & 1 & -- & .005 & -- \\
\hline
\end{tabular}


Table 21. Phosphorus as total, dissolved, and orthophosphate in ground water from Adams County, Pennsylvania, by hydrogeologic unit and geologic formation

[--, insufficient data available]

\begin{tabular}{|c|c|c|c|c|}
\hline \multirow{2}{*}{$\begin{array}{l}\text { Hydrogeologic unit } \\
\text { and geologic formation } \\
\text { (with abbreviation) }\end{array}$} & \multirow{2}{*}{$\begin{array}{l}\text { Number } \\
\text { of wells }\end{array}$} & \multicolumn{3}{|c|}{ Concentration, in milligrams per liter } \\
\hline & & $\begin{array}{c}\text { 10th } \\
\text { percentile }\end{array}$ & Median & $\begin{array}{c}\text { 90th } \\
\text { percentile }\end{array}$ \\
\hline \multicolumn{5}{|c|}{ Total phosphorus (as $\mathrm{P}$ ) } \\
\hline Gettysburg Lowland & 5 & 0.020 & 0.060 & 8.5 \\
\hline New Oxford Formation (Trn) & 5 & .020 & .060 & 8.5 \\
\hline Blue Ridge & 4 & .005 & .013 & .030 \\
\hline Metarhyolite (mr) & 3 & .005 & .020 & .030 \\
\hline Greenstone Schist (vs) & 1 & -- & .005 & -- \\
\hline \multicolumn{5}{|c|}{ Dissolved phosphorus (as $\mathrm{P}$ ) } \\
\hline Gettysburg Lowland & 5 & .005 & .005 & .15 \\
\hline Diabase (Trd) & 1 & -- & .005 & -- \\
\hline Gettysburg Formation (Trg) & 3 & .005 & .005 & .020 \\
\hline New Oxford Formation (Trn) & 1 & -- & .15 & -- \\
\hline Piedmont Lowland & 1 & -- & .010 & -- \\
\hline Ledger Formation $(\mathrm{Cl})$ & 1 & -- & .010 & -- \\
\hline \multicolumn{5}{|c|}{ Dissolved orthophosphate (as P) } \\
\hline Gettysburg Lowland & 13 & .005 & .011 & .030 \\
\hline Diabase (Trd) & 2 & .005 & .008 & .010 \\
\hline Gettysburg Formation (Trg) & 9 & .005 & .011 & .030 \\
\hline Gettysburg Conglomerate (Trgc) & 1 & -- & .030 & -- \\
\hline New Oxford Formation (Trn) & 1 & -- & .16 & -- \\
\hline Piedmont Lowland & 4 & .000 & .022 & .033 \\
\hline Ledger Formation $(\mathrm{Cl})$ & 1 & -- & .010 & -- \\
\hline Kinzers Formation (Ck) & 2 & .000 & .017 & .033 \\
\hline Vintage Formation $(\mathrm{Cv})$ & 1 & -- & .033 & -- \\
\hline
\end{tabular}




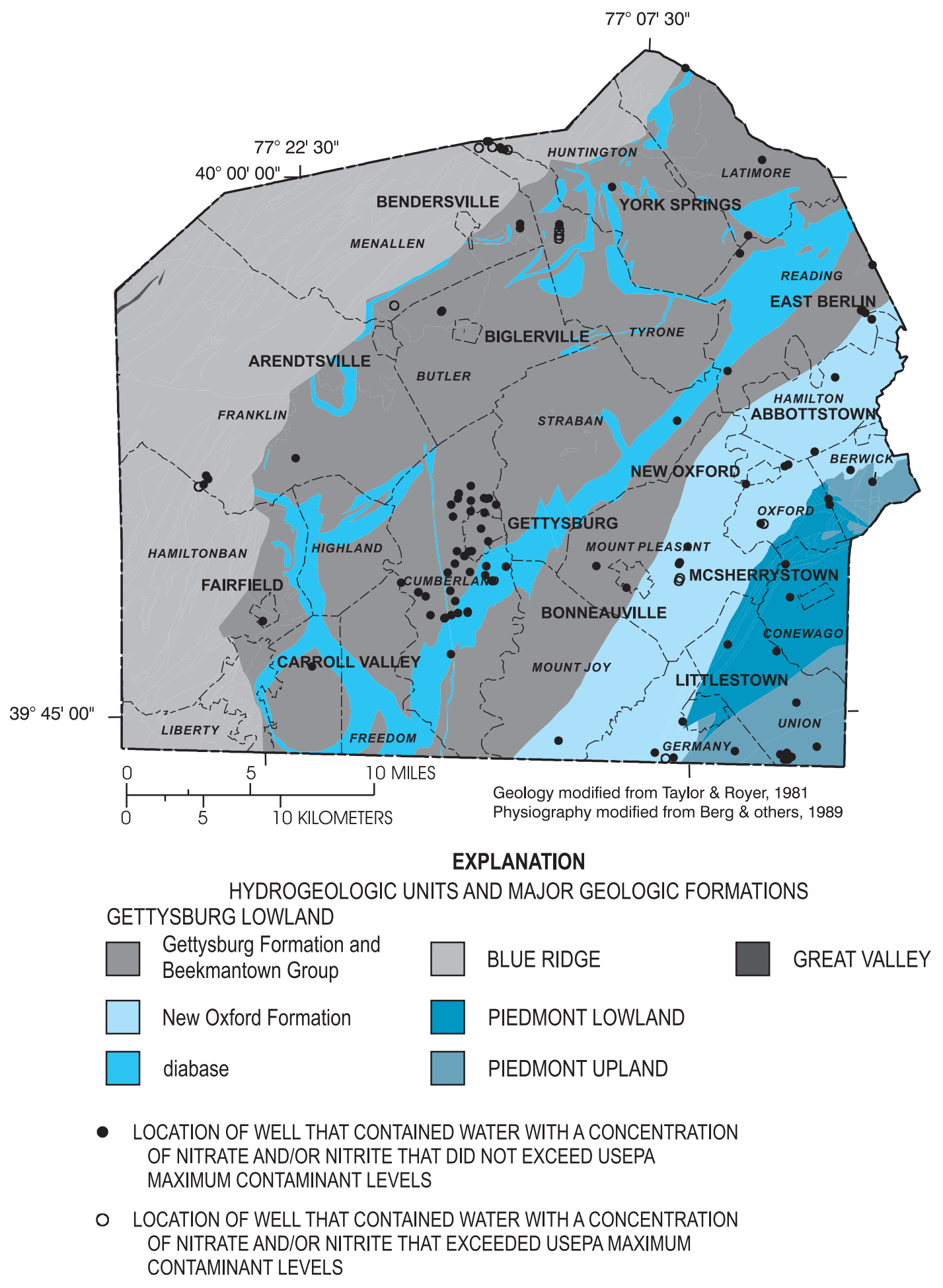

Figure 6. Location of wells in Adams County, Pennsylvania, where ground water was sampled for analyses of nitrate, nitrite, or phosphorus. 
Concentrations of selected metals and other trace constituents in ground water are summarized in tables 22 to 26 . The locations of the wells sampled for minor and trace metals are shown on figure 7. Data for arsenic, cadmium, chromium, copper, and nickel are especially difficult to evaluate statistically because (1) the sample population is small, (2) concentrations are commonly below detection limits, and (3) the laboratory methods used to analyze those metals have multiple detection limits. These trace constituents are not presented in a table but are summarized in the following paragraphs.

Arsenic has been used as a component of pesticides and may enter ground water through waste disposal or agricultural drainage. Because arsenic is highly toxic, even in very small amounts, it is an undesirable impurity (Hem, 1985, p. 144). Arsenic was detected in water samples from 19 of 33 wells for which this constituent was analyzed; the median arsenic concentration was $0.001 \mathrm{mg} / \mathrm{L}$. Arsenic concentrations in the water from 14 wells were below the detection limit of $0.001 \mathrm{mg} / \mathrm{L}$. The highest reported arsenic concentration in the water from the 33 wells was $0.006 \mathrm{mg} / \mathrm{L}$, well below the USEPA MCL of $0.05 \mathrm{mg} / \mathrm{L}$.

Cadmium is present in zinc ore minerals such as sphalerite and is released during the combustion of fossil fuels. It is used in metallugical processes and as an aid in the prevention of corrosion of galvanized pipe. Excessive concentrations are generally the result of contamination by industrial wastes from metal-plating operations. Elevated cadmium concentrations affect the kidneys and can be toxic. Cadmium was detected in the water from 2 of 33 wells for which this constituent was analyzed; the concentrations of cadmium in the water from two wells were $0.001 \mathrm{mg} / \mathrm{L}$. Detection limits for cadmium ranged from a high of less than 0.010 to less than $0.001 \mathrm{mg} / \mathrm{L}$. The USEPA MCL for cadmium is $0.005 \mathrm{mg} / \mathrm{L}$.

Chromium is dissolved from chromiumbearing rocks, generally ultramafics, in minute quantities. It is commonly present in paint pigments and is used in electroplating. Excessive concentrations are generally the result of contamination by industrial wastes. Potential health effects of the ingestion of water with elevated concentrations of chromium include liver, kidney, and circulatory disorders. Chromium was detected in the water from 12 of 32 wells for which this constituent was analyzed. Chromium concentrations in the water from the 12 wells ranged from 0.01 to $0.02 \mathrm{mg} / \mathrm{L}$, well below the USEPA MCL of $0.1 \mathrm{mg} / \mathrm{L}$. Detection limits ranged from less than 0.002 to $0.02 \mathrm{mg} / \mathrm{L}$. The median concentration of chromium in the water of the 32 wells was less than $0.01 \mathrm{mg} / \mathrm{L}$.

The principal sources of copper in ground water include leaching of the native mineral or its metals and ores, acid mine drainage, or organic and inorganic compounds of copper in agricultural pesticide sprays. Copper also may be dissolved from water pipes and plumbing fixtures, especially if the $\mathrm{pH}$ of the water is below 7 (Hem, 1985, p. 141). Copper was detected in the water from 13 of 20 wells for which this constituent was analyzed. Copper concentrations in the water from the 13 wells ranged from 0.004 to $0.07 \mathrm{mg} / \mathrm{L}$, significantly less than the USEPA maximum contaminant level goal (MCLG) of $1.3 \mathrm{mg} / \mathrm{L}$. Detection limits ranged from less than 0.002 to less than $0.02 \mathrm{mg} / \mathrm{L}$. The median concentration of copper in the water of the 20 wells was less than $0.01 \mathrm{mg} / \mathrm{L}$.

Nickel is dissolved from nickel-bearing rocks, which are commonly associated with iron and manganese. Nickel is released from the production of metal alloys, electroplating, batteries, and chemicals. Potential health effects of the ingestion of water containing elevated concentrations of nickel include heart and liver damage. None of the 34 wells for which this constituent was analyzed contained water that exceeded the USEPA MCL of $0.1 \mathrm{mg} / \mathrm{L}$. Detection limits ranged from less than 0.002 to less than $0.1 \mathrm{mg} / \mathrm{L}$; the water from 14 of the wells was analyzed with the highest detection limit of $0.1 \mathrm{mg} / \mathrm{L}$. Typical nickel concentrations in ground water range from 0.001 to $0.05 \mathrm{mg} / \mathrm{L}$ (Cook and Miles, 1980, p. 33).

Aluminum is present in substantial amounts in many igneous and sedimentary rocks, especially clays. The USEPA (1996) has established a SMCL range for aluminum of 0.05 to $0.2 \mathrm{mg} / \mathrm{L}$. Fifteen of the 22 wells for which this constituent was analyzed (table 22) contained water with an aluminum concentration within the USEPA SMCL range. The water in one well completed in the Gettysburg Formation had an aluminum concentration of $0.35 \mathrm{mg} / \mathrm{L}$. Aluminum concentrations in ground water typically range from 0.001 to 


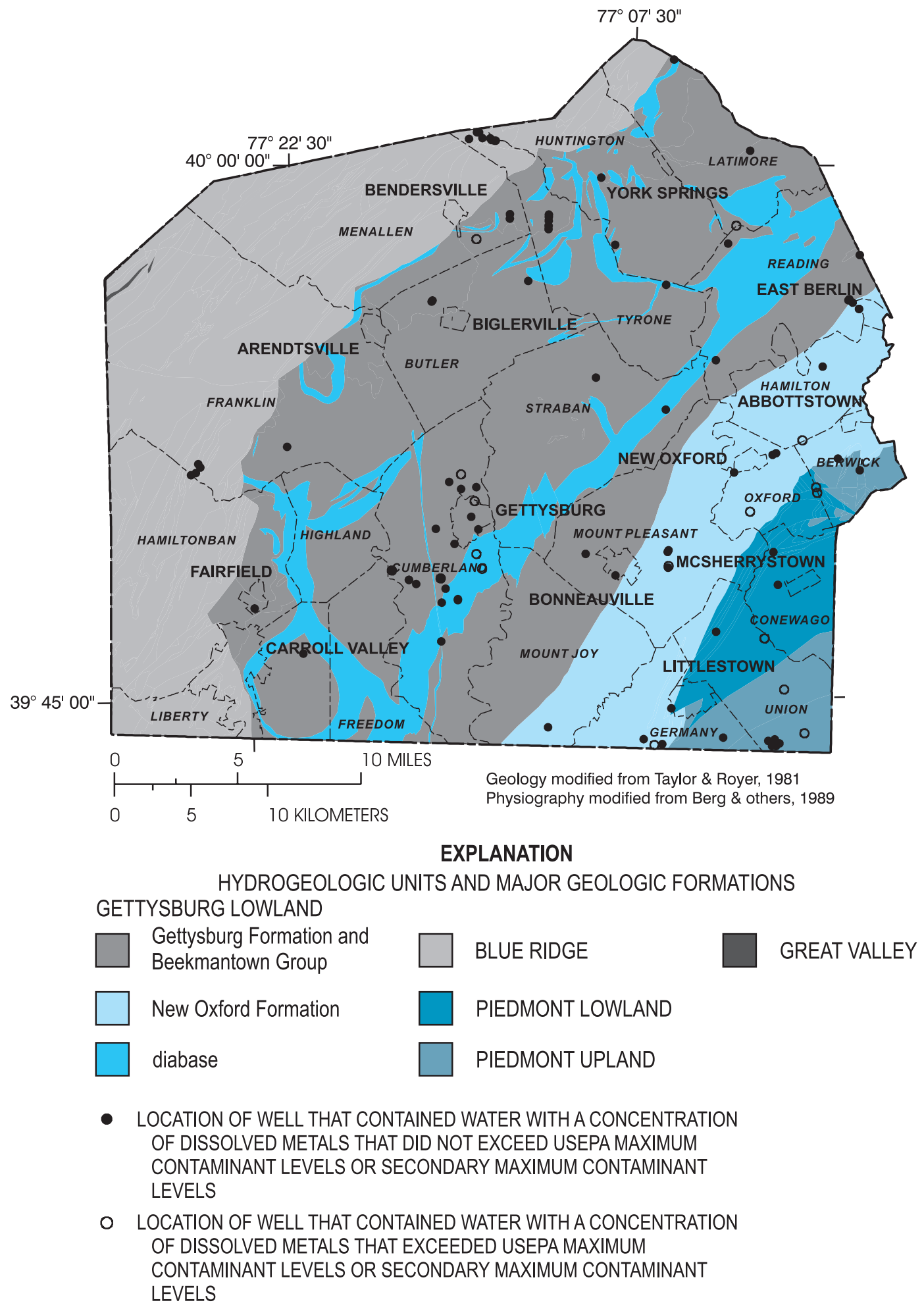

Figure 7. Location of wells in Adams County, Pennsylvania, where ground water was sampled for analysis of minor and trace metals. 
Table 22. Dissolved aluminum in ground water from Adams County, Pennsylvania, by hydrogeologic unit and geologic formation

[--, insufficient data available]

\begin{tabular}{lcccc}
\hline Hydrogeologic unit & & \multicolumn{2}{c}{$\begin{array}{c}\text { Dissolved aluminum, } \\
\text { in milligrams per liter }\end{array}$} \\
$\begin{array}{l}\text { and geologic formation } \\
\text { (with abbreviation) }\end{array}$ & $\begin{array}{c}\text { Number } \\
\text { of wells }\end{array}$ & $\begin{array}{c}\text { 10th } \\
\text { percentile }\end{array}$ & Median & $\begin{array}{c}\text { 90th } \\
\text { percentile }\end{array}$ \\
\hline Gettysburg Lowland & 19 & 0.01 & 0.07 & 0.10 \\
Diabase (Trd) & 2 & .02 & .06 & .10 \\
Gettysburg Formation (Trg) & 11 & .01 & .06 & .10 \\
Gettysburg Conglomerate (Trgc) & 3 & .03 & .07 & .08 \\
New Oxford Formation (Trn) & 3 & .06 & .08 & .08 \\
\hline Piedmont Lowland & 1 & -- & .07 & -- \\
Conestoga Formation (OCc) & 1 & -- & .07 & - \\
\hline Piedmont Upland & 2 & .07 & .08 & .08 \\
Harpers Formation (Ch) & 1 & -- & .08 & -- \\
Metabasalt (mb) & 1 & -- & .07 & - \\
\hline
\end{tabular}

$0.060 \mathrm{mg} / \mathrm{L}$ (Cook and Miles, 1980, p. 5). The exceptions are mostly waters with a $\mathrm{pH}$ below 4.0 (Hem, 1985, p. 73-76).

Iron is dissolved from practically all rocks and soils; iron also is present in organic wastes, plant debris in soils, and coal-mine drainage water. It may also be derived from iron pipes, pumps, and other equipment. On exposure to air, iron in ground water oxidizes to a reddish-brown precipitate. More than about $0.3 \mathrm{mg} / \mathrm{L}$ of iron stains laundry, porcelain, and utensils reddish brown. Elevated concentrations of iron that exceeded the USEPA SMCL of $0.3 \mathrm{mg} / \mathrm{L}$ were present in the water from 12 of the 67 wells for which this constituent was analyzed. Four of the 12 wells that contained water with iron concentrations greater than $0.3 \mathrm{mg} / \mathrm{L}$ are located in the Gettysburg Formation, another 4 are in the New Oxford Formation, and 1 each are in the diabase, Conestoga Formation, Vintage Formation, and the Harpers Formation (table 23). Rock cuttings from wells drilled in the Gettysburg, New Oxford, and Conestoga Formations commonly contain pyrite, which may be a source for much of the dissolved iron in these three formations.

Some principal sources of lead in ground water are combustion of leaded gasoline, smelting of ores, and burning coal. Other lead sources include brass alloy faucets, plumbing, and solder. Water with $\mathrm{pH}$ below 7.0 or water that is poorly buffered may dissolve considerable amounts of lead from pipes and solders. Lead is accumulated by the body and affects the kidneys and causes nervous system damage; excessive concentrations can cause sickness or death. The USEPA (1996) has set a MCLG of 0.0 and an action level of $0.015 \mathrm{mg} /$ $\mathrm{L}$ for lead at the tap. Only 2 of the 33 wells for which this constituent was analyzed contained water with lead concentrations greater than $0.015 \mathrm{mg} / \mathrm{L}$ (table 24). One is located in the Kinzers Formation; the other is in the Gettysburg Formation. However, the detection level for analysis of water from two other wells (located in the diabase) was $0.1 \mathrm{mg} / \mathrm{L}$, well above the USEPA action level.

Manganese is dissolved from many rocks and soils. It is commonly associated with iron in ground water but is not as common as iron. Manganese has the same undesirable characteristics as iron but is more difficult to remove. Ten of 68 wells for which this constituent was analyzed contained water that exceeded the USEPA SMCL of $0.05 \mathrm{mg} / \mathrm{L}$. Half of the 10 wells containing water with elevated concentrations of manganese are located in the Gettysburg Formation, 2 are in the New Oxford Formation, and 1 each in the Vintage Formation, Harpers Formation, and Marburg Schist (table 25). The water in 1 of these 10 wells also contained concentrations of lead and iron that exceeded their respective USEPA-established MCL's. 
Table 23. Dissolved iron in ground water from Adams County, Pennsylvania, by hydrogeologic unit and geologic formation

[--, insufficient data available]

\begin{tabular}{lcccc}
\hline \multirow{2}{*}{$\begin{array}{c}\text { Hydrogeologic unit } \\
\text { and geologic formation } \\
\text { (with abbreviation) }\end{array}$} & $\begin{array}{c}\text { Number } \\
\text { of wells }\end{array}$ & \multicolumn{3}{c}{$\begin{array}{c}\text { Dissolved iron, } \\
\text { in milligrams per liter }\end{array}$} \\
\cline { 3 - 6 } & & $\begin{array}{c}10 \text { th } \\
\text { percentile }\end{array}$ & Median & $\begin{array}{c}\text { 90th } \\
\text { percentile }\end{array}$ \\
\hline Gettysburg Lowland & 57 & 0.005 & 0.060 & 0.53 \\
Diabase (Trd) & 8 & .002 & .050 & .82 \\
Gettysburg Formation (Trg) & 31 & .015 & .063 & .24 \\
Gettysburg Conglomerate (Trgc) & 2 & .040 & .050 & .060 \\
New Oxford Formation (Trn) & 16 & .030 & .11 & 1.2 \\
\hline Piedmont Lowland & 6 & .002 & .055 & 1.6 \\
Conestoga Formation (OCc) & 2 & .070 & .84 & 1.6 \\
Ledger Formation (Cl) & 1 & -- & .002 & -- \\
Kinzers Formation (Ck) & 2 & .030 & .035 & .040 \\
Vintage Formation (Cv) & 1 & -- & .55 & -- \\
\hline Piedmont Upland & 4 & .060 & .27 & .46 \\
Harpers Formation (Ch) & 2 & .25 & .36 & .46 \\
Marburg Schist (Xwm) & 1 & -- & .28 & - \\
Metabasalt (mb) & 1 & -- & .060 & - \\
\hline
\end{tabular}

Table 24. Dissolved lead in ground water from Adams County, Pennsylvania, by hydrogeologic unit and geologic formation

[--, insufficient data available]

\begin{tabular}{lrcrcc}
\hline \multirow{2}{*}{$\begin{array}{c}\text { Hydrogeologic unit } \\
\text { and geologic formation } \\
\text { (with abbreviation) }\end{array}$} & $\begin{array}{c}\text { Number } \\
\text { of wells }\end{array}$ & \multicolumn{3}{c}{$\begin{array}{c}\text { Dissolved lead, } \\
\text { in milligrams per liter }\end{array}$} \\
\cline { 3 - 6 } & & $\begin{array}{c}\text { 10th } \\
\text { percentile }\end{array}$ & Median & $\begin{array}{c}\text { 90th } \\
\text { percentile }\end{array}$ \\
\hline Gettysburg Lowland & 29 & 0.001 & 0.005 & 0.020 \\
Diabase (Trd) & 6 & .002 & .005 & .050 \\
Gettysburg Formation (Trg) & 18 & .003 & .005 & .012 \\
Gettysburg Conglomerate (Trgc) & 2 & .001 & .002 & .003 \\
New Oxford Formation (Trn) & 3 & .001 & .001 & .001 \\
\hline Piedmont Lowland & 2 & .004 & .027 & .050 \\
Conestoga Formation (OCc) & 1 & -- & .004 & -- \\
Kinzers Formation (Ck) & 1 & -- & .050 & -- \\
\hline Piedmont Upland & 3 & .002 & .009 & .010 \\
Harpers Formation (Ch) & 1 & -- & .002 & -- \\
Marburg Schist (Xwm) & 1 & -- & .010 & -- \\
Metabasalt (mb) & 1 & -- & .009 & -- \\
\hline
\end{tabular}


Table 25. Dissolved manganese in ground water from Adams County, Pennsylvania, by hydrogeologic unit and geologic formation

[--, insufficient data available]

\begin{tabular}{lcccc}
\hline \multirow{2}{*}{$\begin{array}{c}\text { Hydrogeologic unit } \\
\text { and geologic formation } \\
\text { (with abbreviation) }\end{array}$} & $\begin{array}{c}\text { Number } \\
\text { of wells }\end{array}$ & \multicolumn{2}{c}{$\begin{array}{c}\text { Dissolved manganese, } \\
\text { in milligrams per liter }\end{array}$} \\
\cline { 3 - 6 } & & $\begin{array}{c}\text { 10th } \\
\text { percentile }\end{array}$ & Median & $\begin{array}{c}\text { 90th } \\
\text { percentile }\end{array}$ \\
\hline Gettysburg Lowland & 58 & 0.0005 & 0.010 & 0.085 \\
Diabase (Trd) & 8 & .0005 & .005 & .020 \\
Gettysburg Formation (Trg) & 31 & .0005 & .006 & .085 \\
Gettysburg Conglomerate (Trgc) & 3 & .0005 & .010 & .050 \\
New Oxford Formation (Trn) & 16 & .0000 & .030 & .090 \\
\hline Piedmont Lowland & 6 & .0000 & .010 & .070 \\
Conestoga Formation (OCc) & 2 & .010 & .020 & .030 \\
Ledger Formation (Cl) & 1 & -- & .0005 & -- \\
Kinzers Formation (Ck) & 2 & .0000 & .005 & .010 \\
Vintage Formation (Cv) & 1 & -- & .070 & -- \\
\hline Piedmont Upland & 4 & .0000 & .060 & .32 \\
Harpers Formation (Ch) & 2 & .0000 & .16 & .32 \\
Marburg Schist (Xwm) & 1 & -- & .10 & - \\
Metabasalt (mb) & 1 & -- & .020 & - \\
\hline
\end{tabular}

Zinc is dissolved from zinc-bearing rocks, and from brass, bronze, or galvanized pipe. Zinc is used as a white pigment in paint and rubber and is present in many industrial wastes and acid mine drainage. Concentrations of zinc greater than $5 \mathrm{mg} / \mathrm{L}$ can be detected by taste; concentrations greater than $30 \mathrm{mg} / \mathrm{L}$ have been known to cause nausea and fainting. Zinc concentrations in the ground water of Adams County are summarized in table 26. Only two wells contained water with zinc concentrations greater than $1 \mathrm{mg} / \mathrm{L}$. One of these wells is located in the Gettysburg Formation; the other is in the Kinzers Formation. The well located in the Kinzers Formation is located near a quarry and also contains water with a lead concentration of $0.05 \mathrm{mg} / \mathrm{L}$.

Table 26. Dissolved zinc in ground water from Adams County, Pennsylvania, by hydrogeologic unit and geologic formation

[--, insufficient data available]

\begin{tabular}{lcccc}
\hline $\begin{array}{c}\text { Hydrogeologic unit } \\
\text { and geologic formation } \\
\text { (with abbreviation) }\end{array}$ & $\begin{array}{c}\text { Number } \\
\text { of wells }\end{array}$ & \multicolumn{3}{c}{$\begin{array}{c}\text { Dissolved zinc, } \\
\text { in milligrams per liter }\end{array}$} \\
\cline { 5 - 6 } & & $\begin{array}{c}\text { 10th } \\
\text { percentile }\end{array}$ & Median & $\begin{array}{c}\text { 90th } \\
\text { percentile }\end{array}$ \\
\hline Gettysburg Lowland & 30 & 0.010 & 0.030 & 0.28 \\
Diabase (Trd) & 6 & .003 & .020 & .090 \\
Gettysburg Formation (Trg) & 18 & .010 & .030 & .78 \\
Gettysburg Conglomerate (Trgc) & 3 & .010 & .020 & .030 \\
New Oxford Formation (Trn) & 3 & .030 & .030 & .040 \\
\hline Piedmont Lowland & 2 & .020 & 1.0 & 2.0 \\
Conestoga Formation (OCc) & 1 & -- & .020 & - \\
Kinzers Formation (Ck) & 1 & -- & 2.0 & -- \\
\hline Piedmont Upland & 3 & .010 & .040 & .070 \\
\hline Harpers Formation (Ch) & 1 & -- & .010 & - \\
Marburg Schist (Xwm) & 1 & -- & .070 & - \\
Metabasalt (mb) & 1 & -- & .040 & -- \\
\hline
\end{tabular}




\section{Organic Compounds}

Ground-water contamination by pesticides and volatile organic compounds (VOC's) is a particular concern because of the widespread use of these compounds in agricultural and industrial applications. Some compounds are persistent in the ground-water environment, thus posing a threat to shallow ground-water supplies and to deep aquifers alike.

\section{Pesticides}

Pesticides are widely used in Adams County. Pesticides are divided into insecticides and herbicides on the basis of their use. Insecticides are used to control crop-damaging insects, household, and garden insects. Herbicides are used to control weeds that compete with crops in agricultural areas and home gardens. Herbicides also are used to control broad-leaf weeds on lawns and turf and to defoliate utility, railroad, and highway rights-ofways. Pesticide data for 32 wells are summarized in Appendix A and in table 27; the locations of these wells are shown in figure 8 . Of the seven wells containing water with detectable amounts of pesticides, five are located on the Gettysburg National Battlefield. The small sample population prevents any statistical comparisons between hydrogeologic units, geologic formations, or areal distribution.

Organophosphorus insecticides were created as substitutes for banned organochlorine insecticides because they are less persistent in the environment and more selective in their targets. Malathion was detected in the water from one well drilled in the Gettysburg Formation; diazinon was detected in the water from one well drilled in the Gettysburg Formation and in another well in diabase (table 27). Malathion and diazinon commonly are used in Pennsylvania (Hartwig and others, 1980, p. 8-9). Malathion and diazinon are recommended for use in the mushroom industry (Tetrault and Wuest, 1979) and are widely used in agriculture, in homes, and in gardens for insect control.

Triazine herbicides are mainly used for preemergence applications on grass and broadleaf weeds. Atrazine, which is the most widely used herbicide in Pennsylvania (Hartwig and others, 1980 , p. 8-9), was detected in the water from three wells - two in the Gettysburg Formation and one in the diabase. Simazine also was present in the water from one of the three wells containing
Table 27. Pesticides detected in ground water, Adams County, Pennsylvania

[--, not applicable]

\begin{tabular}{|c|c|c|c|}
\hline Compound & $\begin{array}{l}\text { Number of } \\
\text { wells } \\
\text { in which } \\
\text { compound } \\
\text { was } \\
\text { detected }\end{array}$ & $\begin{array}{l}\text { Maximum } \\
\text { concentra- } \\
\text { tion, } \\
\text { in micro- } \\
\text { grams } \\
\text { per liter }\end{array}$ & $\begin{array}{l}\text { U.S. Environmental } \\
\text { Protection Agency } \\
\text { Maximum } \\
\text { Contaminant Level, } \\
\text { in micrograms } \\
\text { per liter }\end{array}$ \\
\hline \multicolumn{4}{|c|}{ Organophosphorus insecticides } \\
\hline Malathion, total & 1 & 0.010 & - \\
\hline Diazinon, total & 2 & .010 & - \\
\hline \multicolumn{4}{|c|}{$\underline{\text { Triazine herbicides }}$} \\
\hline Atrazine, total & 1 & .100 & 3.0 \\
\hline $\begin{array}{l}\text { Atrazine, } \\
\text { dissolved }\end{array}$ & 2 & .012 & 3.0 \\
\hline $\begin{array}{l}\text { Prometone, } \\
\text { total }\end{array}$ & 1 & .200 & - \\
\hline $\begin{array}{l}\text { Simazine, } \\
\text { dissolved }\end{array}$ & 1 & .005 & 4.0 \\
\hline \multicolumn{4}{|c|}{ Organic acid herbicides } \\
\hline Picloram, total & 1 & .010 & .5 \\
\hline $2,4-\mathrm{D}$, total & 1 & .010 & .07 \\
\hline Silvex, total & 1 & .010 & -- \\
\hline Dicamba, total & 1 & .030 & -- \\
\hline
\end{tabular}

detectable levels of atrazine. Concentrations of atrazine and simazine in the water from the three wells were well below the USEPA MCL (table 27). Prometone was detected in the water of one well drilled in the Gettysburg Formation.

Organic acid herbicides were detected in two wells (table 27). Dicamba, silvex, and 2,4-D were all detected in the water from one well drilled into diabase. This well also contained water with detectable amounts of diazinon. Picloram was detected in the water from one well drilled in the Gettysburg Formation. Dicamba and 2,4-D are widely used herbicides (Hartwig and others, 1980, p. 8-9) in controlling broadleaf weeds in corn, grain, and turf. Picloram and 2,4-D are commonly used along rights-of-way. Silvex was used for the control of woody plants and weeds but was discontinued in 1984.

Studies of pesticides in ground water in the Mid-Atlantic region (Ator and Ferrari, 1997), specifically the Potomac River Basin (Ator and others, 1998) and the Lower Susquehanna River Basin (Lindsey and others, 1998), relate the occurrence of selected pesticides in ground water to land use and rock type. The highest concentrations of pesticides were in samples collected in the agricultural areas of southcentral Pennsylvania 

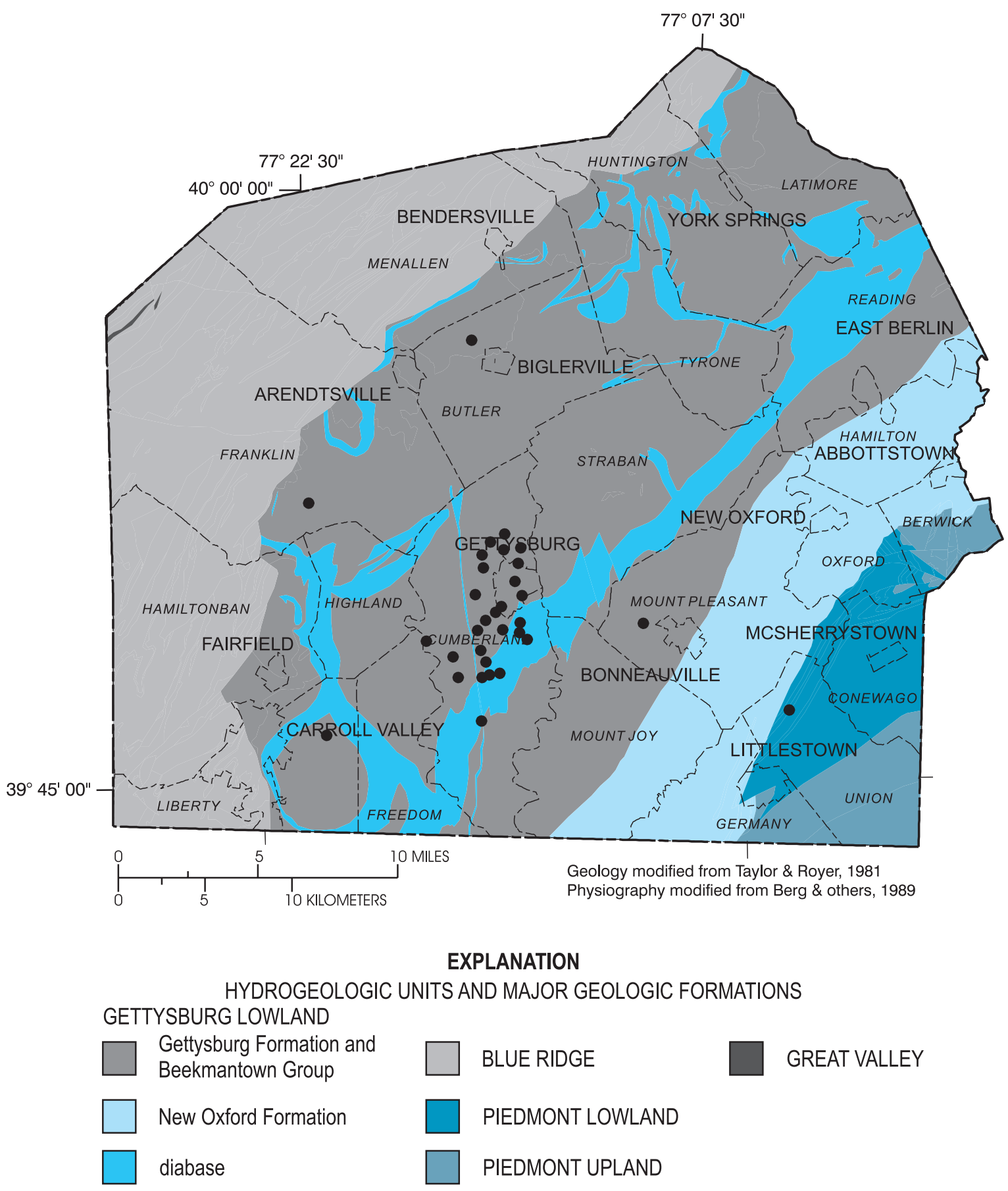

- LOCATION OF WELLS THAT WERE SAMPLED FOR PESTICIDES

Figure 8. Location of wells in Adams County, Pennsylvania, where ground water was sampled for analysis of pesticides. 
and Maryland, but these concentrations rarely exceeded USEPA MCL's. The lowest detection frequencies of pesticides were in forested areas; the highest detection frequencies were in areas underlain by carbonate rock. Ground water in crystalline rocks also contained higher concentrations of pesticides than areas underlain by siliciclastic rocks. Thus, in Adams County, wells located within the carbonate rocks of the Piedmont Lowland hydrogeologic unit and agricultural areas in the sandstones and shales of the Gettysburg Lowland unit are probably most susceptible to pesticide contamination.

\section{Volatile Organic Compounds}

VOC's have been used extensively for industrial, commercial, or domestic applications since the 1920's (Petura, 1980). Their presence in ground water presents a serious problem for domestic and industrial well owners and public suppliers who utilize ground water to meet their customer needs. VOC's typically enter the groundwater system from point sources such as leaking storage tanks, spills, disposal sites, or septic systems. Once in the subsurface, VOC's are difficult and expensive to remove.

A relatively large number of wells (more than 325 wells) have been sampled for the presence of VOC's in Adams County. Most wells sampled for VOC's, however, were part of ground-water investigations to determine the extent of contamination at or in the vicinity of the Keystone Superfund Site, the Shrivers Corner Superfund Site, the Hunterstown Superfund Site, the Gettysburg Elevator Superfund Site, or the Pennsylvania-led J.C. Cleaners site (fig. 9). Concentrations of VOC's that exceeded the USEPA MCL's for selected constituents were detected from a small number of onsite and offsite monitor wells and a few domestic wells. In many cases, the contaminated ground waters were discovered after homeowners reported a disagreeable taste or smell from their water well. Aside from the location of the five hazardous waste sites, figure 9 also shows the location of nondomestic wells sampled for VOC's. Most of these wells were sampled as part of Pennsylvania's Department of Environmental Protection well-permitting protocols or a USGS investigation in the vicinity of the Gettysburg National Military Park and the Eisenhower National Historic Site (Becher, 1989). Although a few of these 34 wells had trace amounts of VOC's, none contained water that exceeded the MCL's for the analyzed compounds (table 28). Additional VOC data from the 34 nondomestic wells are presented in Appendix B.

Table 28. Volatile organic compounds detected in ground water, Adams County, Pennsylvania

[--, not applicable]

\begin{tabular}{lccc}
\hline \multicolumn{1}{c}{ Compound } & $\begin{array}{c}\text { Number of } \\
\text { wells } \\
\text { in which } \\
\text { compound } \\
\text { was } \\
\text { detected }\end{array}$ & $\begin{array}{c}\text { Maximum } \\
\text { concentra- } \\
\text { tion, } \\
\text { in micro- } \\
\text { grams } \\
\text { per liter }\end{array}$ & $\begin{array}{c}\text { U.S. Environmental } \\
\text { Protection Agency } \\
\text { Maximum }\end{array}$ \\
$\begin{array}{lccc}\text { Contaminant Level, } \\
\text { in micrograms } \\
\text { per liter }\end{array}$ \\
\hline Benzene & 1 & 0.2 & 5.0 \\
Chlorobenzene & 1 & .4 & -- \\
Chloroethane & 1 & 1.7 & -- \\
Chloroform & 4 & .3 & -- \\
1,1-Dichloroethane & 1 & .3 & -- \\
1,2-Dichloroethane & 1 & 1.6 & 5.0 \\
Tetrachloroethylene & 4 & .9 & 5.0 \\
Toluene & 1 & 1.0 & 1,000 \\
1,1,1-Trichloroethane & 1 & .5 & 200 \\
Trichloroethylene & 3 & .7 & 5.0 \\
\hline
\end{tabular}

\section{Radionuclides}

Radionuclides, such as radon-222, uranium, thorium, and tritium, are naturally present in the ground water of Adams County and may present a health problem if activities are elevated. Radioactivity is the result of unstable elements, such as uranium-238 and thorium-232, decaying or releasing energy and energetic particles as they break down to form a stable lead isotope. The uranium-238 decay series produces the greatest amount of radioactivity in ground water (Hem, 1985, p. 147). Its daughter products include radium-226 and radon-222. Radon-222 is a colorless, odorless, inert, alpha-particle-emitting gas that is soluble in water. Radon forms below the land surface and enters the air in homes through the basement or, if dissolved in the ground water, through everyday uses of the water such as cooking or showering. Radon in ground water may be of greatest concern for those who use private wells for their water supply because radon in public water supplies may have time to decay to low concentrations before the user receives the water (Lindsey and Ator, 1996).

Radionuclides, uranium, and tritium were detected in the water of all five of the wells sampled. Radon-222 was detected in all 10 of the 


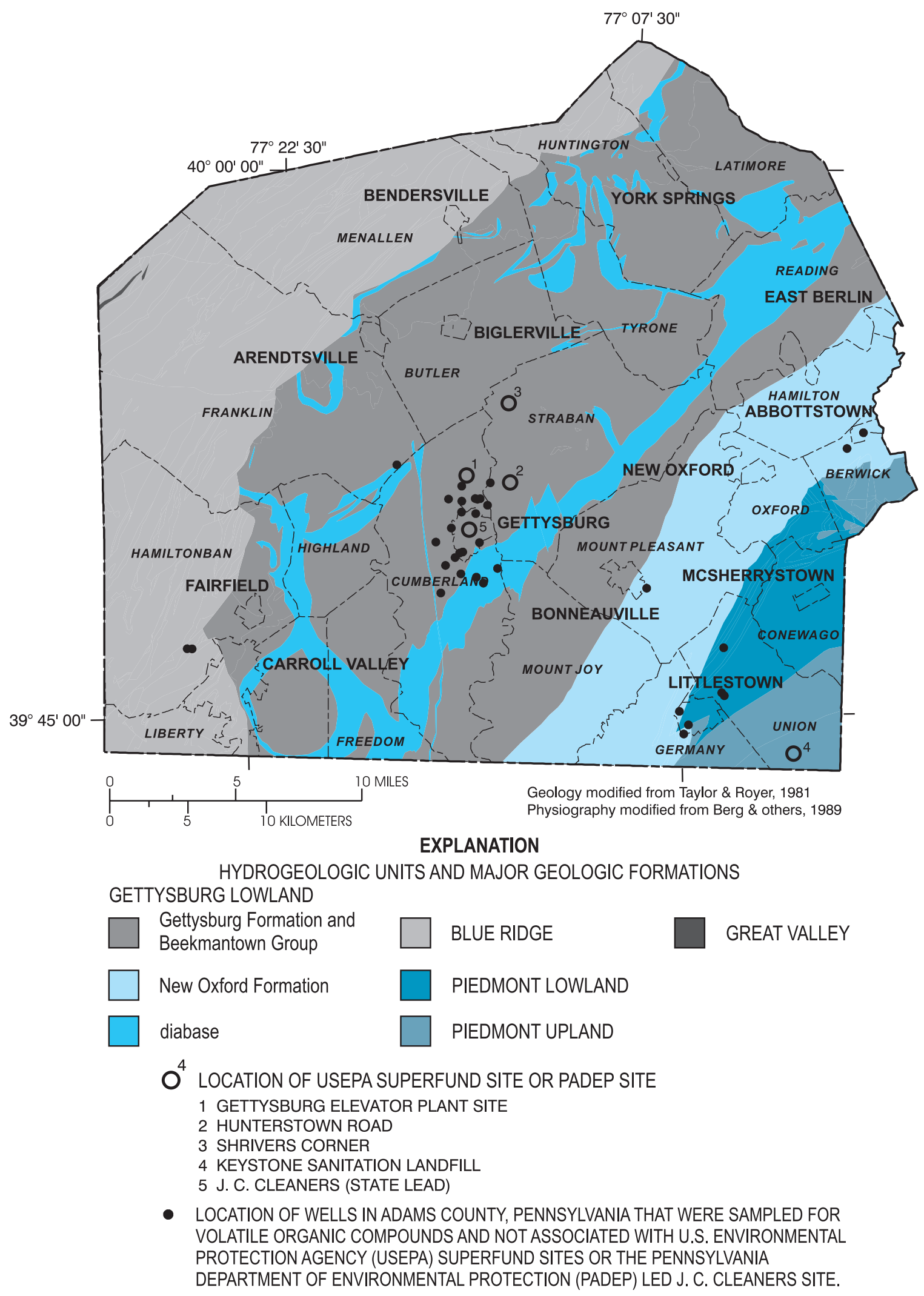

Figure 9. Location of hazardous waste sites and wells in Adams County, Pennsylvania, that were sampled for analysis of volatile organic coumpounds not associated with hazardous waste site assessment or other such activities. 
wells sampled and analyzed for this constituent. Concentrations of total radon-222 ranged from 230 to $9,870 \mathrm{pCi} / \mathrm{L}$, uranium from 0.14 to $5.8 \mathrm{pCi} / \mathrm{L}$, and tritium from 1 to $48 \mathrm{pCi} / \mathrm{L}$. Wells that contained water with the highest uranium concentrations also had the highest radon-222 concentrations. At present, there is no MCL for radon although the National Academy of Sciences (written commun., 1998) suggests an alternative MCL of $4,000 \mathrm{pCi} / \mathrm{L}$. For uranium, the USEPA MCL is $0.02 \mathrm{mg} / \mathrm{L}$. The USEPA MCLG for radon222 and uranium, however, is 0.0 .

In a recent study of radon in ground water of the Lower Susquehanna and Potomac River Basins, Lindsey and Ator (1996) report that 80 percent of the samples contained radon at concentrations greater than $300 \mathrm{pCi} / \mathrm{L}$; many samples had concentrations greater than $1,000 \mathrm{pCi} / \mathrm{L}$. The highest median radon concentrations (ranging from 1,200 to 3,100 pCi/L) within these basins were in areas underlain by igneous and metamorphic rocks or sandstone and shale rocks. In Adams County, these areas are the crystalline rocks in the Piedmont Upland hydrogeologic unit and the sandstone and shale rocks in the Gettysburg Lowland unit. Areas underlain by limestone and dolomite, such as the Piedmont Lowland, had lower median concentrations of radon in the ground water, generally between 300 and 1,000 pCi/L (Lindsey and Ator, 1996).

\section{HYDROGEOLOGIC FRAMEWORK AT SELECTED WELL SITES}

The hydrogeologic framework in the vicinity of four public-supply well fields within three different hydrogeologic units in Adams County was investigated to provide information that would help guide delineations of wellheadprotection areas. Two well fields are in the Gettysburg Lowland near the communities of Gettysburg and Abbottstown. Another well field is in the Blue Ridge several miles west of Fairfield. The fourth well field is in the Piedmont Lowland near the Borough of Littlestown (fig. 2).

Conceptual diagrams of the hydrogeologic framework within each hydrogeologic unit are presented and described in detail in the following sections. In general, the hydrogeologic framework consists of an upper highly weathered zone underlain by a zone of more competent bedrock (fig. 10).
The highly weathered zone (if saturated) is bounded at the top by the water table and below by bedrock in which secondary porosity and (sometimes) permeability are considerably lower. The highly weathered zone is comprised of saturated regolith (a fragmental and unconsolidated material that includes alluvium, colluvium, soil, and saprolite) and weathered bedrock. The regolith is important because its permeability and high porosity allow infiltration and storage of large quantities of water in intergranular pores; however, this capacity to store and transmit water can vary considerably depending on the parent material (Gerhart and Lazorchick, 1988, table 12; Sloto and Davis, 1983, p. 32; Wood, 1980, p. 16). The porosity of the regolith typically far exceeds that of the underlying fractured bedrock, but the saturated regolith by itself commonly is not thick or permeable enough to provide sustained yields of water to wells. Instead, the regolith acts as a reservoir, slowly releasing water to the underlying fractured bedrock in which most wells are completed. Beneath the regolith is a highly weathered zone. Here, weathering has extensively altered the hydraulic properties of the rock. Although weathering generally increases the capacity of rocks to transmit and store water, in some highly weathered arkosic or subarkosic sandstones and conglomerates, clays produced by the alteration of feldspars can reduce the permeability of the rock or prevent any significant increase in permeability (Johnston, 1966, p. 16-19). Ground water in the upper highly weathered zone is generally unconfined or semiconfined depending on the amount of clay present. Groundwater flow in general is influenced more strongly by the topography of the land surface and bedrock surface than by geologic structure.

The lower bedrock zone consists of slightly weathered to highly competent or fractured bedrock. Secondary openings such as joints, faults, fractures, and bedding planes are the main pathways for ground-water flow through each of the four public-supply well fields studied. As depth increases, horizontal openings along bedding planes tend to close; faults and high-angle fractures then become the dominant pathways. With increasing depth, the interconnection between secondary openings is reduced and most ground-water circulation ceases. Ground water in 


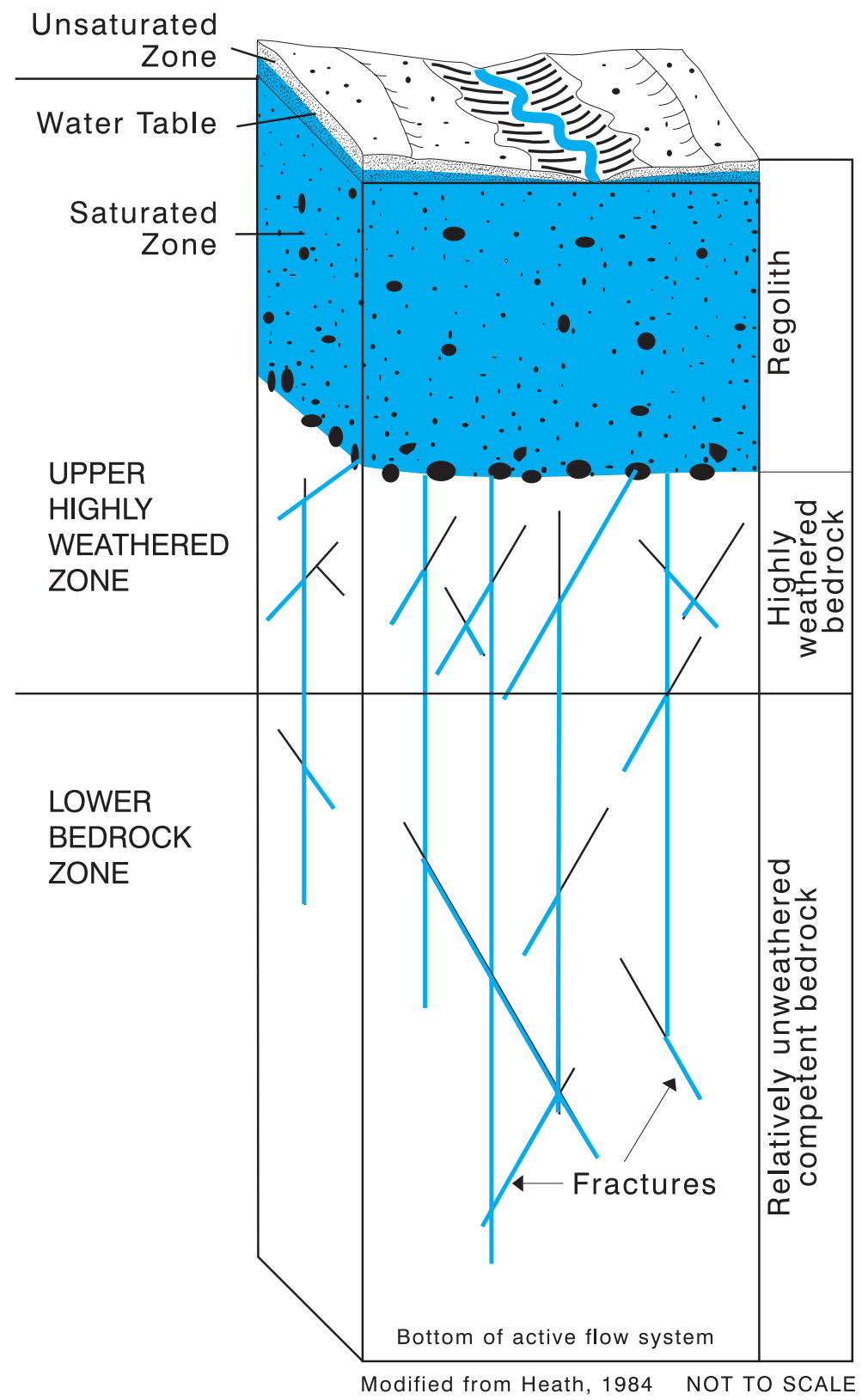

Figure 10. Hydrogeologic framework of the upper highly weathered zone and the lower bedrock zone. 
the lower bedrock zone is generally confined because of the presence of low permeability layers and the presence of relatively few fractures. The time since ground water recharged the lower bedrock zone is variable and can be measured in years. For example, Nelms and Brockman (1997) used chlorofluorocarbons and tritium to model recharge ages in Prince William County, Va. They also noted high-capacity wells tend to have younger recharge ages than those estimated for low-yield domestic wells. Ground-water flow pathways can be complex because they are controlled by the secondary fractures in the bedrock (Gerhart and Lazorchick, 1988, fig. 4).

\section{Gettysburg Lowland - Gettysburg Well AD-343}

Gettysburg well AD-343 (locally known as GMA Well 5) is located just east of Gettysburg, Pa., in Straban Township (fig. 11). The area around the well is characterized by residential, commercial, and agricultural land uses. The Gettysburg Formation, which underlies the area, is moderately resistant to weathering, forming undulating hills of low relief to small hills and ridges that are higher than the surrounding countryside. About $0.5 \mathrm{mi}$ to the south and east of the well field is a large diabase sill that rises 50 to $200 \mathrm{ft}$ above the surrounding landscape.

Well AD-343 was reportedly drilled to a depth of $420 \mathrm{ft}$ and cased to $57.5 \mathrm{ft}$ below land surface (bls). Water-bearing zones were penetrated at depths of 100, 200, 260, and $320 \mathrm{ft}$ bls (table 29). The well is pumped continuously ( 24 hours a day) at approximately $184 \mathrm{gal} / \mathrm{min}$.

\section{Conceptual Ground-Water Flow System Near Well AD-343}

A conceptual diagram of ground-water flow in the vicinity of well AD-343 was developed from published information describing general hydrogeologic conditions of fractured rock and unpublished information from the Gettysburg area including driller's logs (table 29), borehole geophysics, water levels, and aquifer tests. Because very little information was available regarding the hydrogeologic properties in the immediate vicinity of well AD-343, much of the detailed discussion in this section was based on results from extensive site characterization work at the Gettysburg Elevator Plant Superfund Site (fig. 11) by Rizzo Associates, Inc. (1991), and Cummings/Riter Consultants, Inc. (1997), and from Gerhart and
Lazorchick (1988), who created a ground-water flow model of the Lower Susquehanna River Basin in Pennsylvania and Maryland.

A conceptual diagram of the hydrogeologic framework in the vicinity of well AD-343 is shown in figure 12 and described in the following sections. In general, the hydrogeologic framework shows a heterogeneous, multiaquifer system of dipping geologic units within the Gettysburg Formation that have differing hydrologic properties. An upper, highly weathered zone overlies a lower bedrock zone and truncates the dipping geologic units parallel to land surface.

\section{Upper Highly Weathered Zone}

Gettysburg Formation.-The upper highly weathered zone of the Gettysburg Formation consists of about 20 to $50 \mathrm{ft}$ of relatively porous but poorly permeable regolith and shallow, weathered bedrock (where both are saturated). Soil drainage is poor because of the abundance of lowpermeability clay in the soil. Ground water is generally unconfined or semiconfined. Where lowpermeability clays are absent, recharge can be rapid, as evidenced by water-level hydrographs at the Gettysburg Elevator Superfund Site. Groundwater flow is probably influenced more strongly by the topography of the land surface and bedrock surface than by geologic structure, but bedding planes can produce some anisotropic effects. The upper, highly weathered zone is an important ground-water source to the less weathered lower bedrock zone. The hydraulic conductivity of the upper highly weathered zone in the immediate area of well AD-343 is not known, but hydraulic conductivities estimated by Rizzo Associates, Inc. (1991), at the Gettysburg Elevator Superfund Site range from 0.28 to $1.4 \mathrm{ft} / \mathrm{d}$.

Diabase Sill.-The upper highly weathered zone of the diabase sill consists of about 5 to $30 \mathrm{ft}$ of clay-rich soil, sand, and weathered bedrock (where both are saturated). Ground water is generally unconfined. Ground-water flow is strongly influenced by local topography and the amount of clay filling the openings of the weathered rock. Because of the clay-rich overburden and the thin, clay-filled weathered bedrock, little ground-water storage is available to supply the lower bedrock zone. Because of the abundance of clay, this upper highly weathered 


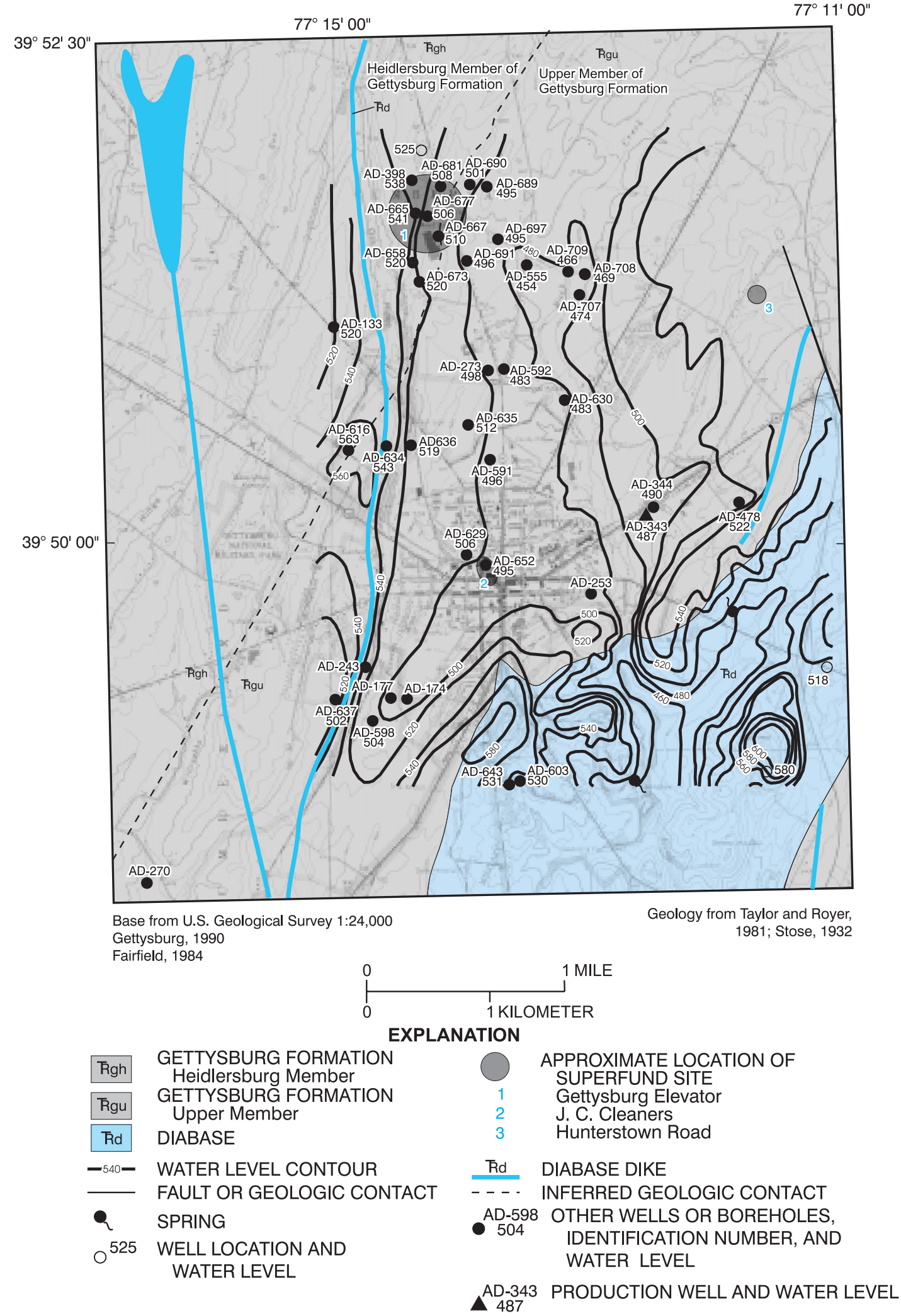

Figure 11. Location of well AD-343, selected other wells, Gettysburg Elevator and Hunterstown Road Superfund Sites, Pennsylvania led J.C. Cleaners Site, general geology, and water-level contours in the vicinity of Gettysburg, Pennsylvania. 
Table 29. Record of selected wells in the vicinity of Gettysburg, Pennsylvania

[Location of wells are shown in figure 11. Depth in feet below land surface; gal $/ \mathrm{min}$, gallons per minute; $(\mathrm{gal} / \mathrm{min}) / \mathrm{ft}$, gallons per minute per foot of drawdown; --, not available; P, public; U, unused public; $\mathrm{A}$, abandoned public; $\mathrm{C}$, commercial; D, domestic; M, monitor; GBRG, Gettysburg Formation]

\begin{tabular}{|c|c|c|c|c|c|c|c|c|c|c|}
\hline $\begin{array}{c}\text { Well } \\
\text { number }\end{array}$ & $\begin{array}{l}\text { Well } \\
\text { depth }\end{array}$ & $\begin{array}{l}\text { Casing } \\
\text { length }\end{array}$ & $\begin{array}{l}\text { Reported } \\
\text { yield } \\
\text { (gal/min) }\end{array}$ & $\begin{array}{c}\text { Specific } \\
\text { capacity } \\
{[(\text { gal } / \mathrm{min}) / \mathrm{ft}]}\end{array}$ & $\begin{array}{l}\text { Reported } \\
\text { depth to } \\
\text { water }\end{array}$ & $\begin{array}{c}\text { Date } \\
\text { water level } \\
\text { measured }\end{array}$ & $\begin{array}{c}\text { Reported } \\
\text { depth to } \\
\text { water-bearing } \\
\text { zone }\end{array}$ & $\begin{array}{l}\text { Water } \\
\text { use }\end{array}$ & $\begin{array}{l}\text { Depth to } \\
\text { bedrock }\end{array}$ & Aquifer \\
\hline AD-174 & 500 & 47 & 183 & 1.2 & 50 & $10-11-1966$ & $180,200,220,397$ & $P$ & 4 & GBRG \\
\hline AD-177 & 499 & 32 & 180 & 1.2 & 64.72 & 09-03-1968 & -- & $U$ & -- & GBRG \\
\hline AD-253 & 605 & 43 & 40 & .12 & 15 & 04-24-1969 & $\begin{array}{l}105,195,315 \\
350,385,490\end{array}$ & A & -- & GBRG \\
\hline AD-270 & 655 & 65 & 150 & .55 & 19.7 & 06-14-1976 & $\begin{array}{l}72,222,262,330 \\
513,562,587,615\end{array}$ & $P$ & -- & GBRG \\
\hline AD-343 & 420 & 57.5 & 300 & 1.1 & 12.90 & 08-10-1976 & $100,200,260,320$ & $P$ & 20 & GBRG \\
\hline AD-344 & 220 & 80 & 48 & .27 & 10 & 01-30-1973 & $100,150,190$ & C & 10 & GBRG \\
\hline AD-478 & 350 & 20 & 2 & .01 & 58 & 09-01-1979 & 112 & $D$ & 8 & GBRG \\
\hline AD-591 & 900 & 84 & 300 & .34 & 9.43 & $10-10-1986$ & $\begin{array}{c}74,157,221,237, \\
368,383,399,421, \\
494,513,621,632, \\
694,732,782,836, \\
879,900\end{array}$ & $P$ & 4 & GBRG \\
\hline AD-598 & 425 & 36 & -- & -- & 46.23 & $10-10-1986$ & -- & $U$ & -- & GBRG \\
\hline AD-629 & 900 & 43 & 325 & -- & 14 & 04-03-1986 & $\begin{array}{l}117,159,208,428 \\
500,635,719,725\end{array}$ & $P$ & 5 & GBRG \\
\hline AD-652 & 275 & 20 & 9 & 8.2 & 30.08 & $12-17-1986$ & $80,120,140,180$ & C & -- & GBRG \\
\hline AD-658 & 250 & 185 & .1 & -- & 31.68 & 08-17-1997 & -- & M & 4 & GBRG \\
\hline AD-667 & 182 & 127 & 9 & -- & 37.42 & 08-17-1997 & $49,114,141$ & M & 3 & GBRG \\
\hline AD-677 & 180 & 160 & 40 & -- & 30.63 & 08-17-1997 & $121,135,177$ & M & 4 & GBRG \\
\hline AD-707 & 645 & 21 & 135 & -- & 25.5 & 09-12-1995 & $\begin{array}{c}119,171,238,267 \\
293,373,482,529 \\
606,635\end{array}$ & $\mathrm{U}$ & 4 & GBRG \\
\hline AD-708 & 368 & 20 & 28 & .09 & 21 & 09-08-1995 & $\begin{array}{c}144,176,204,230 \\
283,368\end{array}$ & $U$ & 2 & GBRG \\
\hline AD-709 & 715 & 20 & 210 & .79 & 13.7 & 09-26-1995 & $\begin{array}{c}56,100,288,323 \\
389,429,481,507 \\
564,590,615,646 \\
682\end{array}$ & $U$ & 4 & GBRG \\
\hline
\end{tabular}




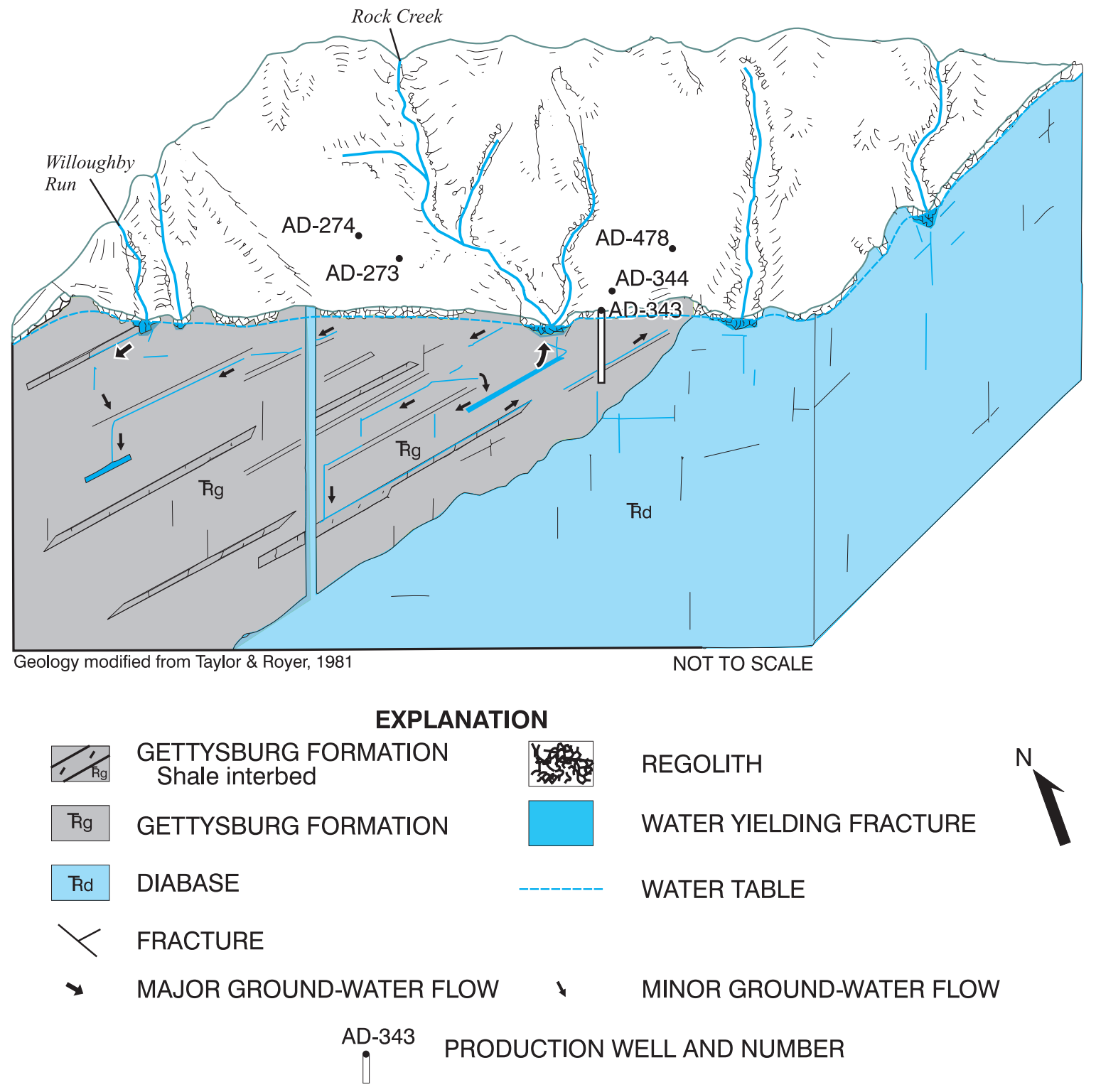

Figure 12. General geology and ground-water flow near Gettysburg well AD-343. 
zone represents a confining unit to the lower, less weathered diabase bedrock. Flow directions are probably dominantly horizontal as a result of the abundance of clay and the clay's low permeability. Estimates of hydraulic conductivity or transmissivity are not available.

\section{Lower Bedrock Zone}

Gettysburg Formation.-The Gettysburg Formation within the lower bedrock zone consists of competent, fractured shale and siltstone with minor amounts of sandstone. The water-producing or water-receiving zones consist almost entirely of secondary openings such as bedding planes, fractures, faults, and joints, which form a sequence of alternating tabular, siltstone aquifers that dip 1530 degrees to the northwest (Taylor and Royer, 1981, plate 1). Joints parallel to bedding probably serve as the primary flow paths in many of the tabular aquifers whereas high-angle joints provide the interconnection between aquifers (LewisBrown and Jacobsen, 1995). These tabular aquifers are overlapping, lens-shaped, and discontinuous and commonly are separated by tens to hundreds of feet of shale with negligible effective porosity or permeability (Wood, 1980). The borehole caliper log for well AD-343 (fig. $13^{1}$ ) and drillers' logs for other wells (table 29) indicate these tabular aquifers may extend down dip for hundreds to perhaps a thousand feet or more below land surface. However, the lower bedrock zone thins rapidly in the up dip direction towards the diabase sill (fig. 12).

Ground water is generally unconfined at shallow depths but becomes confined as it moves in a down dip direction. The depth and direction of active ground-water flow can sometimes be determined from geophysical logs and flowmetering. The absence of any appreciable change in slope on the fluid-temperature and fluid-resistivity logs of well AD-343 from a depth of 200 to $400 \mathrm{ft}$ bls may indicate vertical movement of water within the borehole (fig. 13). This vertical flow is the result of significant head differences between water-bearing fractures. In order to better

\footnotetext{
${ }^{1}$ The borehole geophysical logs shown in figure 13 were collected under nonpumping conditions by an analog type recorder on November 3, 1976. The blocky appearance of the $\operatorname{logs}$ is the result of converting the analog data to a digital format by selecting individual $\log$ values every $1.0 \mathrm{ft}$. The interpretations of the logs, however, are based on the analog data.
}

determine the vertical direction and volume of flow in the borehole, a small quantity of concentrated saline water (brine) was injected in well AD-343 at depths of 80,160, and $220 \mathrm{ft}$ bls but did not show vertical flow (this method of determining borehole flow has a minimum flow detection capability of 1-2 gal/min). Brine injected at a depth of $320 \mathrm{ft}$, however, indicated water was moving upward at about $2.5 \mathrm{gal} / \mathrm{min}$. The major fractures at $371-386 \mathrm{ft}$ bls are believed to be the source of the water entering well AD-343 (fig. 13). Brine also was injected under nonpumping conditions in wells AD-591, AD-598, AD-629, and $\mathrm{AD}-652$. The results of these efforts are summarized in table 30 and indicate ground-water movement can occur to a depth of at least $800 \mathrm{ft}$ bls.

The aquifer properties of the lower bedrock zone of the Gettysburg Formation at well AD-343 are not known, but the median hydraulic conductivity and transmissivity based on 193 single-well aquifer tests in the lower zone of the Gettysburg Formation are $0.55 \mathrm{ft} / \mathrm{d}$ and $57 \mathrm{ft}^{2} / \mathrm{d}$ (Dennis J. Low and others, U.S. Geological Survey, written commun., 1998), respectively (table 31). Hydraulic conductivity and transmissivity were calculated from 1 hour or longer, single-well aquifer tests or specific-capacity tests by use of a modified Theis formula (Theis and others, 1963). Estimates of transmissivity at the Gettysburg Elevator Plant Superfund Site and wells AD-270 and AD-591 owned by the Gettysburg Municipal Authority are presented in table 32. Gerhart and Lazorchick (1988) used hydraulic conductivities of 2.67 and $0.40 \mathrm{ft} / \mathrm{d}$ for the lower bedrock zone near Gettysburg, Pa.

Rizzo Associates, Inc. (1991), utilized a doublepacker system at the Gettysburg Elevator Plant Superfund Site to isolate individual horizons in seven monitor wells ranging in depth from 60 to $245 \mathrm{ft}$. In general, they reported the lower bedrock zone was characterized by much lower hydraulic conductivities $(0.00028 \mathrm{ft} / \mathrm{d})$ than the upper highly weathered zone, except where the rock was weathered, broken, or contained water-bearing zones. At these permeable horizons, the hydraulic conductivity of the rock was as great as $2.8 \mathrm{ft} / \mathrm{d}$.

The lower bedrock zone is probably anisotropic with respect to hydraulic conductivity, although the degree of anisotropy at the well site is unknown. Multiple-well aquifer tests (Cummings/Riter, Consultants Inc., 1997) at the Gettysburg Elevator Plant Superfund Site (fig. 11) 

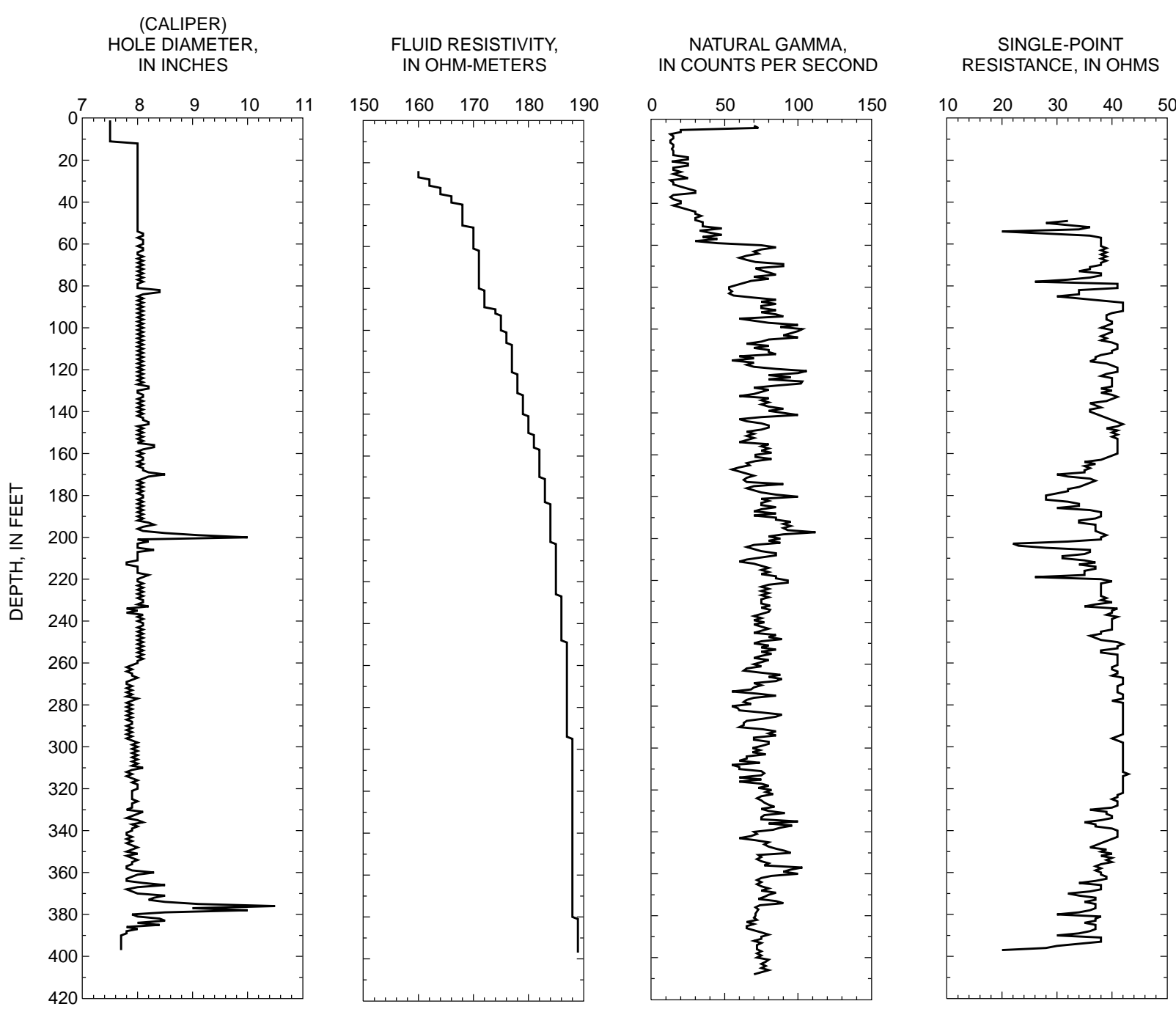

FLUID TEMPERATURE,
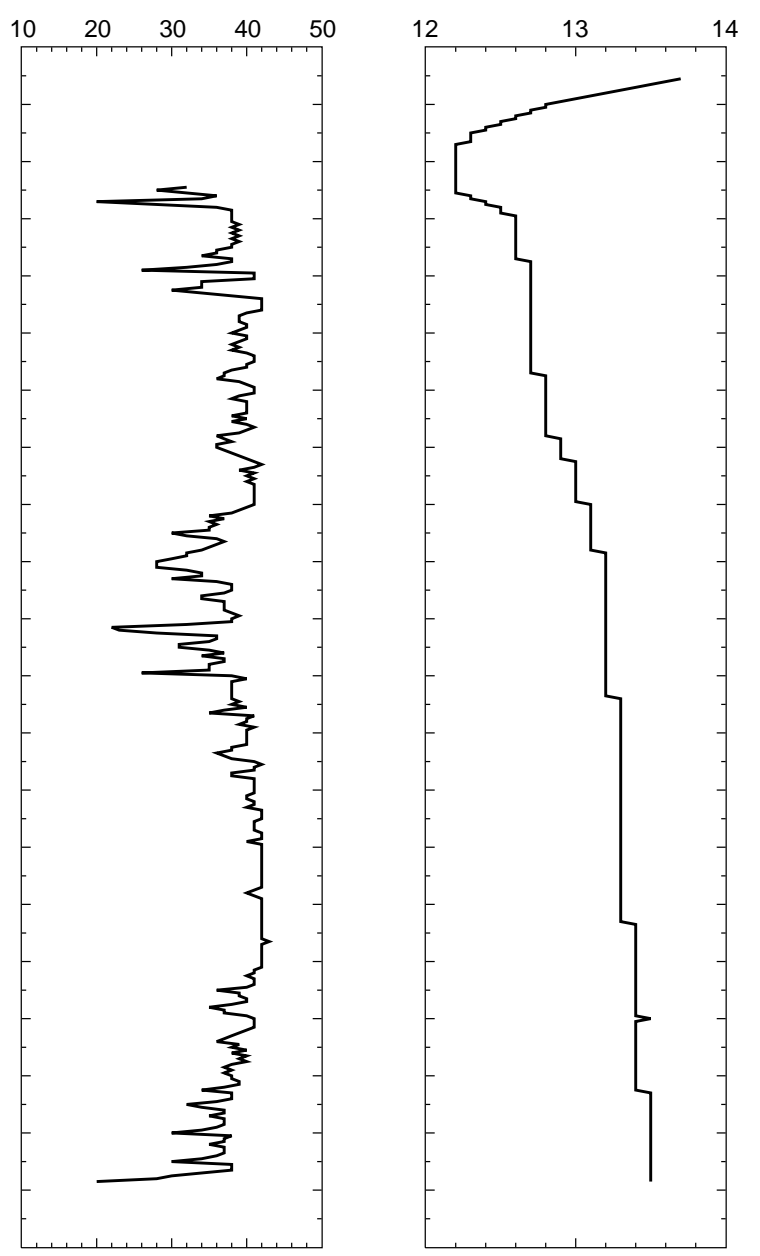

Figure 13. Borehole geophysical logs for borehole AD-343, November 3, 1976 (analog data converted to digital data for this figure). 
Table 30. Summary of brine-tracing measurements for wells $A D-591$, $A D-598, A D-629$, and $A D-652$ in the vicinity of Gettysburg, Pennsylvania [--, not applicable]

\begin{tabular}{cccc}
\hline $\begin{array}{c}\text { Well } \\
\text { number }\end{array}$ & $\begin{array}{c}\text { Depth } \\
\text { (feet below } \\
\text { land surface) }\end{array}$ & $\begin{array}{c}\text { Flow rate under } \\
\text { ambient conditions } \\
\text { (gallons per minute) }\end{array}$ & $\begin{array}{c}\text { Flow direction } \\
\text { under ambient } \\
\text { conditions }\end{array}$ \\
\hline AD-591 & 360 & no flow & -- \\
AD-598 & 600 & no flow & -- \\
& 800 & -- & Down \\
AD-629 & 200 & -- & Down (?) \\
& 302 & 6 & Down \\
& 300 & -- & Down \\
AD-652 & 600 & -- & Down \\
& 70 & -- & Down \\
& 152 & no flow & -- \\
& 222 & no flow & -- \\
\hline
\end{tabular}

Table 31. Hydraulic conductivity and transmissivity from single-well aquifer tests or specific-capacity tests in the Gettysburg Formation throughout Pennsylvania

[Note: Hydraulic conductivity and transmissivity were calculated from specific-capacity tests by the method of Theis and others, 1963 , using a specific yield of 0.007 ; $\mathrm{ft} / \mathrm{d}$, feet per day; $\mathrm{ft}^{2} / \mathrm{d}$, feet squared per day]

\begin{tabular}{|c|c|c|c|c|c|c|c|c|}
\hline \multirow{2}{*}{$\begin{array}{l}\text { Hydraulic } \\
\text { property }\end{array}$} & \multirow{2}{*}{$\begin{array}{l}\text { Number } \\
\text { of wells }\end{array}$} & \multicolumn{5}{|c|}{$\begin{array}{l}\text { Percentage of wells in which } \\
\text { value was equaled or exceeded }\end{array}$} & \multirow{2}{*}{ Minimum } & \multirow{2}{*}{ Maximum } \\
\hline & & 90 & 75 & $\begin{array}{c}50 \\
\text { (median) }\end{array}$ & 25 & 10 & & \\
\hline Hydraulic conductivity (ft/d) & 193 & 0.05 & 0.16 & 0.55 & 1.5 & 4.6 & 0.00 & 120 \\
\hline Transmissivity $\left(\mathrm{ft}^{2} / \mathrm{d}\right)$ & 193 & 6.8 & 22 & 57 & 230 & 550 & .64 & 4,400 \\
\hline
\end{tabular}

Table 32. Summary of hydraulic properties from single- and multiple-well aquifer tests for the Gettysburg Formation in the vicinity of Gettysburg, Pennsylvania

[Data for wells AD-270 and AD-591 from Gettysburg Municipal Authority; data for wells AD-658, AD-667, and AD-677 from Cummings/Riter, 1997; transmissivity and storativity determined by Larry Taylor, Hydro Science, Inc., written commun., 1998; --, not applicable]

\begin{tabular}{ccc}
\hline $\begin{array}{c}\text { Well } \\
\text { number }\end{array}$ & $\begin{array}{c}\text { Transmissivity } \\
\text { (feet squared } \\
\text { per day) }\end{array}$ & Storativity \\
\hline AD-270 & 750 & -- \\
AD-591 & 6,800 & -- \\
AD-658 & 1,900 & 0.00009 \\
AD-667 & 750 & .000031 \\
AD-677 & 690 & .000073 \\
\hline
\end{tabular}


indicate that (1) when grouped together, the tabular, lens shaped aquifers of the lower bedrock zone are strongly anisotropic with the highest hydraulic conductivity parallel to strike, (2) cones of depression extend from the pumping well in a strike direction for hundreds to thousands of feet, and (3) ground-water flow paths and capture zones will be affected by the anisotropy imparted by the dipping tabular aquifers. An anisotropy ratio along strike versus across strike of about 25:1 for the lower layer is indicated from the difference between the direction of the hydraulic gradient and movement of contaminants from the Gettysburg Elevator Plant Superfund site. Becher (1989) also observed anisotropy with the direction of greatest hydraulic conductivity parallel to strike and noted that many Gettysburg Municipal Authority wells had overlapping elliptical cones of depression.

The effective porosity of the tabular, siltstone aquifers is unknown, but it probably declines with depth because fewer fractures are present or in proximity to the diabase sill where the siltstones have been baked. The intervening shale beds are believed to have lower effective porosities than the siltstone units because they are less fractured.

Gerhart and Lazorchick (1988, table 16) assumed a specific yield of 0.007 for the lower layer.

Diabase Sill.-The diabase sill within the lower bedrock zone consists of slightly weathered to competent, but fractured, rock. This zone is bounded at the top by the upper highly weathered zone, which forms a confining layer, and grades with increasing depth into massive, impermeable rock. Water-bearing fractures are shallow and interconnection between secondary openings (even within the same borehole) is almost nonexistent. Estimated thickness of the lower bedrock zone is about $150 \mathrm{ft}$. In general, the diabase sill acts as a barrier to ground-water flow.

The hydraulic properties of the diabase for the area around well AD-343 are not known, but hydraulic conductivity and transmissivity from single-well aquifer tests in the diabase throughout Pennsylvania range from 0.00 to $170 \mathrm{ft} / \mathrm{d}$ and 0.24 to $930 \mathrm{ft}^{2} / \mathrm{d}$, respectively. Schreffler (1996), who studied the Coffman Hill diabase sheet in Bucks County, Pa., estimated transmissivity from slug tests as ranging from 4.2 to $440 \mathrm{ft}^{2} / \mathrm{d}$ and for openhole constant-discharge tests from 3.1 to $100 \mathrm{ft}^{2} / \mathrm{d}$.
Porosity and specific-yield estimates are not available but may be similar to that of granite or 0.1 and 0.09 percent, respectively (Heath, 1983).

\section{Recharge and Ground-Water Flow}

The average annual precipitation from 1872 to 1993 at the Eisenhower National Historic Site is 43.44 in. (National Oceanic and Atmospheric Administration, 1993); however, only a small part of this precipitation recharges ground water. Taylor and Royer (1981, p. 4) estimated that ground-water recharge averages only $7 \mathrm{in} / \mathrm{yr}$ for Adams County. R.E. Wright (1982) estimated the average annual recharge to the Brunswick Formation (laterally equivalent to the Gettysburg Formation) in the Delaware River Basin as 13.4 in. or $640,000(\mathrm{gal} / \mathrm{d}) / \mathrm{mi}^{2}$ and the 10-year, low-flow recharge as $7.4 \mathrm{in} / \mathrm{yr}$ or $350,000(\mathrm{gal} / \mathrm{d}) / \mathrm{mi}^{2}$. In their ground-water flow model, Gerhart and Lazorchick (1988, table 12) estimated average annual ground-water recharge as ranging from 2.6 to $9.1 \mathrm{in}$. for the Gettysburg area. These estimates were derived by varying recharge on the basis of lithology and precipitation during model calibration. Recharge may not be areally uniform because it is a function of lithology, soil type, soil moisture, temperature, slope, and other factors, including impervious surface area. For example, Schreffler (1996) reported the clay-rich soil and thin weathered bedrock zone of the Coffman Hill diabase sill in Bucks County, Pa., permitted very little recharge to the shallow ground-water system.

The time required for recharge to reach the lower bedrock zone is unknown but is likely to be highly variable, probably ranging from a few hours to years. For example, during the investigation of VOC contamination at well AD-652, approximately 500 gal of dye was pressure injected into the well at some depth below water surface. In a matter of a few hours or less, this dye was observed in a storm drain several blocks away from the injection site (R.W. Conger, U.S. Geological Survey, oral commun., 1998). Although this test does not simulate the conditions of natural ground-water recharge to the aquifer, it does indicate that the numerous shallow fractures in this well are in good hydraulic connection to the land surface. Nelms and Brockman (1997, figs. 2527) estimated recharge ages of 0-45 years for water from wells completed in the Culpeper Basin of Virginia, which contains rocks of similar age and lithology to those surrounding well AD-343. 
In general, the water table is a subdued reflection of topography. Water levels in topographically high areas generally are a little deeper (further from land surface) than water levels in topographic low areas such as valleys (table 6). Ground-water flow in the Gettysburg area is influenced by hydraulic head differences that are related to topographic position, pumping of public-supply wells AD-343 and AD-629, and anisotropy.

The ground-water levels used to draw the water-level contours on figure 11 were measured over a period of years from January 1973 through October 1997. Consequently, they represent water levels in different seasons, different climatic conditions, and different pumping conditions. Water levels in public-supply wells AD-343 and AD-629 were collected when the wells were under construction or undergoing maintenance and were not pumping. Water-level data from several wells in the study area indicate variability in water levels can be about $20 \mathrm{ft}$. Water levels measured in deep, open-borehole wells (table 29) probably represent a composite of the hydraulic head in multiple aquifers penetrated in each well. According to Becher (1989), however, the lack of measurable vertical movements of injected brine in deep wells suggests there is little difference in head among the tabular aquifers of the Gettysburg Formation that were penetrated by individual boreholes.

Becher (1989) measured water levels in about 60 wells in the vicinity of the Gettysburg National Military Park and Eisenhower National Historic Site. He observed that, in the area of the diabase sill, only minor declines in water level occurred between the spring and fall measurements. Becher (1989) put forth two theories: (1) only a small quantity of water can be discharged between spring and fall because the horizontal permeability of the diabase sill is low, or (2) a decline of only a few feet in water level is sufficient to trap any remaining water within the poorly connected fractures and joints of the competent bedrock zone of the diabase sill. Becher (1989) noted also that the natural ground- and surface-water flow tended to parallel the strike of bedding in the Gettysburg Formation.

The diabase dike west of Gettysburg and the diabase sill east and south of Gettysburg are topographic highs (surface-water divides) that also represent major ground-water divides (Becher, 1989, fig. 5). Ground water between these divides flows towards Rock Creek, the principal discharge point for ground water flowing through the upper and lower zones. Detailed information concerning ground-water flow to Rock Creek, however, is limited, and it was not possible to determine if Rock Creek is a gaining stream throughout its entire reach. Wood (1980, p. 18) reported there may be considerable lateral flow to points of discharge downstream from wells in valleys that have downward vertical flow. Although several springs and flowing wells have been reported, downward vertical head gradients are predominant in the area around Gettysburg and well AD-343.

Most active ground-water circulation in the Gettysburg area is probably in the upper highly weathered zone and the upper tens to several hundreds of feet in the lower bedrock zone. This natural circulation pattern, however, can be altered by heavy pumping. Becher (1989) noted pumping of Gettysburg Municipal Authority wells caused drawdown in wells at least $0.5 \mathrm{mi}$ away along strike. This anisotropy is the result of the dipping, tabular aquifers and the scarcity of secondary openings at depth. Ground-water flow in the direction perpendicular to dip is impeded relative to flow along strike. Because of this anisotropy, ground-water flow directions are not necessarily perpendicular to lines of equal hydraulic head, and ground-water flow directions are offset toward the strike direction. Elliptical cones of depression around pumped wells (such as seen in figure 11 at the $500 \mathrm{ft}$ contour interval between wells AD-174 and AD-629) indicate anisotropic hydraulic conductivity. Becher (1989, fig. 10) showed also that VOC's originally moving east, up dip, and roughly parallel to strike could possibly turn southward and be captured by wells operated by the Gettysburg Municipal Authority.

\section{Gettysburg Lowland - Abbottstown Well AD-717}

Abbottstown well AD-717 (locally called Production Well 6) is located just southwest of Abbottstown, Pa., in Berwick Township (fig. 14). The area in the vicinity of the well is characterized by residential, recreational (golf course), and agricultural land uses. The well is completed in the New Oxford Formation, which is moderately resistant to weathering, forming a gently rolling plain characterized by broad, shallow valleys and low, flat-topped ridges. About $0.75 \mathrm{mi}$ to the south and southwest of the Abbottstown well are the Pigeon Hills, which rise 400 to $600 \mathrm{ft}$ above the surrounding landscape. Two springs (including 

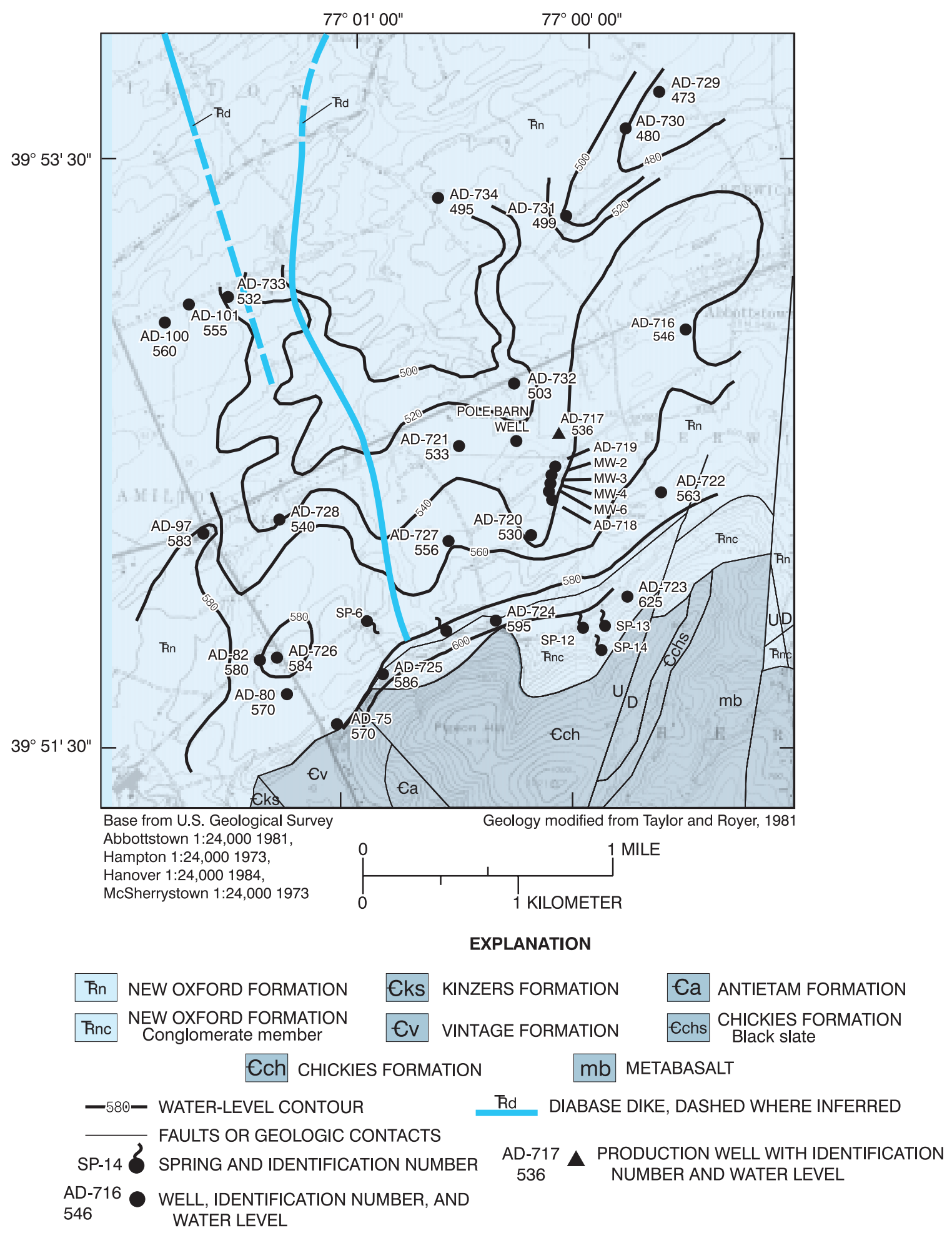

Figure 14. Location of well AD-717 and selected other wells, general geology, and water-level contours in the vicinity of Abbottstown, Pennsylvania. 
SP-6) are present southwest of Abbottstown near the base of Pigeon Hill. Three small springs (SP-12, SP-13, and SP-14) are present on Pigeon Hill and were formerly a source of water for the Borough of Abbottstown (fig. 14).

Abbottstown well AD-717 was reportedly drilled to a depth of $452 \mathrm{ft}$ bls. Water-bearing zones were penetrated at several depths from 90 to $345 \mathrm{ft}$ bls (table 33). The well is pumped on an intermittent schedule with a permitted pumping rate of $225 \mathrm{gal} / \mathrm{min}$.

\section{Conceptual Ground-Water Flow System Near Well AD-717}

A conceptual diagram of ground-water flow in the vicinity of well AD-717 was developed from published information describing general hydrogeologic conditions of fractured rock and unpublished information from the Abbottstown area, including drillers' logs (table 33), borehole geophysics, water levels, and aquifer tests. Much of the detailed discussion of hydrogeologic properties presented in this section was obtained from extensive site characterization work by R.E. Wright Associates, Inc. (1993a; 1994b), that was the result of a gasoline spill just west of well AD-717, and from a report describing a ground-water flow model of the Lower Susquehanna River Basin in Pennsylvania and Maryland (Gerhart and Lazorchick, 1988). A conceptual diagram of the hydrogeologic framework in the vicinity of well AD-717 is shown in figure 15 and described in the following sections.
In general, the hydrogeologic framework shows a heterogeneous, multiaquifer system of dipping geologic units within the New Oxford Formation that have differing hydrologic properties. An upper, highly weathered zone overlies a lower bedrock zone and truncates the dipping geologic units parallel to land surface.

\section{Upper Highly Weathered Zone}

The upper highly weathered zone of the New Oxford Formation consists of 10 to $50 \mathrm{ft}$ of relatively porous but poorly permeable clay rich regolith and shallow, weathered bedrock (where both are saturated). Soil drainage can be poor because of the abundance of low-permeability clay in the soil. In some highly weathered arkosic or subarkosic sandstones and conglomerates, clays produced by the alteration of feldspars can reduce the permeability of the rock or prevent any significant increase in permeability (Johnston, 1966, p. 16-19). Ground water is generally unconfined or semiconfined. Where the low permeability clays are absent, recharge can be rapid, as evidenced by rapid return to artesian conditions at wells AD-717 and AD-718 when they are not in use. Ground-water flow is probably influenced more strongly by the topography of the land surface and bedrock surface, depth of weathering, and lithology than by geologic structure; however, bedding can produce some anisotropic effects. The thickness of the highly weathered zone is generally greater beneath gentle slopes than beneath draws or valleys where surface water can remove weathered material (table 8). The upper, highly weathered zone is an important ground-water source to the lower

Table 33. Record of selected wells in the vicinity of Abbottstown, Pennsylvania

[Location of wells are shown in figure 14. Depth in feet below land surface; gal/min, gallons per minute; (gal/min)/ft, gallons per minute per foot of drawdown; ft, feet; --, not available; P, public; U, unused public; I, irrigation; M, monitor; NOXF, New Oxford Formation]

\begin{tabular}{|c|c|c|c|c|c|c|c|c|c|c|}
\hline $\begin{array}{c}\text { Well } \\
\text { number }\end{array}$ & $\begin{array}{l}\text { Well } \\
\text { depth }\end{array}$ & $\begin{array}{l}\text { Casing } \\
\text { length }\end{array}$ & $\begin{array}{l}\text { Reported } \\
\text { yield } \\
\text { (gal/min) }\end{array}$ & $\begin{array}{c}\text { Specific } \\
\text { capacity } \\
{[(\mathrm{gal} / \mathrm{min}) / \mathrm{ft}]}\end{array}$ & $\begin{array}{l}\text { Reported } \\
\text { depth to } \\
\text { water } \\
\text { (ft) }\end{array}$ & $\begin{array}{c}\text { Date } \\
\text { water level } \\
\text { measured }\end{array}$ & $\begin{array}{l}\text { Reported } \\
\text { depth to } \\
\text { water-bearing } \\
\text { zone } \\
\text { (ft) }\end{array}$ & $\begin{array}{l}\text { Water } \\
\text { use }\end{array}$ & $\begin{array}{c}\text { Depth to } \\
\text { bedrock } \\
(\mathrm{ft})\end{array}$ & Aquifer \\
\hline AD-716 & 504 & 66 & 158 & 0.34 & 24.5 & 09-11-1997 & $\begin{array}{c}68,85,142,242 \\
308,359,395\end{array}$ & $U$ & 29 & NOXF \\
\hline AD-717 & 452 & 62 & 300 & 1.5 & ${ }^{1} 107$ & 09-11-1997 & $\begin{array}{c}90,120,225,235 \\
280,330,345\end{array}$ & $P$ & 30 & NOXF \\
\hline AD-718 & 540 & 20 & 115 & -- & 276.5 & 09-11-1997 & $107,155,350,360$ & I & 10 & NOXF \\
\hline AD-719 & 350 & 67 & 120 & -- & 56.1 & 09-11-1997 & $\begin{array}{c}95,110,195, \\
276,320\end{array}$ & M & 45 & NOXF \\
\hline
\end{tabular}

\footnotetext{
${ }^{1}$ Well flows when not in use.

${ }^{2}$ Well flows during winter when not in use.
} 


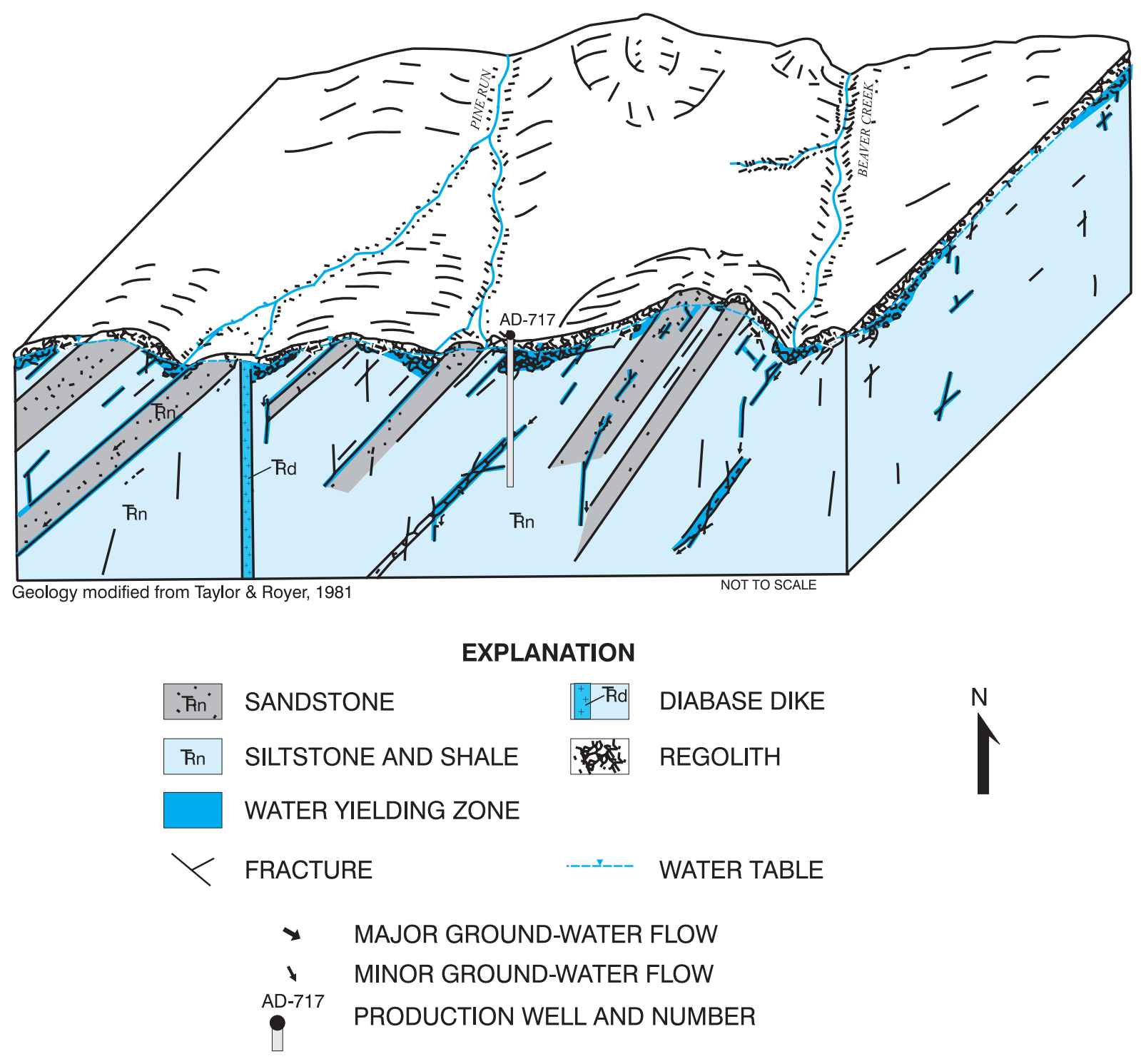

Figure 15. General geology and ground-water flow near Abbottstown, Pennsylvania, well AD-717. 
bedrock zone. Estimates of hydraulic conductivity and transmissivity of the upper, highly weathered zone are not available.

Specific yield, however, might be a reasonable estimate of effective porosity in the highly weathered zone. In Carol and Frederick Counties, Md., Meyer and Beall (1958) determined a specific yield of 0.001 for six wells completed in the New Oxford Formation. Gerhart and Lazorchick (1988, table 16) assumed that specific yield would be greater than the storage coefficient and used a specific yield of 0.007 for the lower bedrock zone.

\section{Lower Bedrock Zone}

The lower bedrock zone of the New Oxford Formation consists of competent, fractured siltstone and shale with interbeds of sandstone. Bedding is lenticular, and individual beds grade rapidly into rocks of different textures. Bedrock, exposed as part of the remedial action response to a gasoline spill, strikes north 65 degrees east and dips about 30 degrees to the northwest (R.E. Wright Associates, Inc., 1993a). Subvertical joints, dipping to the south, were noted by R.E. Wright Associates, Inc. (1993a), in the vicinity of monitor wells MW-2, MW-3, MW-4, MW-6, and AD-719 (fig. 14). The attitudes of these two joint sets are north 13 degrees east and north 64 degrees west.

Ground water in the study area is generally unconfined or semiconfined in the upper $100 \mathrm{ft}$ of the New Oxford Formation, especially where joints or fractures have been enlarged by weathering, but becomes confined in a down dip direction.

The water-bearing zones are commonly at lithologic contacts. Sandstone and conglomerate beds are generally more transmissive than shale or siltstone beds, especially in secondary openings such as bedding planes, fractures, and joints. With increased depth, bedding planes and joints probably close and high-angle fractures become dominant and can facilitate movement of water across rock layers, thus serving as a major hydraulic connection between bedding-plane fractures (fig. 15). Most beds are lenticular, erratically spaced, and dip 15-40 degrees to the northwest (Wood and Johnston, 1964). The suite of geophysical logs for well AD-716 (fig. 16) and drillers' logs for other wells (table 33) indicate water-bearing fractures are encountered to a depth of about $400 \mathrm{ft}$.
Well AD-716 was determined to be an appropriate well to log in the study of the Abbottstown well field because it is (1) in close proximity to well AD-717, (2) is about the same depth, (3) was completed in the same geologic formation, and (4) is located nearly on strike with well AD-717. The borehole caliper log for well AD-716 shows the total depth of the borehole is $504 \mathrm{ft}$ and it is cased with 8-in.-diameter casing to $66 \mathrm{ft}$ bls (fig. 16). The caliper log shows major fractures at $137,140-155$, and $358 \mathrm{ft}$ bls plus additional smaller fractures throughout the borehole. At a depth of $370 \mathrm{ft}$, the driller changed from an 8-in. diameter drill bit to a 6-in. diameter drill bit. Under nonpumping conditions, the fluidresistivity log shows a change in slope at $396 \mathrm{ft}$ bls that corresponds to a sharp break in slope on the fluid-temperature $\log$ and a driller reported waterbearing zone (table 33). The gamma log indicates rapid lithologic changes between thin sandstone and siltstone and(or) shale beds. The heatpulseflowmeter measurements indicate ground-water flow is downward. The heatpulse flowmeter measured downward flow at 115, 130, 160, 230, 270 , and $320 \mathrm{ft}$ bls and no flow at 80,364 , and $380 \mathrm{ft}$ (table 34). Most water enters the borehole at the minor fractures around $90 \mathrm{ft}$ and the major fractures at 137 and 140-154 ft bls. The water then exits the borehole through the major fracture at $358 \mathrm{ft}$ bls. Additional water enters the borehole at $396 \mathrm{ft}$ bls; however, the direction of vertical borehole flow was not determined. On the basis of a review of well AD-716 cuttings from 5-ft intervals, R.E. Wright Associates, Inc. (1993a), noted the reported water-bearing zones were at lithologic and color changes.

Information on the aquifer properties of the lower bedrock zone of the New Oxford Formation in and around well AD-717 are limited. Estimates of transmissivity by Larry Taylor (HydroScience, Inc., written commun., 1998) from the pumping of well AD-717 are presented in table 35; the median is $917 \mathrm{ft}^{2} / \mathrm{d}$. Wood and Johnston (1964, table 6) estimated the transmissivities of nine single-well aquifer tests in the lower bedrock zone of the New Oxford Formation in Adams and York Counties ranged from 0.936 to $695 \mathrm{ft}^{2} / \mathrm{d}$; the median was $46.8 \mathrm{ft}^{2} / \mathrm{d}$. Median hydraulic conductivity and transmissivity (D. J. Low and others, U.S. Geological Survey, written commun., 1998), on the basis of 89 single-well aquifer tests in the lower 

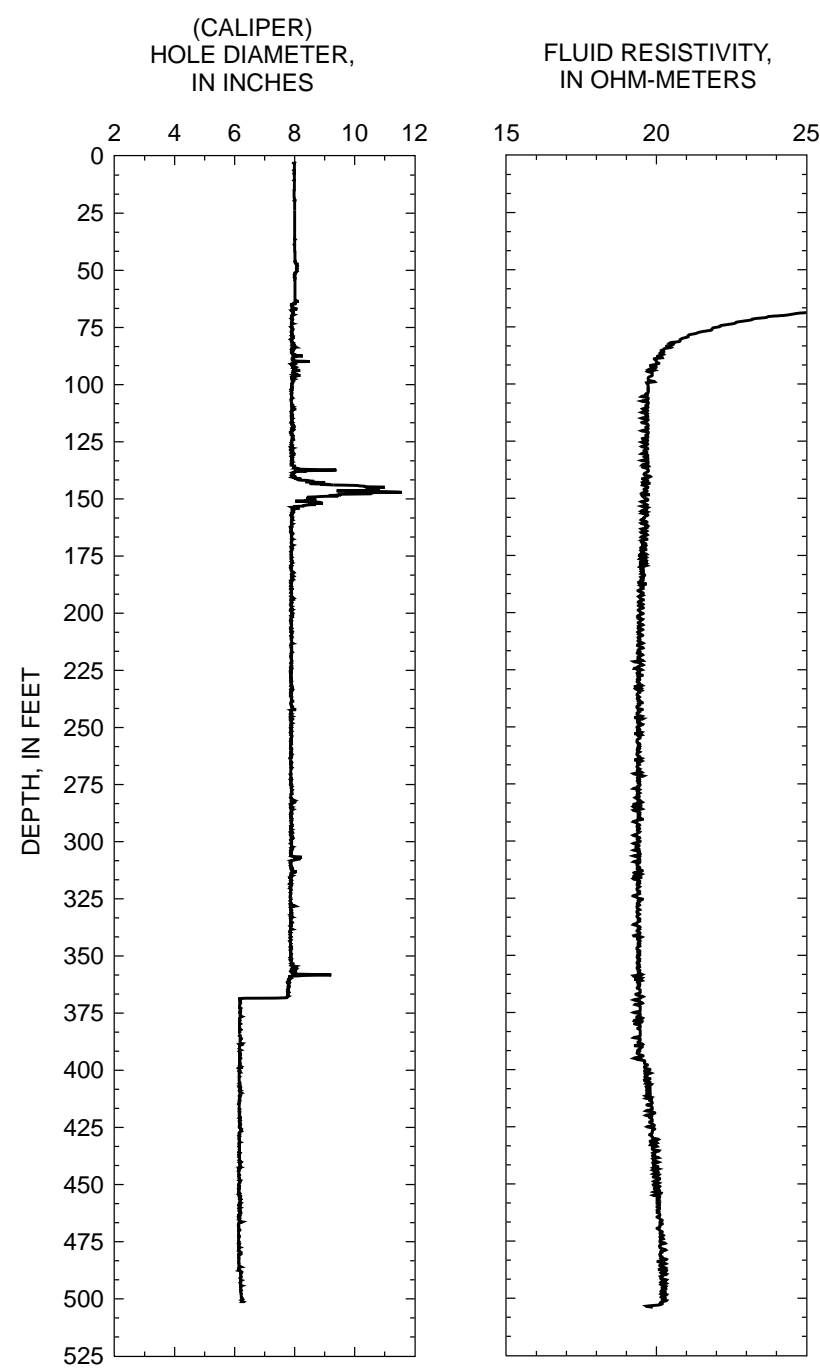

NATURAL GAMMA, UNTS PER SECOND
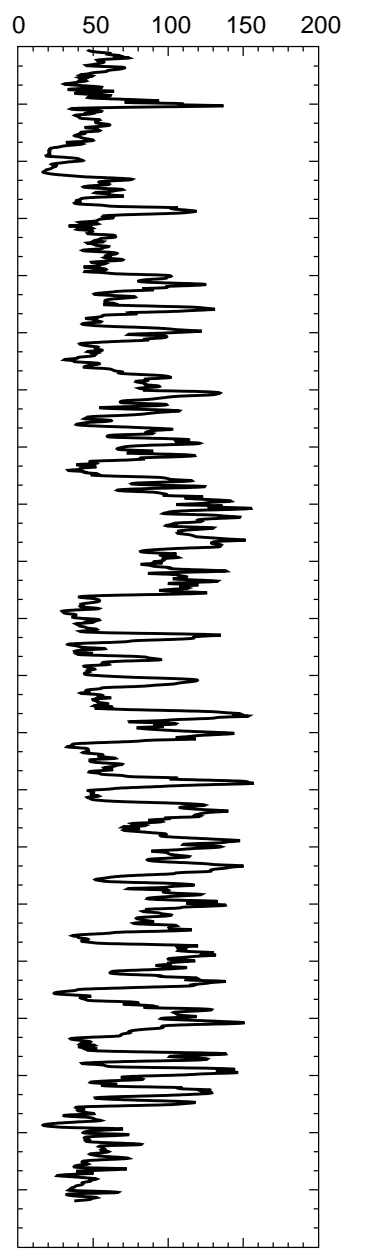

SINGLE-POINT

$\begin{array}{lll}0 & 500 & 1,000\end{array}$

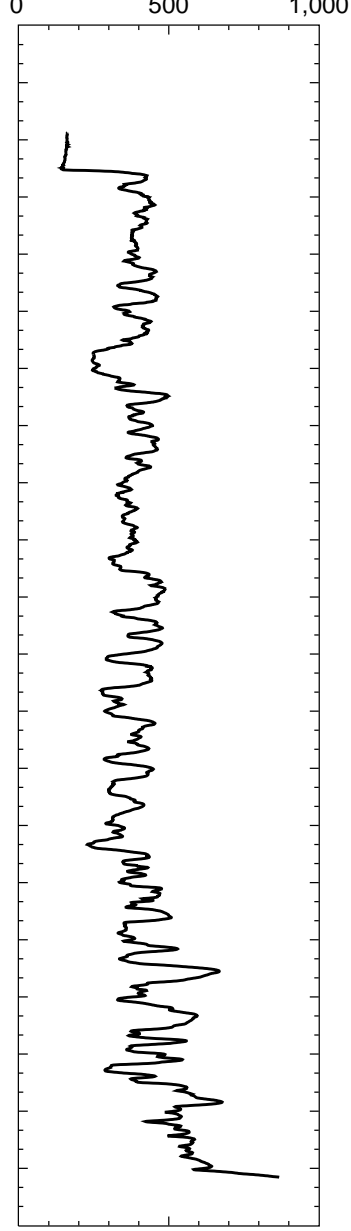

FLUID TEMPERATURE, IN DEGREES CELSIUS

10

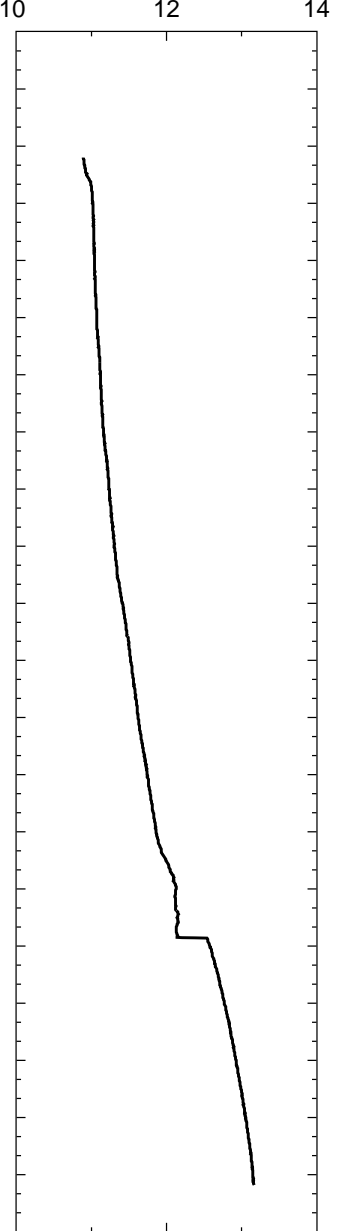

Figure 16. Borehole geophysical logs for borehole AD-716, September 18, 1997. 
bedrock zone of the New Oxford Formation, are $0.68 \mathrm{ft} / \mathrm{d}$ and $97 \mathrm{ft}^{2} / \mathrm{d}$, respectively (table 36 ).

Hydraulic conductivity and transmissivity were calculated from 1 hour or longer, single-well aquifer tests or specific-capacity tests by use of a modified Theis formula (Theis and others, 1963).
Gerhart and Lazorchick (1988, table 8) used a hydraulic conductivity of $2.67 \mathrm{ft} / \mathrm{d}$ for the lower bedrock zone near Abbottstown, Pa.

Effective porosity and specific yield of poorly cemented sandstone or conglomerate beds at this site are not known. Well-cemented, sandstone

Table 34. Summary of heatpulse-flowmeter measurements for Abbottstown, Pennsylvania, well AD-7163

$[--$, not applicable]

\begin{tabular}{ccc}
\hline $\begin{array}{c}\text { Depth } \\
\text { feet below } \\
\text { land surface) }\end{array}$ & $\begin{array}{c}\text { Flow rate under } \\
\text { ambient conditions } \\
\text { (gallons per minute) }\end{array}$ & $\begin{array}{c}\text { Flow direction } \\
\text { under ambient } \\
\text { conditions }\end{array}$ \\
\hline 80 & no flow & -- \\
115 & 0.6 & Down \\
130 & .5 & Down \\
160 & .9 & Down \\
230 & 1.0 & Down \\
270 & 1.0 & Down \\
320 & .99 & Down \\
364 & no flow & -- \\
380 & no flow & -- \\
\hline
\end{tabular}

Table 35. Summary of hydraulic properties from the 72-hour multiple-well aquifer test of Abbottstown, Pennsylvania, well AD-717

[Data from R.E. Wright Associates, Inc., 1994b; transmissivity and storativity determined by Larry Taylor, HydroScience, Inc., written commun., 1998; --, not applicable]

\begin{tabular}{|c|c|c|}
\hline Well number & $\begin{array}{c}\text { Transmissivity } \\
\text { (square feet per day) }\end{array}$ & Storativity \\
\hline AD-717 & 331 & -- \\
\hline AD-718 & 4,760 & 0.001 \\
\hline AD-719 & 756 & .000003 \\
\hline Pole barn & 1,960 & .0002 \\
\hline MW-3 & 917 & .001 \\
\hline MW-4 & 1,370 & .001 \\
\hline MW-6 & 1,370 & .001 \\
\hline Distance drawdown to AD-718 & 508 & .001 \\
\hline Distance drawdown to Pole barn & 528 & .0007 \\
\hline
\end{tabular}

Table 36. Hydraulic conductivity and transmissivity from single-well aquifer tests or specific-capacity tests in the New Oxford Formation throughout Pennsylvania

[Note: Hydraulic conductivity and transmissivity were calculated from specific-capacity tests by the method of Theis and others, 1963 using a specific yield of 0.007 ; $\mathrm{ft} / \mathrm{d}$, feet per day; $\mathrm{ft}^{2} / \mathrm{d}$, feet squared per day]

\begin{tabular}{|c|c|c|c|c|c|c|c|c|}
\hline \multirow{2}{*}{$\begin{array}{l}\text { Hydraulic } \\
\text { property }\end{array}$} & \multirow{2}{*}{$\begin{array}{l}\text { Number } \\
\text { of wells }\end{array}$} & \multicolumn{5}{|c|}{$\begin{array}{l}\text { Percentage of samples in which } \\
\text { value was equaled or exceeded }\end{array}$} & \multirow{2}{*}{ Minimum } & \multirow{2}{*}{ Maximum } \\
\hline & & 90 & 75 & $\begin{array}{c}50 \\
\text { (median) }\end{array}$ & 25 & 10 & & \\
\hline Hydraulic conductivity (ft/d) & 89 & 0.09 & 0.17 & 0.68 & 1.7 & 5.3 & 0.02 & 76 \\
\hline Transmissivity $\left(\mathrm{ft}^{2} / \mathrm{d}\right)$ & 89 & 11 & 35 & 97 & 250 & 760 & 1.0 & 5,800 \\
\hline
\end{tabular}


and conglomerate beds, as well as shale and siltstone beds, will have considerably lower effective porosity than the upper, highly weathered zone.

\section{Recharge and Ground-Water Flow}

The average annual precipitation from 1904 to 1988 at Hanover, Pa., is 40.00 in. (National Oceanic and Atmospheric Administration, 1988); however, only a small part of this recharges ground water. Taylor and Royer (1981, p. 4) estimated groundwater recharge is only $7 \mathrm{in} / \mathrm{yr}$ in Adams County. Gerhart and Lazorchick (1988, table 12) estimated average annual ground-water recharge as ranging from 7.2 to 8.4 in. R.E. Wright (1993b) estimated recharge to the New Oxford Formation as 8.6 in/yr or $410,000(\mathrm{gal} / \mathrm{d}) / \mathrm{mi}^{2}$ during normal conditions and $4.6 \mathrm{in} / \mathrm{yr}$ or $220,000(\mathrm{gal} / \mathrm{d}) / \mathrm{mi}^{2}$ under drought conditions.

The time required to recharge the lower bedrock zone is unknown but is likely to be highly variable, probably ranging from a few hours to years. Nelms and Brockman (1997, fig. 25-26) estimated recharge ages of 0-45 years for water from wells completed in the Culpeper Basin of Virginia, which contains rocks of similar age and lithology as those surrounding well AD-717.

In general, the water table is a subdued reflection of topography (fig. 14). The Pigeon Hill area is a topographic high that represents a major surface-water and ground-water divide in the immediate area of well AD-717. Smaller hills and ridges are local divides that strongly influence the direction of ground-water flow in the upper layer. In general, ground water flows downward from topographic highs towards well AD-717. On the basis of available water-level data, the diabase dike west of well AD-717 does not function as a major ground-water or surface-water divide.

As seen in figure 14, heavy pumping of well AD-717 has not created a noticeable effect on water-level contours. Although not defined, the cone of depression around well AD-717 will be somewhat elongate in a northeast to southwest direction, approximately parallel to strike. However, with heavy pumping from wells AD-718 and AD-719, overlapping north to south cones of depression may be established that will encompass all three high-capacity wells.

Most active ground-water circulation in the Abbottstown area probably is in the upper highly weathered zone and the upper tens to several hundreds of feet in the lower bedrock zone. Water contribution to surface discharge points such as Pine Run, Beaver Creek, and the springs by the lower bedrock zone are probably negligible.

Springs SP-12, SP-13, and SP-14 are the natural discharge points for ground-water flowing through the upper part of the Pigeon Hill area and the upper, highly weathered zone of the New Oxford Formation. Spring SP-6 and the unnamed spring are located either at lithologic contacts or faults that serve as conduits for ground-water flow from the lower layer. Wells such as AD-717 and AD-718, which are artesian under nonpumping conditions, represent short circuits in the groundwater flow system. These wells intercept groundwater flow from the lower bedrock layer that has migrated down dip from the Pigeon Hill area along any number of secondary openings.

Drawdown data from pumping of well AD-717 (table 37) indicates the New Oxford Formation is only slightly anisotropic, generally elongate and parallel to formational contacts (R.E. Wright Associates, Inc., 1994b). Drawdown in observation well AD-719 was probably fracture or joint related. Other wells located along the same fracture trace (R.E. Wright Associates, Inc., 1993a, fig. 3; R.E. Wright Associates, Inc., 1994b, fig. 1 and table 5-1) exhibited considerably less drawdown than observed in well AD-719.

Table 37. Summary of water-level measurements of a 72-hour aquifer test for Abbottstown, Pennsylvania, well $A D-717$

[Data from R.E. Wright Associates, Inc., 1994b]

\begin{tabular}{lccc}
\hline $\begin{array}{c}\text { Well } \\
\text { number }\end{array}$ & $\begin{array}{c}\text { Drawdown at } \\
\text { end of test } \\
\text { (feet below } \\
\text { land surface) }\end{array}$ & $\begin{array}{c}\text { Distance from } \\
\text { pumping well } \\
\text { (feet) }\end{array}$ & $\begin{array}{c}\text { Projected 90-day } \\
\text { drawdown } \\
\text { (feet) }\end{array}$ \\
\hline AD-717 & 113 & 0 & 126 \\
AD-719 & 21.8 & 810 & 30.5 \\
MW-3 & 5.3 & 1,020 & 17.7 \\
MW-4 & 4.2 & 1,310 & 12.7 \\
MW-6 & 3.6 & 1,380 & 12.2 \\
AD-718 & 2.4 & 1,670 & 5.4 \\
Pole Barn & 4.8 & 1,590 & 9.8 \\
\hline
\end{tabular}

\section{Blue Ridge - Fairfield Well AD-754}

Fairfield well AD-754 is about 2 mi west of Fairfield, Pa., in Hamiltonban Township (fig. 17). The area around the well is very rugged; vertical relief exceeds $800 \mathrm{ft}$. Land use is dominated by forest; residential and agricultural land uses are 


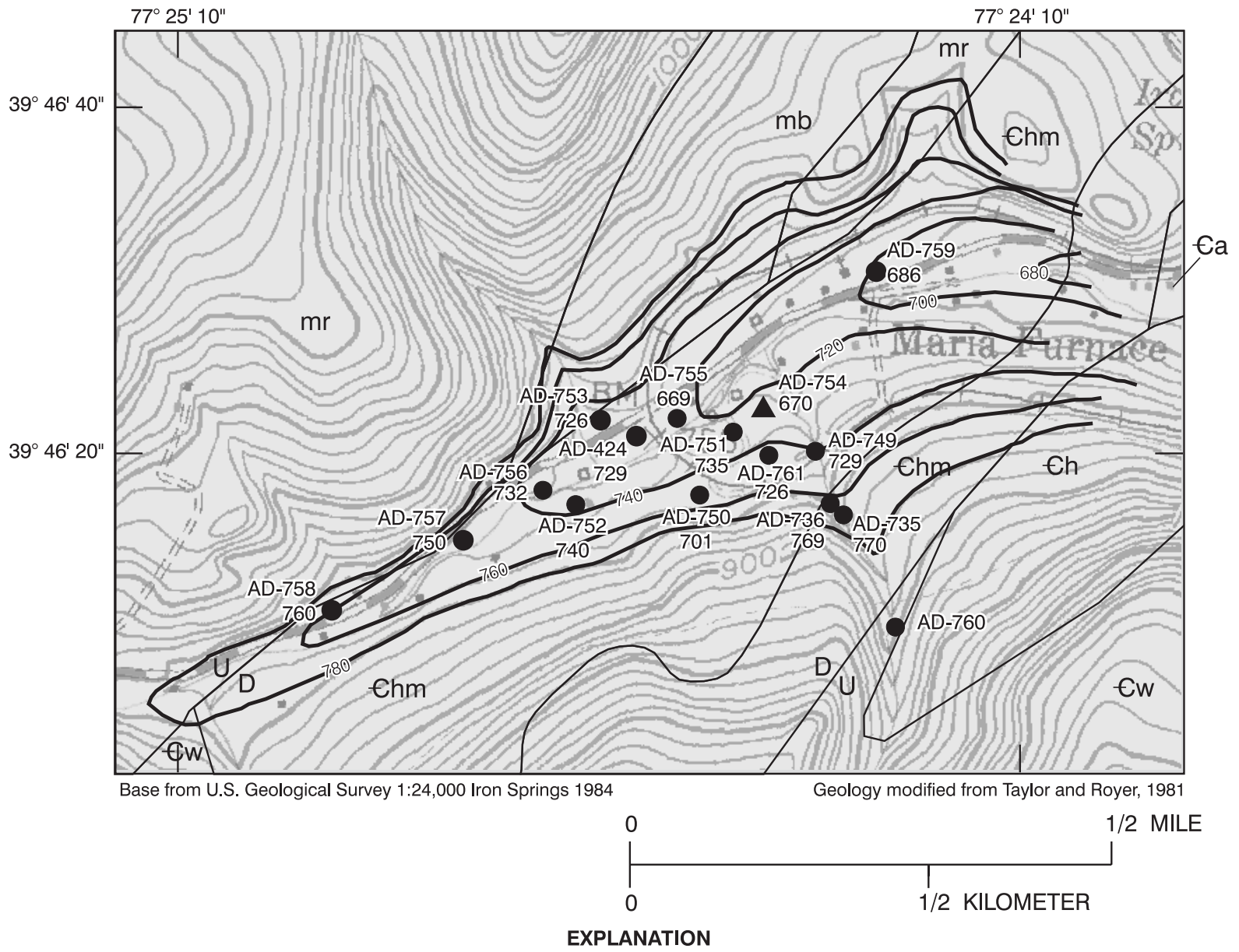

\begin{tabular}{|c|c|c|c|c|c|}
\hline$\epsilon a$ & \multicolumn{3}{|c|}{ ANTIETAM FORMATION } & Ew & WEAVERTON FORMATION \\
\hline$€ \mathrm{Enm}$ & \multicolumn{3}{|c|}{ MONTALTO MEMBER } & $\mathrm{mb}$ & METABASALT \\
\hline Ch & \multicolumn{3}{|c|}{ HARPERS FORMATION } & $\mathrm{mr}$ & METARHYOLITE \\
\hline \multirow[b]{3}{*}{$\begin{array}{l}\text { AD-736 } \\
769\end{array}$} & \multicolumn{5}{|c|}{ FAULT OR GEOLOGIC CONTACT } \\
\hline & \multicolumn{5}{|c|}{ WATER LEVEL CONTOUR } \\
\hline & \multicolumn{5}{|c|}{ WELL, IDENTIFICATION NUMBER, AND WATER LEVEL } \\
\hline $\begin{array}{l}\text { AD-754 } \\
670\end{array}$ & \multicolumn{5}{|c|}{$\begin{array}{l}\text { PRODUCTION WELL, IDENTIFICATION NUMBER, } \\
\text { AND WATER LEVEL }\end{array}$} \\
\hline
\end{tabular}

Figure 17. Location of well AD-754, selected other wells, general geology, and water-level contours in the vicinity of Fairfield, Pennsylvania. 
small in comparison. The Harpers Formation, which immediately underlies much of the well field, is moderately resistant to weathering, forming narrow, steep-sided valleys. The metarhyolite and metabasalt, which border or underlie the Harpers Formation, are very resistant to weathering and form the core of South Mountain.

The Fairfield well field consists of two wells, wells AD-736 and AD-750 (locally known as FMA Wells 9 and 10, respectively), that are not presently pumped. Wells AD-754 (FMA Well 4) and AD-751 (FMA Well 5) are pumped on alternating 12-hour as-needed schedules. A number of other public supply wells are currently unused (table 38).

\section{Conceptual Ground-Water Flow System near Well AD-754}

A conceptual diagram of ground-water flow in the vicinity of well AD-754 was developed from published information describing the general hydrogeologic conditions of the South Mountain area and unpublished information including drillers' logs (table 38), borehole geophysics, water levels, and aquifer tests. Much of the detailed discussion of hydrogeologic proper-ties presented in this section was based on work conducted by consultants (Meisler and Earl, Inc., 1991; Peffer
Geotechnical Corp., 1996) during the drilling, constructing, and development of a number of wells listed in table 38 .

A conceptual diagram of the hydrogeologic framework in the vicinity of the Fairfield well field is shown in figure 18 and is described in the following sections. In general, the framework shows a heterogeneous fractured bedrock aquifer whose upper part is truncated by a zone of regolith and highly weathered bedrock that lies parallel to land surface.

\section{Upper Highly Weathered Zone}

The upper, highly weathered zone consists of about 10 to $60 \mathrm{ft}$ or more of sandy silt and gravel colluvium or clay and weathered bedrock (where both are saturated). Alluvial soil with sandy silt to silty sand matrix and boulders is present in and along Toms Creek (Peffer Geotechnical Corp., 1996). Ground water is unconfined, and recharge is rapid. This flow system is influenced more strongly by the topography of the land surface and bedrock surface than by geologic structure; however, jointing, bedding planes, and structural dip can locally redirect the horizontal groundwater flow component of this layer. The upper, highly weathered zone is an important water source for the underlying more competent bedrock. Where thicker, such as in stream valleys or colluvial aprons, the highly weathered zone can

Table 38. Record of selected wells in the vicinity of Fairfield, Pennsylvania

[Location of wells are shown in figure 17. Depth in feet below land surface; gal/min, gallons per minute; (gal/min)/ft, gallons per minute per foot of drawdown; --, not available; P, public; U, unused public; D, domestic; HRPR, Harpers Formation; MTRL, metarhyolite; MBSL, metabasalt]

\begin{tabular}{|c|c|c|c|c|c|c|c|c|c|c|}
\hline $\begin{array}{c}\text { Well } \\
\text { number }\end{array}$ & $\begin{array}{l}\text { Well } \\
\text { depth }\end{array}$ & $\begin{array}{l}\text { Casing } \\
\text { length }\end{array}$ & $\begin{array}{l}\text { Reported } \\
\text { yield } \\
\text { (gal/min) }\end{array}$ & $\begin{array}{c}\text { Specific } \\
\text { capacity } \\
{[(\mathrm{gal} / \mathrm{min}) / \mathrm{ft}]}\end{array}$ & $\begin{array}{c}\text { Reported } \\
\text { depth to } \\
\text { water } \\
\text { (ft) }\end{array}$ & $\begin{array}{c}\text { Date } \\
\text { water level } \\
\text { measured }\end{array}$ & $\begin{array}{l}\text { Reported } \\
\text { depth to } \\
\text { water-bearing } \\
\text { zones } \\
\text { (ft) }\end{array}$ & $\begin{array}{c}\text { Water } \\
\text { use }\end{array}$ & $\begin{array}{l}\text { Depth to } \\
\text { bedrock } \\
(\mathrm{ft})\end{array}$ & Aquifer \\
\hline AD-424 & 80 & 20 & 16 & 0.38 & 6 & 04-00-1979 & 64 & $\mathrm{D}$ & 18 & MBSL \\
\hline AD-735 & 341 & 30 & 12 & -- & 29.70 & 09-25-1997 & 135,262 & $U$ & 18 & HRPR \\
\hline AD-736 & 500 & 40 & 30 & .38 & 21.30 & 09-25-1997 & $90,200,260$ & $U$ & 20 & HRPR \\
\hline AD-749 & 320 & 40 & 2 & -- & 30.70 & 09-25-1997 & 145 & $U$ & 9 & HRPR \\
\hline AD-750 & 401 & 59 & 150 & .62 & 68.55 & 09-25-1977 & $180,300,335,360,375$ & $U$ & 30 & $\begin{array}{l}\text { HRPR (minor) } \\
\text { MTRL (major) }\end{array}$ \\
\hline AD-751 & 420 & 33 & 30 & .21 & 100 & 09-26-1997 & $190,205,260,275$ & $\mathrm{P}$ & 10 & MTRL and MBSL \\
\hline AD-752 & 75 & 51 & 25 & 2.5 & 10 & 02-00-1989 & 60,70 & D & 46 & MRTL \\
\hline AD-754 & 345 & 42 & 150 & 1.0 & 70 & 09-26-1997 & $160,265,320,325$ & $\mathrm{P}$ & 10 & $\begin{array}{l}\text { HRPR (minor) } \\
\text { MTRL (major) }\end{array}$ \\
\hline AD-755 & 306 & 24 & 60 & 1.5 & 61.05 & 09-29-1997 & $140,260,265$ & D & -- & MTRL \\
\hline AD-756 & 125 & 36 & 60 & 4 & 7.6 & 09-29-1997 & 80,100 & D & 31 & MTRL \\
\hline AD-760 & 301 & 28 & 5 & -- & -- & -- & $54,65,191$ & $U$ & 17 & HRPR \\
\hline AD-761 & 300 & 30 & .25 & .001 & 34.36 & 09-25-1997 & -- & U & 25 & HRPR \\
\hline
\end{tabular}



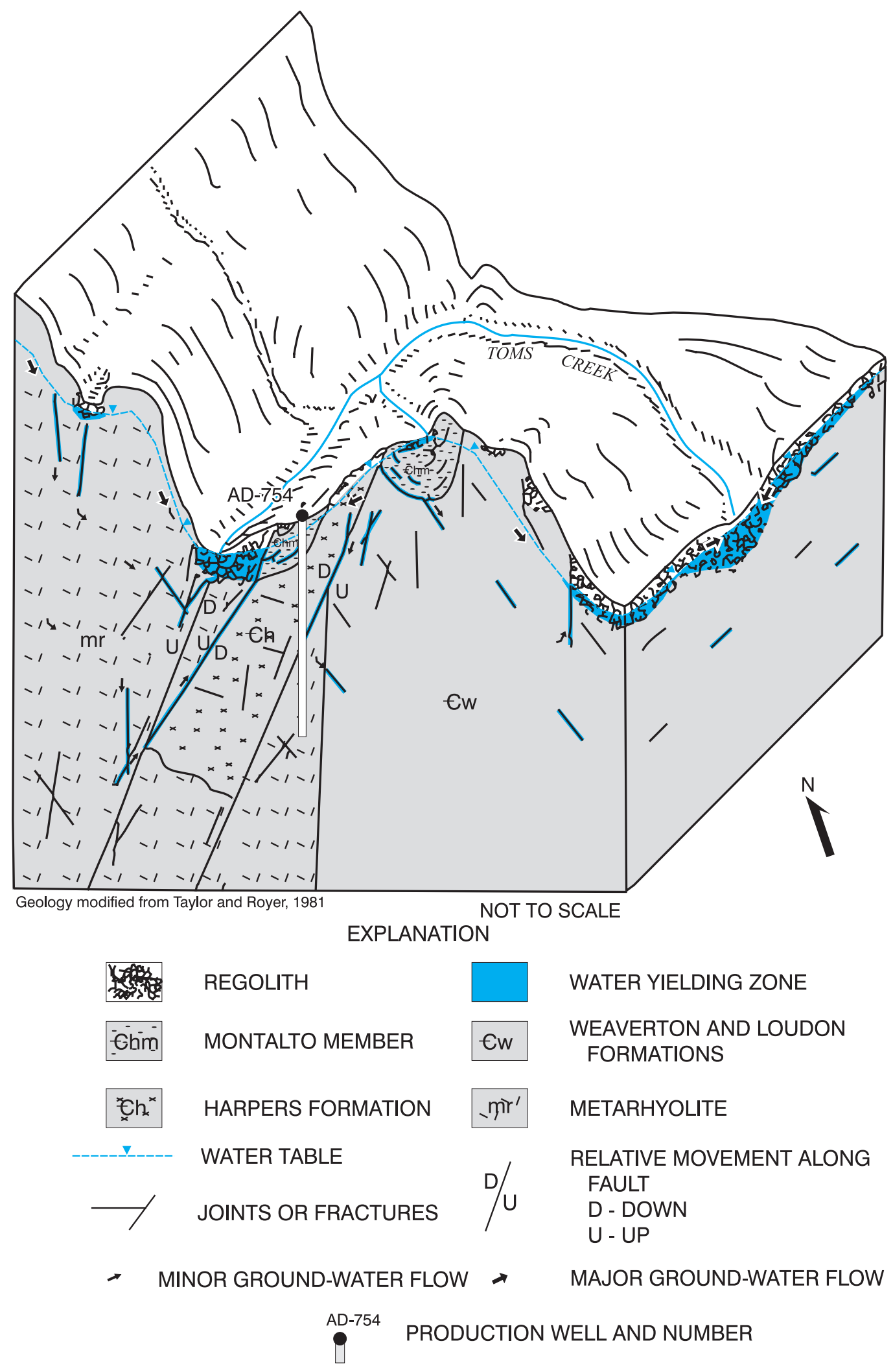

Figure 18. General geology and ground-water flow near Fairfield, Pennsylvania, well AD-754. 
provide sustained long-term recharge to the lower bedrock zone. Hydraulic conductivity is expected to range from 1 to $1,000 \mathrm{ft} / \mathrm{d}$, and transmissivity ranges from 10 to $60,000 \mathrm{ft}^{2} / \mathrm{d}$ (Dennis J. Low and others, U.S. Geological Survey, written commun., 1998). No information is available regarding the effective porosity of the upper, highly weathered zone.

\section{Lower Bedrock Zone}

The lower bedrock zone consists of competent, fractured bedrock. Because of the high topographic relief, the flow system is strongly affected by topographic setting. According to Peffer Geotechnical Corp. (1996), cleavage is the dominant structural element in the Harpers Formation and the metarhyolite. Cleavage in the Harpers Formation trends generally northeast to southwest with a moderate (47-67 degree) southeast dip. In the metarhyolite, cleavage trends north northeast to south southwest with a moderate (54 degree) dip to the east southeast (Fauth, 1978). Toms Creek (figs. 17 and 18) parallels a normal fault that dips to the southeast beneath the well field (Taylor and Royer, 1981; Fauth, 1978). Several wells (AD-750, AD-751, AD-754,) have been drilled through the Harpers Formation into the underlying metarhyolite beneath the fault.

Ground water is generally unconfined or semiconfined at shallow depths but becomes confined as it moves to greater depths along secondary openings such as cleavage planes, fractures, and faults. Pumping of well AD-750 established a cone of depression that was generally parallel to the north northeast-south southwest strike of the cleavage planes in the metarhyolite (Peffer Geotechnical Corp., 1996). Normal cyclic pumping of wells AD-754 and AD-751 exhibit a similar orientation to their cones of depression (Peffer Geotechnical Corp., 1996). This suggests the cleavage planes generally are well connected and are responsible for much of the anisotropy that Meisler and Earl, Inc. (1991), and Peffer Geotechnical Corp. (1996) observed at the well field. On the basis of the drawdown data for the pumping test of well AD-736, Peffer Geotechnical Corp. (1996) suggests the bedrock aquifer near this well is dominated by flow in discrete fractures. This also suggests the fractures at the well field are not well connected and may not serve as the principal pathways for ground-water recharge. Other lithologic contacts and faults are probably common but minor sources of water.
Borehole geophysical logging of well AD-750 indicates ground-water flow is complex (fig. 19). The caliper log shows the total depth of the borehole is $401 \mathrm{ft}$ and it is cased with 8-in.-diameter casing to $59 \mathrm{ft}$. The caliper log shows major fractures at 59-66, 178-179, 219-221, 274, and 363-365 ft bls plus additional smaller fractures throughout the borehole. Under nonpumping conditions, the fluid-temperature and fluid-resistivity logs from well AD-750 show considerable deflections in slope at depths of 179 and $361 \mathrm{ft}$ that closely correspond to major fractures identified on the caliper log (fig. 19). The natural gamma and single-point resistance logs exhibit marked changes at $276 \mathrm{ft}$ bls that correspond to the lithologic contact between the Harpers Formation and the metarhyolite. The heatpulse flowmeter measured no flow from 86 to $170 \mathrm{ft}$ bls, downward flow from 188 to $330 \mathrm{ft}$ bls, and upward flow at 350 and $376 \mathrm{ft}$ bls (table 39). Most water enters the borehole through fractures at about $178-179 \mathrm{ft}$ and below $350 \mathrm{ft}$. The water moves vertically and exits the hole through the minor fracture at 336-338 ft bls. The heatpulseflowmeter measurements indicate the contact between the Harpers Formation and the metarhyolite at a depth of $276 \mathrm{ft}$ is not a source of water under nonpumping conditions. The results of these efforts indicate ground-water movement is present at a depth of at least $376 \mathrm{ft}$ bls in some places (table 39).

Meisler and Earl, Inc. (1991), and Peffer Geotechnical Corp. (1996) conducted long term (48-49 hour) aquifer tests on wells AD-751, AD-754, AD-736, and AD-750. The aquifer tests indicated that (1) the Harpers Formation has hydraulic conductivity and transmissivity considerably lower than in the metarhyolite or metabasalt (tables 40 and 41), (2) the Harpers Formation, metabasalt, and metarhyolite behave as confined or semiconfined aquifers, (3) the metarhyolite is anisotropic with the greatest transmissivity parallel to bedrock cleavage, (4) the hydrologic connection between the Harpers Formation and the metarhyolite or metabasalt is poor, and (5) pumping of well AD-750 will interfere with the pumping of wells AD-754 and AD-751.

Effective porosity of the Harpers Formation, metarhyolite, and metabasalt at this site are not known. The presence of abundant cleavage planes in the metarhyolite favors an effective porosity greater than in the Harpers Formation. 

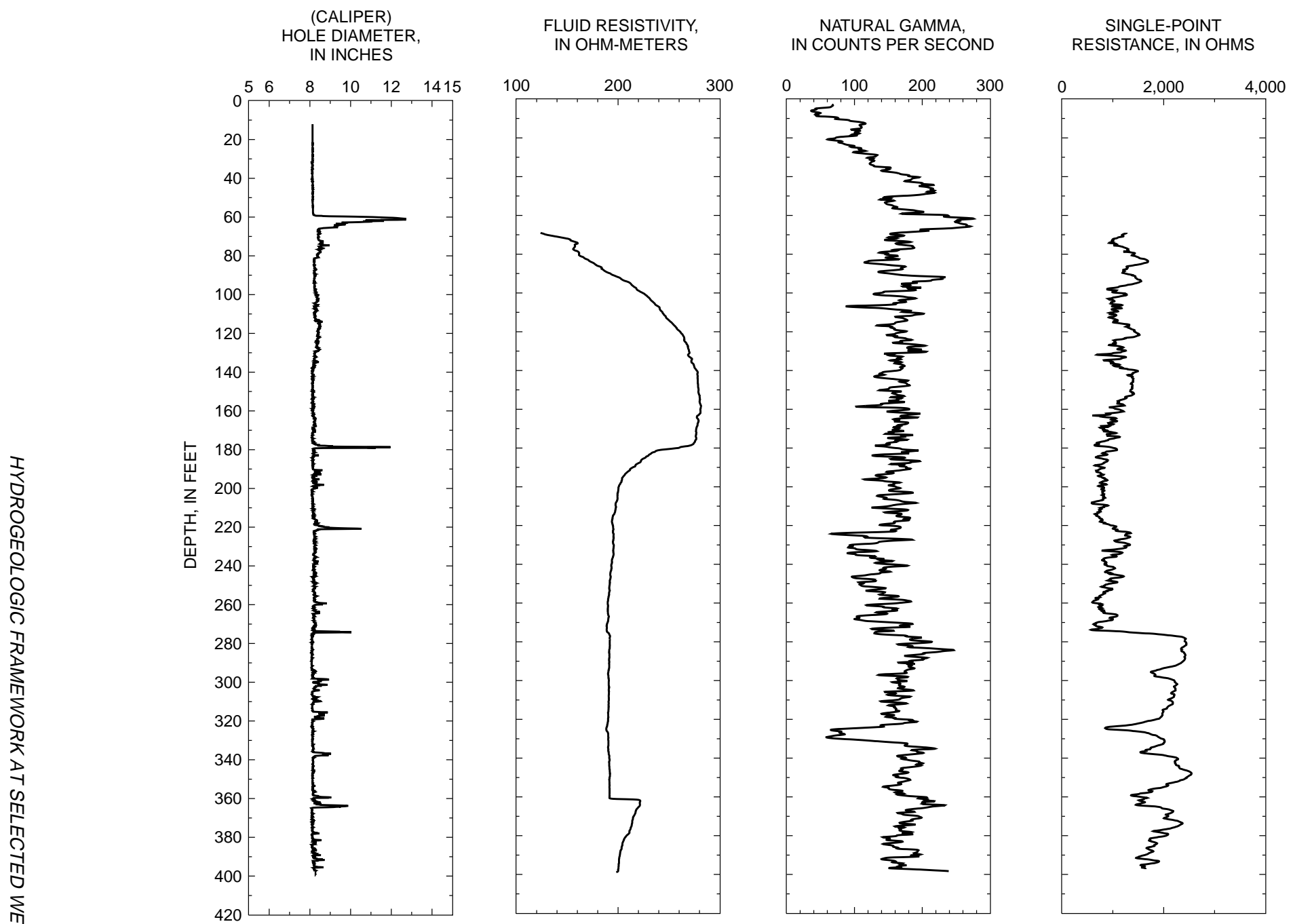

\section{FLUID TEMPERATURE, IN DEGREES CELSIUS}

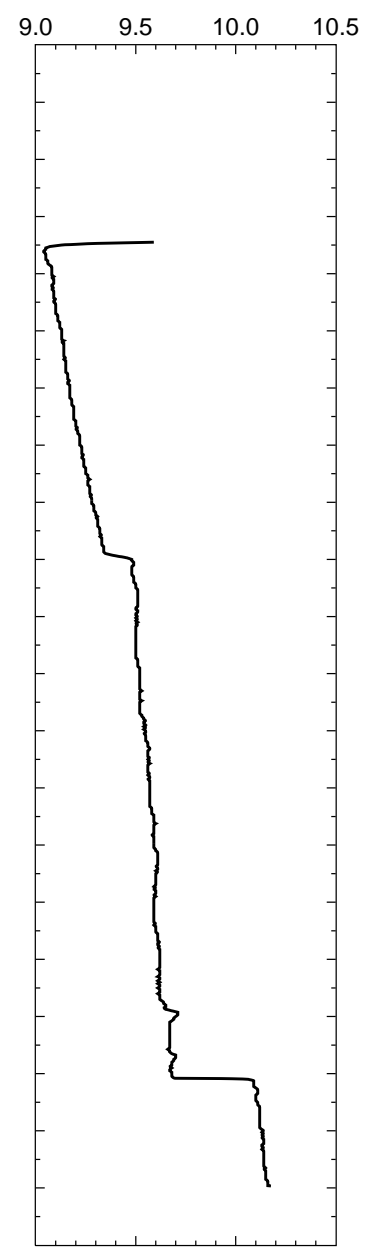

Figure 19. Borehole geophysical logs for borehole AD-750, September 25, 1997. 
Table 39. Summary of heatpulse-flowmeter measurements for Fairfield, Pennsylvania, well $A D-750$

[--, not applicable]

\begin{tabular}{ccc}
\hline $\begin{array}{c}\text { Depth } \\
\text { feet below } \\
\text { land surface) }\end{array}$ & $\begin{array}{c}\text { Flow rate under } \\
\text { ambient conditions } \\
\text { (gallons per minute) }\end{array}$ & $\begin{array}{c}\text { Flow direction under } \\
\text { ambient conditions }\end{array}$ \\
\hline 86 & no flow & -- \\
110 & no flow & -- \\
124 & no flow & -- \\
150 & no flow & -- \\
170 & no flow & -- \\
188 & 0.56 & Down \\
204 & .56 & Down \\
250 & .52 & Down \\
290 & .54 & Down \\
330 & .37 & Down \\
350 & .85 & Up \\
376 & .24 & Up \\
\hline
\end{tabular}

Table 40. Summary of hydraulic properties from the 48-hour multiple-well aquifer tests of Fairfield, Pennsylvania, wells $A D-751$ and $A D-754$ (data from Meisler and Earl, Inc., 1991)

[--, not applicable; MTRL, metarhyolite; MBSL, metabasalt; HRPR, Harpers Formation]

\begin{tabular}{lcccc}
\hline $\begin{array}{c}\text { Source of } \\
\text { estimate }\end{array}$ & $\begin{array}{c}\text { Hydraulic } \\
\text { conductivity } \\
\text { (feet per day) }\end{array}$ & $\begin{array}{c}\text { Transmissivity } \\
\text { (square feet } \\
\text { per day) }\end{array}$ & Storativity & Aquifer \\
\hline AD-751 (pumping) & 0.36 & 150 & -- & MTRL and MBSL \\
AD-754 & .82 & 270 & -- & $\begin{array}{c}\text { HRPR (minor) } \\
\text { MTRL (major) }\end{array}$ \\
AD-755 & 1.5 & 130 & 0.00008 & MTRL \\
& & & & HRPR (minor) \\
AD-754 (pumping) & .28 & 94 & -- & MTRL (major) \\
AD-751 & .24 & 94 & .00048 & MTRL and MBSL \\
AD-755 & .76 & 67 & .00012 & MTRL \\
\hline
\end{tabular}

Table 41. Summary of hydraulic properties from the 48.5- and 49-hour multiple-well aquifer tests of Fairfield, Pennsylvania, wells AD-736 and AD-750 (data from Peffer, 1996)

[--, not applicable; HRPR, Harpers Formation; MTRL, metarhyolite]

\begin{tabular}{lcccc}
\hline Source of estimate & $\begin{array}{c}\text { Hydraulic } \\
\text { conductivity } \\
\text { (feet per day) }\end{array}$ & $\begin{array}{c}\text { Transmissivity } \\
\text { (square feet } \\
\text { per day) }\end{array}$ & Storativity & Aquifer \\
\hline AD-736 (pumping) & 0.028 & $1.0-14$ & -- & HRPR \\
AD-749 & .001 & .5 & 0.000066 & HRPR \\
AD-750 (pumping) & .21 & $66-68$ & -- & HRPR (minor) \\
AD-752 & 1.5 & 500 & .00037 & MTRL (major) \\
\hline
\end{tabular}




\section{$\underline{\text { Recharge and Ground-Water Flow }}$}

The average annual precipitation from 1939 to 1991 in the South Mountain area is $46.38 \mathrm{in}$. (National Oceanic and Atmospheric Administration, 1991); however, only a small part of this precipitation recharges the ground water. Taylor and Royer (1981, p. 4) estimated that ground-water recharge is only $7 \mathrm{in} / \mathrm{yr}$ for Adams County. Gerhart and Lazorchick (1988, table 12) estimated average annual ground-water recharge as ranging from 6.0 to 8.3 in.

The time for recharge to reach the lower bedrock zone is highly variable, ranging from a few hours to possibly years. Nelms and Brockman (1997, figs. 25-27) estimated recharge ages of 030 years for water from wells in Prince William County, Va., that are completed in the same geologic units as the Fairfield well field.

The water table is a subdued reflection of topography (fig. 17). Water-level gradients are steeper on the mountain slopes than in the valley. Topographic highs such as ridges and mountain tops represent ground-water divides. Toms Creek and various minor springs at altitudes above the Fairfield well field, and above the homes north of Toms Creek, represent discharge points for ground water flowing through the upper, highly weathered zone.

The ground-water levels used to draw figure 17 were generally measured in September 1997 while wells AD-751 or AD-754 were actively pumping. Consequently, they represent water levels under stressed conditions. Water levels in public-supply wells AD-751 and AD-754 were measured by airline and represent approximate water levels. Water levels measured in deep wells (table 38) probably represent a composite of the hydraulic head in multiple aquifers penetrated in each well.

Most active ground-water circulation in the Fairfield well field area is probably in the upper, highly weathered zone and, in the area of well AD-754, to a depth of at least $376 \mathrm{ft}$ of the bedrock zone along cleavage planes and bedrock fractures. This natural circulation pattern, however, can be altered by heavy pumping. Peffer Geotechnical Corp. (1996) concluded that pumping of well AD-750 will strongly interfere with wells AD-751 and AD-754 and several domestic wells. This anisotropy is the result of the orientation of cleavage planes in the metarhyolite. Because of this anisotropy, ground-water flow directions are not necessarily perpendicular to lines of equal hydraulic head. In addition, multiple-well aquifer tests (Meisler and Earl, Inc., 1991; Peffer, 1996) indicate (1) infiltration was not induced from Toms Creek, (2) there is only minor interference between wells AD-736 and AD-750, (3) the contact between the metarhyolite and the Harpers Formation is not a major source of water to well AD-754, and (4) hydraulic properties of the Harpers Formation are considerably lower than the metarhyolite or metabasalt.

\section{Piedmont Lowland - Littlestown Well AD-744}

Littlestown well AD-744 (locally known as Production Well A) is just east of Littlestown, Pa., in Union Township (fig. 20). The area around the well is characterized by residential and agricultural land uses. The Conestoga Formation, which underlies the immediate area, is moderately resistant to weathering, forming rolling hills and valleys of limited relief (generally less than $75 \mathrm{ft}$ ). The well is within the Potomac River Basin but near the drainage basin divide with the Susquehanna River Basin (fig. 20). Numerous small springs and sinkholes are present immediately north of the basin divide.

Well AD-744 was reportedly drilled to a depth of $498 \mathrm{ft}$ and cased to $58 \mathrm{ft}$ bls. Water-bearing fractures were penetrated at depths of 12, 47, 171, 185 , and $498 \mathrm{ft}$ bls (table 42). The well is pumped on a continuously rotating schedule with other public supply wells in the Littlestown well system.

\section{Conceptual Ground-Water Flow System Near Well AD-744}

A conceptual diagram of ground-water flow in the vicinity of well AD-744 was developed from published information describing general hydrogeologic conditions of fractured rock having thick regolith and unpublished information from the Littlestown area including drillers' logs (table 42), borehole geophysics, water levels, and aquifer tests. Much of the detailed discussion of hydrogeologic properties presented in this section was based on the results from extensive site characterization work conducted by R.E. Wright Associates, Inc. (1989; 1994a), to develop well AD-744 and several other public supply wells in the area and from a report describing a groundwater flow model of the Lower Susquehanna River Basin in Pennsylvania and Maryland (Gerhart and Lazorchick, 1988). 


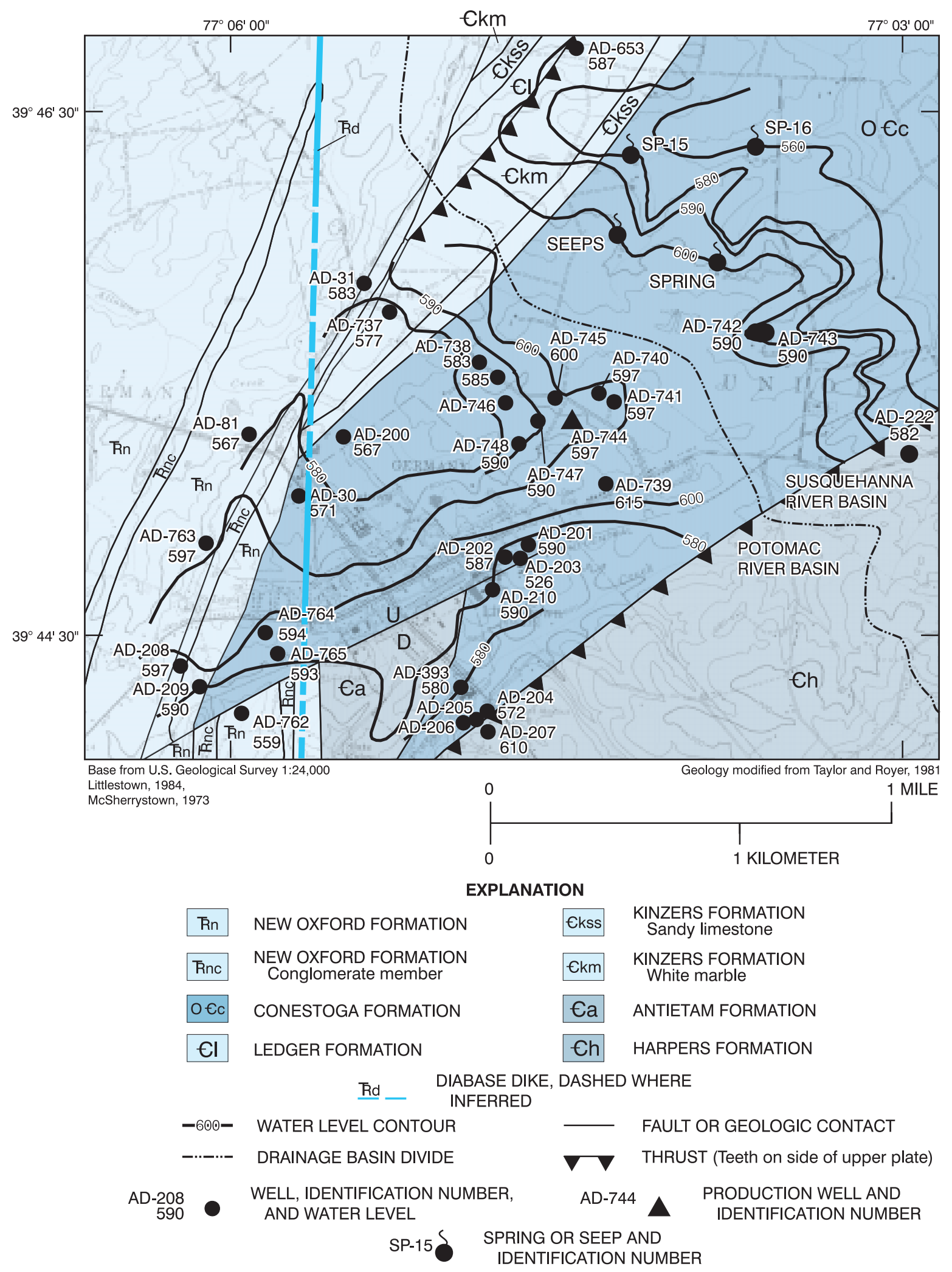

Figure 20. Location of well AD-744, selected other wells, general geology, drainage basin, and water-level contours in the vicinity of Littlestown, Pennsylvania. 
Table 42. Record of selected wells in the vicinity of Littlestown, Pennsylvania

[Location of wells are shown in figure 20. Depth in feet below land surface; gal/min, gallons per minute; (gal $/ \mathrm{min}) / \mathrm{ft}$, gallons per minute per foot of drawdown; --, not available; P, public; U, unused public; D, domestic; X, destroyed public; -, water level above land surface; CNSG, Conestoga Formation; NOXF, New Oxford Formation; HRPR, Harpers Formation; KZRS, Kinzers Formation]

\begin{tabular}{|c|c|c|c|c|c|c|c|c|c|c|}
\hline $\begin{array}{c}\text { Well } \\
\text { number }\end{array}$ & $\begin{array}{l}\text { Well } \\
\text { depth }\end{array}$ & $\begin{array}{l}\text { Casing } \\
\text { length }\end{array}$ & $\begin{array}{l}\text { Reported } \\
\text { yield } \\
\text { (gal/min) }\end{array}$ & $\begin{array}{c}\text { Specific } \\
\text { capacity } \\
{[(\text { gal } / \mathrm{min}) / \mathrm{ft}]}\end{array}$ & $\begin{array}{c}\text { Reported } \\
\text { depth to } \\
\text { water } \\
\text { (ft) }\end{array}$ & $\begin{array}{c}\text { Date water } \\
\text { level } \\
\text { measured }\end{array}$ & $\begin{array}{l}\text { Reported } \\
\text { depth to } \\
\text { water-bearing } \\
\text { zones } \\
\text { (ft) }\end{array}$ & $\begin{array}{l}\text { Water } \\
\text { use }\end{array}$ & $\begin{array}{c}\text { Depth to } \\
\text { bedrock } \\
(\mathrm{ft})\end{array}$ & Aquifer \\
\hline AD-29 & 33 & 33 & -- & -- & 23.1 & $07-29-1960$ & -- & $\mathrm{D}$ & 33 & NOXF \\
\hline AD-30 & 33 & -- & -- & -- & 28.76 & 08-10-1960 & -- & $D$ & -- & CNSG \\
\hline AD-31 & 114 & -- & -- & -- & 41.92 & 08-10-1960 & -- & D & -- & NOXF \\
\hline AD-200 & 400 & 41 & 43 & 0.18 & 8 & 10-00-1965 & 70,280 & $U$ & 10 & CNSG \\
\hline AD-201 & 278 & -- & 40 & -- & 20 & 06-17-1987 & -- & $P$ & -- & CNSG \\
\hline AD-202 & 400 & -- & 60 & -- & 23 & 04-11-1988 & -- & $P$ & -- & CNSG \\
\hline AD-203 & 193 & -- & 60 & -- & -- & -- & -- & $\mathrm{P}$ & -- & CNSG \\
\hline AD-204 & 365 & 100 & 14 & .10 & 28 & 01-21-1988 & -- & $\mathrm{P}$ & -- & CNSG \\
\hline AD-205 & 340 & -- & 30 & -- & -- & -- & -- & $P$ & -- & CNSG \\
\hline AD-206 & 200 & -- & 75 & -- & 25 & -- & -- & $P$ & -- & CNSG \\
\hline AD-207 & 510 & -- & 17 & -- & 30 & 01-22-1988 & -- & $P$ & -- & CNSG \\
\hline AD-208 & 452 & 48 & 12.3 & 1.2 & 21.5 & 08-15-1969 & 310,405 & $P$ & 12 & CNSG \\
\hline AD-209 & 400 & 49 & 63 & .22 & 6 & $12-12-1967$ & 68,170 & $P$ & -- & CNSG \\
\hline AD-222 & 100 & 44 & 12 & -- & 40 & 06-00-1966 & 89 & D & 40 & HRPR \\
\hline AD-653 & 150 & 43 & 45 & -- & 13.24 & 05-20-1993 & $57,82,87,122$ & D & -- & KZRS \\
\hline AD-740 & 114 & -- & 8 & -- & 47.45 & 09-22-1997 & -- & $D$ & -- & CNSG \\
\hline AD-741 & 145 & 20 & 10 & -- & 52.2 & 09-22-1997 & -- & D & -- & CNSG \\
\hline AD-744 & 498 & 58 & 118 & .59 & 3.34 & 02-02-1989 & $\begin{array}{c}12,47,171 \\
185,498\end{array}$ & $P$ & 8 & CNSG \\
\hline AD-745 & 298 & 39 & 38 & .32 & .69 & 03-23-1989 & $108,156,162$ & $P$ & 9 & CNSG \\
\hline AD-746 & 398 & 16 & 25 & -- & Flowing & 02-07-1989 & 276,329 & $x$ & 14 & CNSG \\
\hline AD-747 & 398 & 20 & 3 & -- & -.71 & 02-06-1989 & 398 & $x$ & 43 & CNSG \\
\hline AD-748 & 298 & 20 & 17 & -- & -.9 & 02-09-1989 & $14,98,141,157,193$ & $x$ & 16 & CNSG \\
\hline AD-762 & 745 & 58 & 100 & 1.3 & 10.9 & 10-02-1997 & $\begin{array}{c}38,65,134,214 \\
363,486,651\end{array}$ & $\mathrm{P}$ & 7 & $\begin{array}{l}\text { NOXF/ } \\
\text { CNSG }\end{array}$ \\
\hline AD-763 & 300 & 40 & 253 & 5.0 & 3.3 & $12-15-1992$ & $53,79,97,163,272$ & $\mathrm{P}$ & 10 & NOXF \\
\hline AD-764 & 200 & 51 & 400 & 3.6 & 6 & 07-07-1993 & $37,43,53,89$ & $P$ & 32 & CNSG \\
\hline AD-765 & 200 & 54 & 400 & -- & 7 & 06-23-1993 & 40,60 & $x$ & 26 & CNSG \\
\hline
\end{tabular}

A conceptual diagram of the hydrogeologic framework in the vicinity of well AD-744 is shown in figure 21 and described in the following sections. In general, the framework shows a heterogeneous fractured bedrock aquifer whose upper part is truncated by a zone of regolith and highly weathered bedrock that lies parallel to land surface.

\section{Upper Highly Weathered Zone}

The upper, highly weathered zone consists of 7 to $45 \mathrm{ft}$ or so of soil and clayey or shaly residuum, schist, and broken limestone or phyllite (where saturated). Soil drainage can be poor in areas underlain by abundant clay. Ground water is unconfined to semiconfined, largely dependent on the amount of clay present. This flow system is influenced more strongly by the topography of the land surface and depth of weathering of the bedrock surface than by geologic structure. The upper layer is an important source of ground water to the less weathered lower layer. Hydraulic conductivity may range from 0.01 to $1,000 \mathrm{ft} / \mathrm{d}$, and transmissivity ranges from 0.1 to $5,000 \mathrm{ft}^{2} / \mathrm{d}$ (Dennis J. Low and others, U.S. Geological Survey, written commun., 1998). 


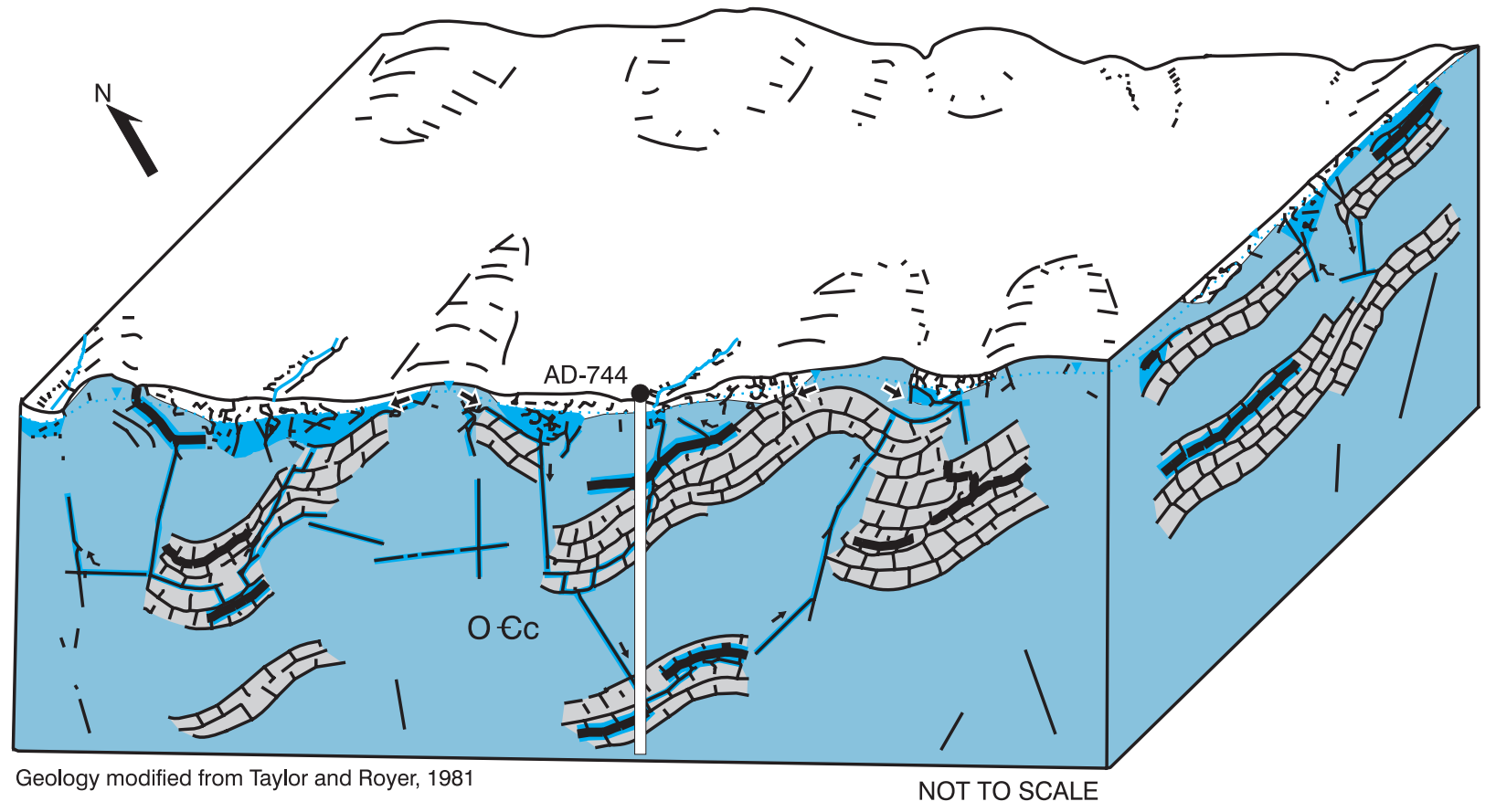

EXPLANATION

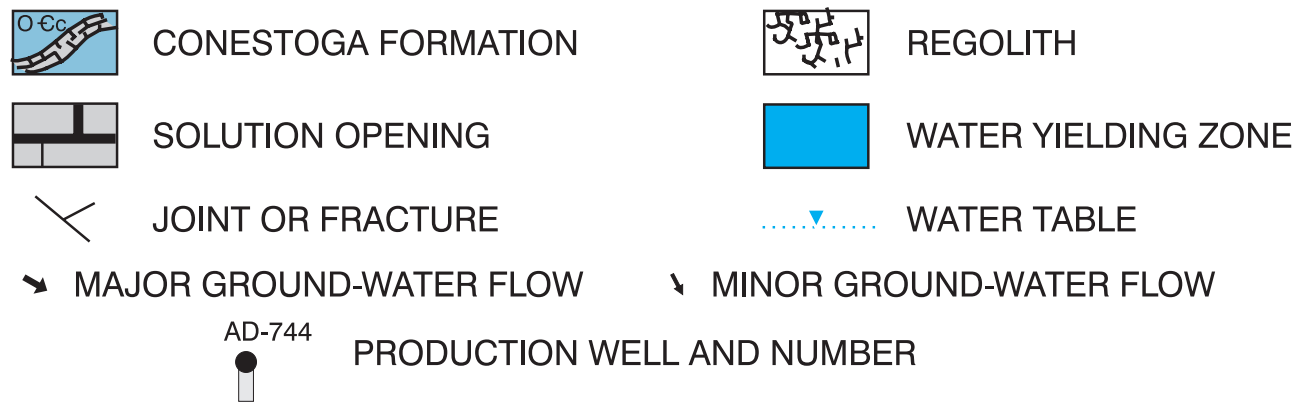

Figure 21. General geology and ground-water flow near Littlestown, Pennsylvania, well AD-744. 


\section{Lower Bedrock Zone}

On the basis of information from table 42 and borehole geophysical logs, the lower bedrock zone consists of about $650 \mathrm{ft}$ or more of competent, but jointed, fractured, and faulted phyllitic to dolomitic limestone that commonly contains shaly partings. The water-bearing zones consist almost entirely of secondary openings in the limestone that may be enlarged by weathering. Drawdown cones defined from the aquifer test of well AD-744 (R.E. Wright Associates, Inc., 1989) indicate these secondary openings are most permeable in a northeast-southwest direction or roughly parallel to the fault between the Antietam and Conestoga Formations just south of the well site (Stose, 1932; Taylor and Royer, 1981). The shale beds, however, are relatively impermeable and represent confining layers. In general, this produces a somewhat layered and anisotropic aquifer that is locally well connected hydraulically (fig. 21).

Despite extensive site characterization by R.E. Wright, borehole geophysical logs were not available from the original suite of wells drilled in the immediate vicinity of well AD-744. To provide additional information on the ground-water flow system of the lower bedrock zone, wells AD-208 and AD-762 were selected for borehole geophysical logging on the basis of availability, the formation(s) penetrated, and well depth.

The caliper log for well AD-208 shows this well was drilled to a depth of $452 \mathrm{ft}$ with a small fracture at $66 \mathrm{ft}$ bls and numerous but minor fractures throughout the borehole (fig. 22). Under nonpumping conditions, the fluid-resistivity log shows a change in slope from 350-430 ft bls, which indicates water is slowly entering the borehole through a number of minor fractures. The naturalgamma and single-point resistance logs indicate numerous shaly beds characteristic of the Conestoga Formation in this area. The fluidtemperature log shows a relatively constant change in slope with two very minor deflections present at 351 and $48 \mathrm{ft}$ bls. The heatpulse flowmeter measured upward flow at 70, 150, 200, $250,290,350$, and $390 \mathrm{ft}$ bls and no flow at $420 \mathrm{ft}$ (table 43). Apparently, most water enters the borehole between 390 and $420 \mathrm{ft}$ bls and again at about $350 \mathrm{ft}$ bls. The water moves upward before exiting the borehole through a minor fracture at about $48 \mathrm{ft}$ bls. The driller's log reported water enters the borehole at 310 and $405 \mathrm{ft}$ bls (table 42). Although no geologic log is available for this well,
Table 43. Summary of heatpulse-flowmeter measurements for Littlestown, Pennsylvania, well $A D-208$

[--, not applicable]

\begin{tabular}{ccc}
\hline $\begin{array}{c}\text { Depth } \\
\text { (feet below } \\
\text { land surface) }\end{array}$ & $\begin{array}{c}\text { Flow rate under } \\
\text { ambient conditions } \\
\text { (gallons per minute) }\end{array}$ & $\begin{array}{c}\text { Flow direction under } \\
\text { ambient conditions }\end{array}$ \\
\hline 70 & 0.12 & $\mathrm{Up}$ \\
150 & .10 & $\mathrm{Up}$ \\
200 & .08 & $\mathrm{Up}$ \\
250 & .10 & $\mathrm{Up}$ \\
290 & .10 & $\mathrm{Up}$ \\
350 & .06 & $\mathrm{Up}$ \\
390 & .07 & $\mathrm{Up}$ \\
420 & no flow & -- \\
\hline
\end{tabular}

the driller's log from well AD-209 indicated the New Oxford Formation was only $49 \mathrm{ft}$ thick and it overlies the Conestoga Formation.

Well AD-762 is the deepest known well in the area of Littlestown and was drilled through the overlying New Oxford Formation into the Conestoga Formation. The caliper log shows this well is $680 \mathrm{ft}$ deep and it is cased with 7.5-in.diameter casing to a depth of $59 \mathrm{ft}$. The driller reported the well was drilled to a total depth of $745 \mathrm{ft}$ and silting apparently took place after a long-term aquifer test. The caliper log shows the presence of major fractures at 64-66, 87, 131-137, 261-263, 647, and $649 \mathrm{ft}$ bls plus minor fractures throughout the openhole interval (fig. 23). At $671 \mathrm{ft}$ bls, the driller changed to a 6-in.-diameter drill bit. Under nonpumping conditions, the fluidresistivity log shows minor deflections at about 656, 430, 400, 370, 340, 260, and $140 \mathrm{ft}$ bls. The natural-gamma and single-point-resistance logs indicate a major change in lithology at $585 \mathrm{ft}$ bls. According to the geologist log, this is the depth at which the sandstone and some siltstone of the New Oxford Formation is in contact with the dolomite and dolomitic limestone of the Conestoga Formation (Peffer Geotechnical Corp., written commun., 1997). The single-point resistivity and natural-gamma logs indicate another change in lithology at $650 \mathrm{ft}$ bls. Here, the geologist log reported the dolomite and dolomitic limestone graded into phyllite and phyllitic limestone. The fluid-temperature log exhibits very little slope from the bottom of the borehole to about $130 \mathrm{ft}$ bls, which indicates vertical borehole flow is present. A minor deflection in the fluid-temperature log also is present at $654 \mathrm{ft}$ bls. The heatpulse flowmeter measured upward flow from 640 to $110 \mathrm{ft}$ bls and 

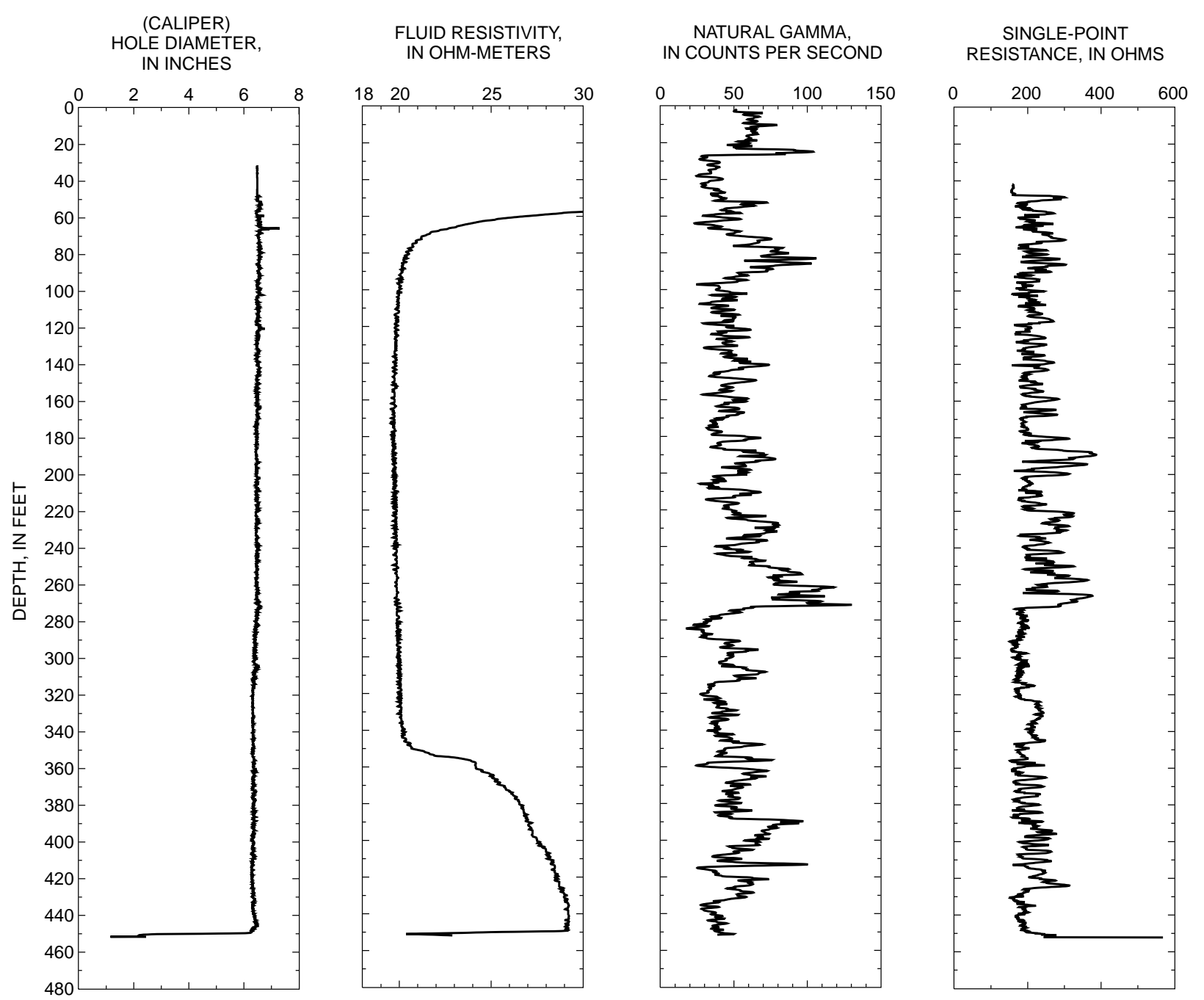

FLUID TEMPERATURE, IN DEGREES CELSIUS

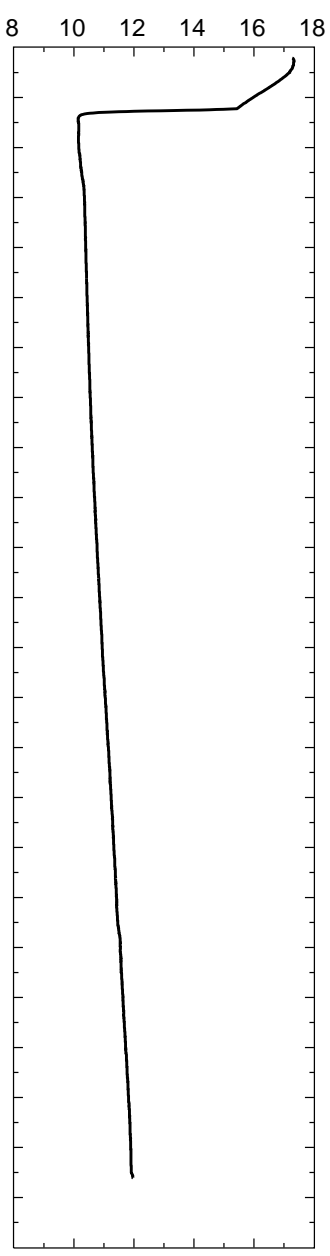

Figure 22. Borehole geophysical logs for borehole AD-208, September 23, 1997. 


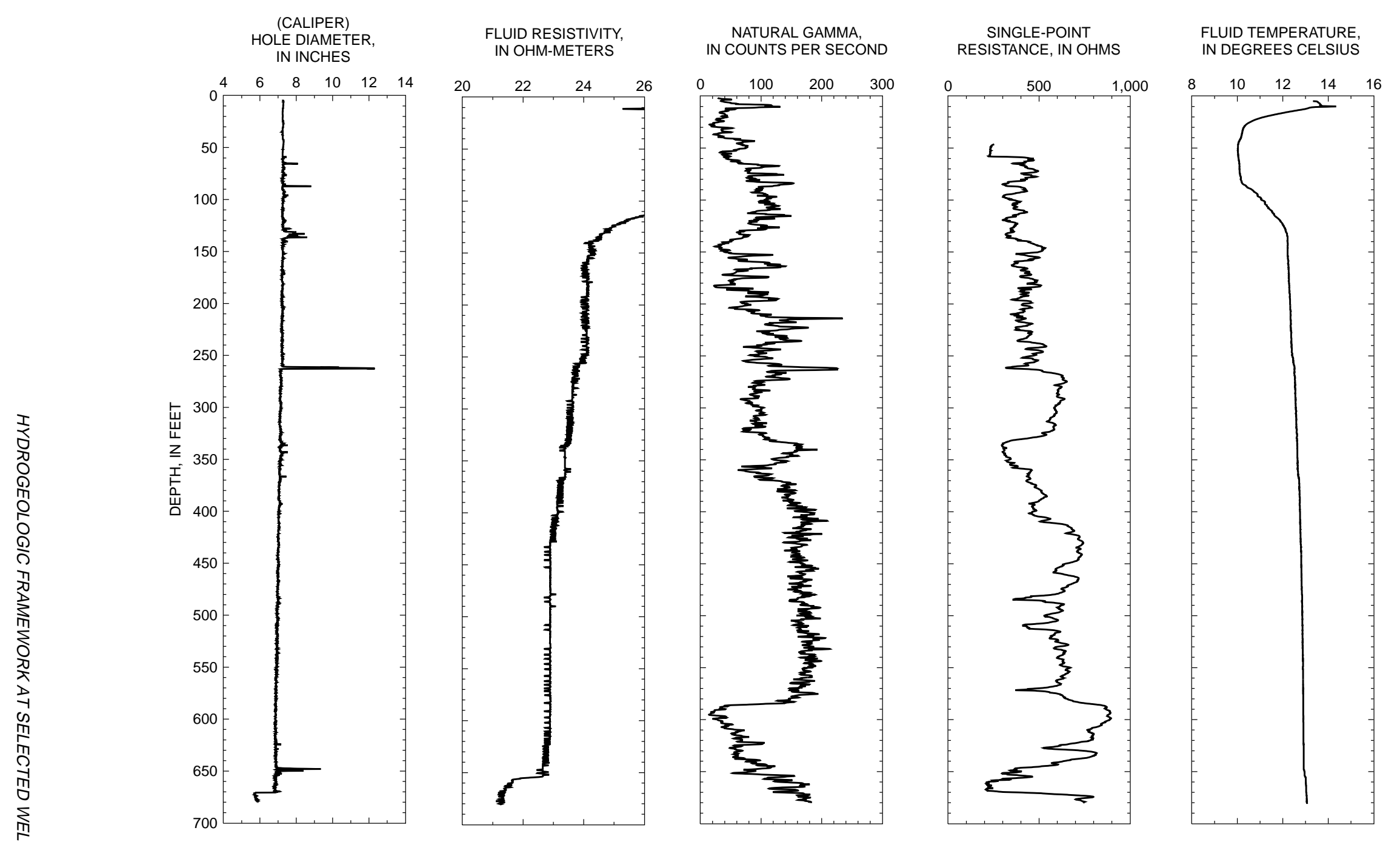

Figure 23. Borehole geophysical logs for borehole AD-762, October 2, 1997. 
downward flow at $72 \mathrm{ft}$ bls (table 44). Apparently, most water in well AD-762 enters the borehole through the major fractures at 649 and $647 \mathrm{ft}$ bls, flows upward, and exits the borehole through the fractures at 128 to $137 \mathrm{ft} \mathrm{bls}$. A minor amount of water continues to flow upward before exiting through the major fracture at $87 \mathrm{ft}$ bls. Water also enters the borehole just below the bottom of casing, flows downward, and exits through the major fracture at $87 \mathrm{ft}$ bls.

R.E. Wright Associates, Inc. (1989), estimated transmissivities of 93 and $122 \mathrm{ft}^{2} / \mathrm{d}$ for wells $\mathrm{AD}-745$ and $\mathrm{AD}-744$, respectively. In the vicinity of wells AD-764 and AD-765, however, transmissivity was estimated to range from 107 to $414 \mathrm{ft}^{2} / \mathrm{d}$ (R.E. Wright Associates, Inc., 1994a). Estimates of hydraulic conductivity and transmissivity can vary considerably in the Conestoga Formation (table 45). Hydraulic conductivities and transmissivities were calculated from 1 hour or longer, specificcapacity tests by use of a modified Theis formula (Theis and others, 1963). A specific yield of 0.03 was used to determine these hydraulic properties. Gerhart and Lazorchick (1988, table 8) estimated an average hydraulic conductivity for their upper layer (0 to $200 \mathrm{ft}$ bls) as $10.03 \mathrm{ft} / \mathrm{d}$.

Under pumping conditions, it is apparent the lower bedrock zone of the Conestoga Formation is anisotropic with respect to hydraulic conductivity. Multiple-well aquifer tests (R.E. Wright Associates, Inc., 1989) of well AD-744 indicated the direction of greatest hydraulic conductivity is northeastsouthwest. Drawdowns of 23 and $40 \mathrm{ft}$ were reported in observation wells AD-740 and AD-741, respectively, located northeast of the pumping well (fig. 20). The only other well showing any response to the step-drawdown and aquifer tests was well AD-745, and drawdown in this well was less than $0.1 \mathrm{ft}$. A step-drawdown test of well AD-745 followed by a 72-hour aquifer test showed very little drawdown (less than $2.1 \mathrm{ft}$ ) was reported from observation wells; no drawdown was evident in wells AD-740 and AD-741.

The effective porosity of the area around well AD-744 is not known. Heath (1983) estimated that limestone may have primary porosity of 10 percent and secondary porosity equally as great. However, the presence of dolomite and shale can greatly reduce the amount of primary and secondary porosity.

Table 44. Summary of heatpulse-flowmeter measurements for Littlestown, Pennsylvania, well $A D-762$

[--, not applicable]

\begin{tabular}{ccc}
\hline $\begin{array}{c}\text { Depth } \\
\text { (feet below } \\
\text { land surface) }\end{array}$ & $\begin{array}{c}\text { Flow rate under } \\
\text { ambient conditions } \\
\text { (gallons per minute) }\end{array}$ & $\begin{array}{c}\text { Flow direction under } \\
\text { ambient conditions }\end{array}$ \\
\hline 72 & 0.38 & Down \\
110 & .14 & $\mathrm{Up}$ \\
150 & 1.0 & $\mathrm{Up}$ \\
250 & 1.3 & $\mathrm{Up}$ \\
300 & 1.2 & $\mathrm{Up}$ \\
350 & 1.0 & $\mathrm{Up}$ \\
450 & 1.2 & $\mathrm{Up}$ \\
550 & 1.2 & $\mathrm{Up}$ \\
600 & 1.1 & $\mathrm{Up}$ \\
640 & 1.2 & $\mathrm{Up}$ \\
660 & no flow & -- \\
\hline
\end{tabular}

Table 45. Hydraulic conductivity and transmissivity from single-well aquifer or specific-capacity tests in the Conestoga Formation throughout Pennsylvania

[Note: Hydraulic conductivity and transmissivity were calculated from specific-capacity tests by the method of Theis and others, 1963 , using a specific yield of $0.03 ; \mathrm{ft} / \mathrm{d}$, feet per day; $\mathrm{ft}^{2} / \mathrm{d}$, feet squared per day]

\begin{tabular}{|c|c|c|c|c|c|c|c|c|}
\hline \multirow{2}{*}{$\begin{array}{l}\text { Hydraulic } \\
\text { property }\end{array}$} & \multirow{2}{*}{$\begin{array}{l}\text { Number } \\
\text { of wells }\end{array}$} & \multicolumn{5}{|c|}{$\begin{array}{l}\text { Percentage of samples in which } \\
\text { value was equaled or exceeded }\end{array}$} & \multirow{2}{*}{ Minimum } & \multirow{2}{*}{ Maximum } \\
\hline & & 90 & 75 & $\begin{array}{c}50 \\
\text { (median) }\end{array}$ & 25 & 10 & & \\
\hline Hydraulic conductivity (ft/d) & 77 & 0.02 & 0.15 & 1.9 & 20 & 49 & 0.00 & 5,400 \\
\hline Transmissivity $\left(\mathrm{ft}^{2} / \mathrm{d}\right)$ & 77 & 5.9 & 40 & 310 & 790 & 5,500 & .40 & 23,000 \\
\hline
\end{tabular}




\section{Recharge and Ground-Water Flow}

The average annual precipitation from 1904 to 1988 at Hanover, Pa., is 40.00 in. (National Oceanic Atmospheric Administration, 1988); however, only a small part of this recharges ground water. Taylor and Royer (1981, p. 4) estimated that ground-water recharge is only $7 \mathrm{in} / \mathrm{yr}$ for the entire county. Gerhart and Lazorchick (1988, table 12) estimated average annual ground-water recharge as ranging from 9.2 to 10.8 in. for the Conestoga Formation just east of Littlestown. R.E. Wright Associates, Inc. (1993b), estimated annual recharge to the Conestoga Formation under normal years as $12.1 \mathrm{in} / \mathrm{yr}$ or $576,000(\mathrm{gal} / \mathrm{d}) / \mathrm{mi}^{2}$ and $6.3 \mathrm{in}$. or $300,000(\mathrm{gal} / \mathrm{d}) / \mathrm{mi}^{2}$ under drought conditions.

The time required to recharge the lower layer with ground water can be measured in hours. During the 72-hour multiple-well aquifer test of well AD-744, two periods of precipitation were reported. The first precipitation event, which measured about 0.75 in., began about 460 minutes after the start of the aquifer test. The second precipitation event, which measured about 0.4 in., began about 1,300 minutes after the start of the aquifer test. The drawdown curve showed the effect of the two recharge events at 720 and 2,300 minutes after the onset of pumping, respectively (R.E. Wright Associates, Inc., 1989, fig. $4)$.

In general, the water table is a subdued reflection of topography. Water levels in topographically high areas generally are a little deeper (further from land surface) than water levels in topographically low areas such as valleys (table 6). In general, most ground-water flow in the lower bedrock zone is upward because of confining or semiconfining conditions. Recharge within each stream basin generally discharges into the adjacent stream valley (Lloyd and Growitz, 1977). Ground-water flow in the Littlestown area, however, also is influenced by hydraulic head differences that are in turn affected by topographic position, pumping of public-supply wells (table 42), and anisotropy.

The ground-water levels used to draw the water-level contours in figure 20 were measured over a period of years from July 1960 through September 1997. Consequently, they represent water levels in different seasons, different climatic conditions, and different pumping conditions. Water levels in public-supply wells were collected when the wells were under construction or undergoing maintenance and were not pumping. Water-level data from several wells in the study area indicate variability in water levels can be about $20 \mathrm{ft}$. Water levels measured in deep wells probably represent a composite of the hydraulic head in multiple aquifers penetrated in each well. In general, the water levels suggest the diabase dike to the east of Littlestown and the numerous faults and formational contacts do not represent ground-water divides. It does appear, however, that the thin, elongate beds of the New Oxford conglomerate have some effect on ground-water flow.

Littlestown and well AD-744 are located near or on several ground-water divides. Heavy pumping of public-supply wells in and around Littlestown will alter the shape and distribution of the water-level contours shown in figure 20 and possibly the apex of the divides. The most important ground-water divide in the Littlestown area is the drainage basin divide between the Susquehanna River Basin and the Potomac River Basin (fig. 20). Aquifer tests and water-level measurements indicate the lower bedrock zone is anisotropic, and under pumping conditions, the drawdown cone for well AD-744 extends towards the drainage basin divide of the Susquehanna River and the Potomac River. With available information, however, it is impossible to determine if the capture zone or drawdown cone for well AD-744 extends eastward into the Susquehanna River Basin.

Most active ground-water circulation in the Littlestown area is probably in the upper, highly weathered zone and the upper several hundred feet or so of the lower bedrock zone. Borehole geophysical logs, however, show ground-water flow is present to depths of $650 \mathrm{ft}$ or greater and most of this flow is upward toward areas of lower hydraulic head. The water at these great depths is confined and probably moves most commonly through near-vertical to vertical fractures and joints that cross bedding planes and are large enough to facilitate rapid movement of water across differing rock layers, thus serving as a major hydraulic connection between bedding-plane fractures (fig. 21). Major low-angle thrust faults, such as the one between the New Oxford and Conestoga Formations, are not water-producing zones. This may be the result of lithostatic pressure or the amount of fault gouge and clays present at the thrust contact. Structural control, however, may affect well AD-744. Aquifer tests indicate 
substantial drawdown in a northeast-southwest direction or roughly parallel to the fault between the Antietam and Conestoga Formations just south of the well site (Stose, 1932; Taylor and Royer, 1981).

\section{SUMMARY}

Rapid population growth in Adams County has increased the demand for ground water. When existing community water systems were evaluated, however, county officials discovered that many water systems were inadequate for the projected population growth. To assist local municipalities with decisions concerning their water resources, the Adams County Office of Planning and Development developed a WaterSupply/Wellhead-Protection plan. The USGS supported this planning effort by summarizing the hydrogeology and water quality of Adams County and describing the hydrogeologic structure of four well fields in differing hydrogeologic units.

In general, ground water is available in sufficient quantities to meet most future needs of a growing population. Results of multiple comparison tests on ranked well yields by water use, hydrogeologic unit, and geologic formation show a significant difference between reported yields from domestic wells in the Gettysburg Lowland and Blue Ridge and those in the Piedmont Lowland and Piedmont Upland. Reported yields of nondomestic wells, however, are not significantly different between hydrogeologic units.

Overall, the Gettysburg Formation is the most productive unit in Adams County, but large yields also are reported from many other geologic formations in the county. Water use has the most significant effect on reported yield. Nondomestic wells generally yield significantly greater amounts of water than domestic wells. Location also affects reported yield, but areal variability is great and no definite pattern was identified. The yields of domestic wells (table 2) completed in the Gettysburg Formation are significantly greater than yields of domestic wells in the New Oxford Formation, diabase, metarhyolite, and metabasalt (Blue Ridge). In the Blue Ridge, reported domestic yields are generally greater from the metarhyolite and lower in the metabasalt; the medians are 8.0 and $5.0 \mathrm{gal} / \mathrm{min}$, respectively. Domestic wells in the limestone of the Vintage Formation in the Piedmont Lowland have the greatest median yields (16 gal $/ \mathrm{min})$ and wells in the Conestoga Formation the lowest yields $(6.0 \mathrm{gal} / \mathrm{min})$. In the Piedmont Upland, domestic wells completed in the Harpers Formation have the greatest median yield $(8.9 \mathrm{gal} / \mathrm{min})$ and the Chickies Formation the lowest $(4.0 \mathrm{gal} / \mathrm{min})$.

Although the total number of wells with specific-capacity data is relatively small, the relations between specific capacity and hydrogeologic unit or geologic formation are similar to those for well yields. The median specific capacity of domestic wells in the Gettysburg Lowland and Piedmont Lowland are 0.14 and 0.11 (gal $/ \mathrm{min}) / \mathrm{ft}$, respectively. These are lower than the median specific capacities of $0.24(\mathrm{gal} / \mathrm{min}) / \mathrm{ft}$ for domestic wells in the Blue Ridge and 0.15 (gal $/ \mathrm{min}) / \mathrm{ft}$ in the Piedmont Upland. Results of multiple comparison tests on ranked specific-capacity data indicate that the nondomestic wells in the Conestoga Formation have significantly greater specific capacities than nondomestic wells in the Gettysburg and New Oxford Formations, diabase, and metarhyolite (table 3). Domestic wells, however, exhibit no significant differences between hydrogeologic units or geologic formations.

The intended use of the well (water use) is the most important factor in determining well depth. Nondomestic wells are generally drilled to significantly greater depths than domestic wells. Domestic wells drilled in the Blue Ridge are generally deeper than domestic wells in the other three hydrogeologic units. For nondomestic wells, however, well depths are generally greatest in the Piedmont Lowland (table 4).

Water levels are most commonly affected by topography, geologic structure, and discharge areas (springs or pumping wells), as well as the number and depths of water-bearing fractures penetrated. Median water levels (table 5) from domestic wells are shallowest in the Gettysburg Lowland $(22 \mathrm{ft})$ and greatest in the Piedmont Upland (33 ft).

Overburden thickness varies by hydrogeologic unit and geologic formation. The overburden above the diabase and the New Oxford Formation in the Gettysburg Lowland and the carbonate rocks of the Piedmont Lowland are relatively thin. Overburden thickness is generally greatest in the more resistant rocks of the Blue Ridge (table 7). 
In general, the water quality in Adams County is good and acceptable for most uses. Elevated concentrations of sulfate, iron, and magnesium are the most common water-quality problems. Nutrients, pesticides, herbicides, VOC's, and radionuclides have been reported in the ground water at concentrations that exceed USEPA MCL's at a few isolated locations. The small sample population, however, prevents any detailed assessment of these undesirable constituents.

The hydrogeologic framework in the vicinity of four well sites located in the Gettysburg Lowland, Blue Ridge, and Piedmont Lowland hydrogeologic units is complex and consists of an upper, highly weathered zone and a lower bedrock zone. The upper, highly weathered zone is relatively thin, with a maximum thickness of about 50 to $60 \mathrm{ft}$. Ground-water flow in the lower bedrock zone is generally confined with active flow measured as deep as $650 \mathrm{ft}$ bls. Relatively impermeable shales are present at the well sites in the Gettysburg Lowland and Piedmont Lowland. These shales limit the amount of water that can move vertically to the pumping well and are responsible for the anisotropy in the Gettysburg Lowland. In the Blue Ridge, cleavage is believed responsible for the anisotropy; faults do not appear to be highly transmissive. Drawdowns at the four well sites are extensive. Drawdown cones migrate rapidly from the pumping wells, are generally narrow, elongate parallel to strike, cleavage planes, or structural features, and have affected other public or domestic wells.

\section{SELECTED REFERENCES}

Ator, S.W., and Ferrari, M.J., 1997, Nitrate and selected pesticides in ground water of the MidAtlantic Region: U.S. Geological Survey Water-Resources Investigations Report 974139, 8 p.

Ator, S.W., Blomquist, J.D., Brakebill, J.W., Denis, J.M., Ferrari, M.J., Miller, C.V., and Zappia, Humbert, 1998, Water quality in the Potomac River Basin, Maryland, Pennsylvania, Virginia, West Virginia, and the District of Columbia, 1992-96: U.S. Geological Survey Circular 1166, $38 \mathrm{p}$.
Babcock, C.A., Luckey, R.R., Morgan, C.O., and Stephens, D.M., 1992, Ground-water site inventory coding instructions, in National Water Information System user's manual, v. 2, chap. 4, Ground-Water Site Inventory system: U.S. Geological Survey Open-File Report 89-587, p. 7-126.

Becher, A.E., 1989, Geohydrology and water quality in the vicinity of the Gettysburg National Military Park and Eisenhower National Historic Site, Pennsylvania: U.S. Geological Survey Water-Resources Investigations Report 89-4154, $44 \mathrm{p}$.

Becher, A.E., and Taylor, L.E., 1982, Groundwater resources in the Cumberland and contiguous valleys of Franklin County, Pennsylvania: Pennsylvania Topographic and Geologic Survey, 4 th ser., $67 \mathrm{p}$.

Bennett, G.D., and Patten, E.P., Jr., 1960, Borehole geophysical methods for analyzing specific capacity of multiaquifer wells: U.S. Geological Survey Water-Supply Paper 1536-A, 25 p.

Berg, T.M., Barnes, J.H., Sevon, W.D., Skema, V.W., Wilshusen, J.P., and Yannacci, D.W., 1989, Physiographic provinces of Pennsylvania: Pennsylvania Geological Survey, 4th ser., map 13, 1 sheet, 1:2,000,000.

Berg, T.M., Edmunds, W.E., Geyer, A.R., Glover, A.D., Hoskins, D.M., MacLachlan, D.B., Root, S.I., Sevon, W.D., and Socolow, A.A., comps., 1980, Geologic map of Pennsylvania: Pennsylvania Topographic and Geologic Survey, 4th ser., scale 1:250,000, 2 sheets.

Bickford, T.M., Lindsey, B.D., and Beaver, M.R., 1996, Bacteriological quality of ground water used for household supply, Lower Susquehanna River Basin, Pennsylvania and Maryland: U.S. Geological Survey WaterResources Investigations Report 96-4212, 31 p.

Chow, T.J., and Earl, J.L., 1970, Lead aerosols in the atmosphere-increasing concentrations: Science, v. 169, p. 577-580.

Clark, G.M., 1991, South Mountain geomorphology, in Faill, R.T., and Sevon, W.D., eds., 1994, Various aspects of Piedmont geology in Lancaster and Chester Counties, Pennsylvania: Annual Field Conference of Pennsylvania Geologists, 59th, Lancaster, Pa., Guidebook, p. 55-94. 
Cook, J.M., and Miles, D.L., 1980, Methods for the chemical analysis of ground water: Great Britain Institute Geological Sciences, Report $80-15,55 \mathrm{p}$.

Cooper, H.H., Jr., and Jacob, C.E., 1946, A generalized graphical method of evaluating formation constants and summarizing wellfield history: American Geophysical Union Transactions, v. 27, no. 4, p. 526-534.

Cummings/Riter Consultants, Inc., 1997, Final design report, Gettysburg Elevator Plant site, Adams County, Pennsylvania: Pittsburgh, Pa., Cummings/Riter Consultants, Inc. [variously paged].

Driscoll, F.G., 1986, Groundwater and wells (2d ed.): St. Paul, Minn., Johnson Division, $1,089 \mathrm{p}$.

Dugas, D.L., and Weisbeker, N.J., 1997, Assessment and evaluation of hydrogeologic conditions, Adams County, Pennsylvania [online]: U.S. Geological Survey Open-File Report 97-244, available from World Wide Web http://pa.water.usgs.gov/.

Durfor, C.N., and Becker, Edith, 1964, Public water supplies of the 100 largest cities in the U.S., 1962: U.S. Geological Survey Water-Supply Paper 1812, $364 \mathrm{p}$.

Durum, W.H., Hem, J.D., and Heidel, S.G., 1971, Reconnaissance of selected minor elements in surface waters of the U.S., October, 1970: U.S. Geological Survey Circular 643, 49 p.

Fauth, J.L., 1968, Geology of the Caledonia Park quadrangle area, South Mountain, Pennsylvania: Pennsylvania Topographic and Geologic Survey, 4th ser., Atlas 129a, 133 p.

1978, Geology and mineral resources of the Iron Springs area, Adams and Franklin Counties, Pennsylvania: Pennsylvania Topographic and Geologic Survey, 4th ser., Atlas $129 \mathrm{c}, 72 \mathrm{p}$.

Fenneman, N.M., 1938, Physiography of Eastern United States: New York, McGraw-Hill Book Company, Inc., 691 p.

Gerhart, J.M., and Lazorchick, G.J., 1984, Evaluation of the ground-water resources of parts of Lancaster and Berks Counties, Pennsylvania: U.S. Geological Survey WaterResources Investigations Report 84-4327, $136 \mathrm{p}$.
1988, Evaluation of the ground-water resources of the Lower Susquehanna River Basin, Pennsylvania and Maryland: U.S. Geological Survey Water- Supply Paper 2284, $128 \mathrm{p}$.

Gohn, G.S., 1976, Sedimentology, stratigraphy, and paleogeography of lower Paleozoic carbonate rocks, Conestoga Valley, southeastern

Pennsylvania: Ph.D. dissertation, University of Delaware, $314 \mathrm{p}$.

Hartwig, N.L., Gesell, S.G., and Dum, S.A., 1980, Pesticide use survey for agronomic crops in Pennsylvania: State College, Pa., Pennsylvania State University, $36 \mathrm{p}$.

Heath, R.C., 1983, Basic ground-water hydrology: U.S. Geological Survey WaterSupply Paper 2220, 84 p.

1984, Ground-water regions of the United States: U.S. Geological Survey Water-Supply Paper 2242, $78 \mathrm{p}$.

Helsel, D.R., and Hirsch, R.M., 1992, Statistical methods in water resources: Amsterdam, Netherlands, Elsevier Science Publishers, Studies in environmental science \#49, $522 \mathrm{p}$.

Hem, J.D., 1985, Study and interpretation of the chemical characteristics of natural water: U.S. Geological Survey Water-Supply Paper 2254, $263 \mathrm{p}$.

Johnston, H.E., 1966, Hydrology of the New Oxford Formation in Lancaster County, Pennsylvania: Pennsylvania Topographic and Geologic Survey, 4th ser., Ground Water Report W 23, 80 p.

Keys, W.S., 1990, Borehole geophysics applied to ground-water investigations: U.S. Geological Survey Techniques of Water-Resources Investigations, book 2, chap. E-2, 149 p.

Knopman, D.S. 1990, Factors related to the wateryielding potential of rocks in the Piedmont and Valley and Ridge Provinces of Pennsylvania: U.S. Geological Survey Water-Resources Investigations Report 90-4174, 52 p.

Langland, M.J., and Dugas, D.L., 1995, Assessment of severity and distribution of corrosive ground water in Pennsylvania: U.S. Geological Survey Open-File Report 95-377, 2 map sheets. 
Langland, M.J., and Fishel, D.K., 1996, Effects of agricultural best-management practices on the Brush Run Creek Headwaters, Adams County, Pennsylvania, prior to and during nutrient management: U.S. Geological Survey WaterResources Investigations Report 95-4195, 80 p.

Lewis-Brown, J.C., and Jacobsen, Eric, 1995, Hydrogeology and ground-water flow, fractured Mesozoic structural basin rocks, Stony Brook, Beden Brook, and Jacobs Creek Drainage Basins, west-central New Jersey: U.S. Geological Survey Water-Resources Investigations Report 94-4147, 83 p.

Lindsey, B.D., and Ator, S.W., 1996, Radon in ground water of the Lower Susquehanna and Potomac River Basins: U.S. Geological Survey Water-Resources Investigations Report 964156, 6 p.

Lindsey, B.D., Breen, K.J., Bilger, M.D., and Brightbill, R.A., 1998, Water quality in the Lower Susquehanna River Basin, Pennsylvania and Maryland, 1992-95: U.S. Geological Survey Circular 1168, 38 p.

Lloyd, O.B., Jr., and Growitz, D.J., 1977, Groundwater resources of central and southern York County, Pennsylvania: Pennsylvania Topographic and Geologic Survey, 4th ser., Water Resource Report 42, 93 p.

Meisler and Earl, Inc., 1991, Fairfield Municipal Authority, assessment of sustained well yields and aquifer hydraulic properties, Hamiltonban Township, Adams County, Pennsylvania: State College, Pa., Meiser and Earl, Inc. [variously paged].

Meisler, Harold, and Becher, A.E., 1971, Hydrogeology of the carbonate rocks of the Lancaster 15-minute quadrangle, southeastern Pennsylvania: Pennsylvania Topographic and Geologic Survey, 4th ser., Water Resource Report 26, 149 p.

Meyer, Gerald, and Beall, R.M., 1958, The water resources of Carroll and Frederick Counties [Maryland]: Maryland Department of Geology, Mines and Water Resources Bulletin 22, $355 \mathrm{p}$.

Michalski, Andrew, and Britton, Richard, 1997, The role of bedding fractures in the hydrogeology of sedimentary bedrock-evidence from the Newark Basin, New Jersey: Ground Water, vol. 35, no. 2, p. 318-327.
Morin, R.H., Carleton, G.B., and Poirier, S., 1997, Fractured-aquifer hydrogeology from geophysical logs; the Passaic Formation, New Jersey: Ground Water, vol. 35, no. 2, p. 328338.

National Oceanic and Atmospheric Administration, 1988, Climatological data annual summary, Pennsylvania: U.S. Department of Commerce, v. 93, no. 13.

1991, Climatological data annual summary, Pennsylvania: U.S. Department of Commerce, v. 96, no. 13.

1993, Climatological data annual summary, Pennsylvania: U.S. Department of Commerce, v. 98 , no. 13.

Nelms, D.L., and Brockman, A.R., 1997, Hydrogeology of, and quality and recharge ages of ground water in, Prince William County, Virginia, 1990-91: U.S. Geological Survey Water-Resources Investigations Report 97-4009, 58 p.

Norman Day Associates, 1991, Comprehensive Plan, Adams County, Pennsylvania: Prepared by Norman Day Associates for the Adams County Planning Commission [variously paged].

Nowell, L.H., and Resek, E.A., 1994, Summary of national standards and guidelines for pesticides in water, bed sediment, and aquatic organisms and their application to waterquality assessments: U.S. Geological Survey Open-File Report 94-44, 115 p.

Papadopulos, I.S., and Cooper, H.H., Jr., 1967, Drawdown in a well of large diameter: U.S. Geological Survey Water-Resources Research, v. 3, no. 1, p. 241-244.

Patten, E.P., Jr., and Bennett, G.D., 1962, Methods of flow measurement in well bores: U.S. Geological Survey Water-Supply Paper 1544C, $28 \mathrm{p}$.

Peffer Geotechnical Corp., Jeff, 1996, A report on the pumping tests of potential source wells T9 and T10 for the community public water supply of the Fairfield Municipal Authority, Hamiltonban Township, Adams County, Pennsylvania: Lewisberry, Pa., Peffer Geotechnical Corp. [variously paged]. 
Pennsylvania Department of Environmental

Resources, 1980, State Water Plan - 8, Subbasin 7, Lower Susquehanna River: Harrisburg, Pa., Office of Resources Management, Bureau of Resources Programming, $294 \mathrm{p}$.

1979, State Water Plan - 14, Subbasin 13, Potomac River: Harrisburg, Pa., Office of Resources Management, Bureau of Resources Programming, $119 \mathrm{p}$.

Petura, J.C., 1980, TCE in ground water-a problem assessment: The Weston Way, v. 6, no. 2.

Reed, J.L., 1980, Type curves for selected problems of flow to wells in confined aquifers: U.S. Geological Survey Techniques of WaterResource Investigations, book 3, chap. B3, $106 \mathrm{p}$.

R.E. Wright Associates, Inc., 1982, Special groundwater study of the Middle Delaware River Basin - Study Area II: Middletown, Pa., R.E. Wright Associates, Inc. [variously paged].

1989, Groundwater development, Meadowview Estates, Littlestown, Pennsylvania: Middletown, Pa., R.E. Wright Associates, Inc. [variously paged].

1993a, Potential impact of gasoline spill on Borough of Abbottstown Water Authority well PW-6: Middletown, Pa., R.E. Wright Associates, Inc. [variously paged].

1993b, Groundwater development for the proposed Appler subdivision, Littlestown, Pennsylvania: Middletown, Pa., R.E. Wright Associates, Inc. [variously paged].

1994a, Groundwater development for the proposed Briarwood Estates subdivision, Littlestown, Pennsylvania: Middletown, Pa., R.E. Wright Associates, Inc. [variously paged].

1994b, Evaluation of the impact of a gasoline release on Abbottstown production well 6 and of spill site remediation activities:

Middletown, Pa., R.E. Wright Associates, Inc. [variously paged].

Risser, D.W., and Barton, G.J., 1995, A strategy for delineating the area of ground-water contribution to wells completed in fractured bedrock aquifers in Pennsylvania: U.S. Geological Survey Water-Resources Investigations Report 95-4033, $30 \mathrm{p}$.
Rizzo Associates, Inc., 1991, Remedial Investigation/Feasibility study, Westinghouse Plant site, Cumberland Township, Adams County, Pennsylvania: Monroeville, Pa., Paul C. Rizzo Associates, Inc. [variously paged].

Robinove, C.J., Langford, R.H., and Brookhart, J.W., 1958, Saline-water resources of North Dakota: U.S. Geological Survey Water-Supply Paper 1428, 72 p.

Schreffler, C.L., 1996, Hydrogeologic framework of the diabase aquifer at the Boarhead Farms Superfund site, Bridgeton Township, Bucks County, Pennsylvania: U.S. Geological Survey Water-Resources Investigations Report 964090, 58 p.

Sloto, R.A., 1994, Geology, hydrology, and groundwater quality of Chester County, Pennsylvania: West Chester, Pa., Chester County Water Resources Authority WaterResource Report 2, 127 p.

Sloto, R.A., and Davis, D.K., 1983, Effect of urbanization on the water resources of Warminister Township, Bucks County, Pennsylvania: U.S. Geological Survey Water Resources Investigation 82-4020, $72 \mathrm{p}$.

Sloto, R.A., and McManus, B.C., 1996, Hydrogeology and ground-water quality of Valley Forge National Historical Park, Montgomery County, Pennsylvania: U.S. Geological Survey Water-Resources Investigations Report 96-4120, 35 p.

Stose, G.W., 1932, Geology and mineral resources of Adams County, Pennsylvania: Pennsylvania Topographic and Geologic Survey, 4th ser., Bulletin C 1, 153 p.

Stose, G.W., and Bascom, Florence, 1929, Description of the Fairfield and Gettysburg quadrangles [Pennsylvania]: U.S. Geological Survey Geologic Atlas, Folio 225, 22 p.

Stose, G.W., and Jonas, A.I., 1939, Geology and mineral resources of York County Pennsylvania: Pennsylvania Topographic and Geologic Survey, 4th ser., Bulletin C 67, 199 p.

Taylor, L.E., and Royer, D.W., 1981, Summary groundwater resources of Adams County, Pennsylvania: Pennsylvania Topographic and Geologic Survey, 4th ser., Water Resources Report 52, 50 p. 
Tetrault, R.C., and Wuest, P.J., 1979, Pennsylvania grower's guide to mushroom pest control: University Park, Pa., Cooperative Extension Service, Pennsylvania State University.

Theis, C.V., 1940, The source of water derived from wells, essential factors controlling the response of an aquifer to development: Civil Engineering, v. 10, no. 5, p. 277-280.

Theis, C.V., Brown, R.H., and Meyer, R.R., 1963, Estimating the transmissibility of aquifers from the specific capacity of wells, in Bental, R., ed., Methods of determining permeability, transmissibility, and drawdown: U.S. Geological Survey Water-Supply Paper 1536-I, p. 331-340.

U.S. Environmental Protection Agency, 1991, Maximum contaminant level goals and primary drinking water regulations for lead and copper, Final Rule: U.S. Code of Federal Regulations, Title 40.

1992, A citizen's guide to radon: U.S. Environmental Protection Agency report 402K92-001, May 1992, 15 p.
1996, Drinking water regulations and health advisories: Washington, D.C., EPA 822-R-96$00117 \mathrm{p}$.

U.S. Geological Survey, 1986, National Water Summary 1986 -- Hydrologic events and ground-water quality: U.S. Geological Survey Water-Supply Paper 2325, $560 \mathrm{p}$.

Waller, R.M., 1989, Ground water and the rural homeowner: U.S. Geological Survey General Interest Publication, $37 \mathrm{p}$.

Wood, C.R., 1980, Groundwater resources of the Gettysburg and Hammer Creek Formations, Southeastern Pennsylvania: Pennsylvania Topographic and Geologic Survey, 4th ser., Water Resource Report 49, 87 p.

Wood, P.R. and Johnston, H.E., 1964, Hydrology of the New Oxford Formation in Adams and York Counties, Pennsylvania: Pennsylvania Topographic and Geologic Survey, 4th ser., Water Resource Report 21, 66 p.

Zapecza, O.S., and Szabo, Z., 1988, Natural radioactivity in ground water-a review: U.S. Geological Survey Water-Supply Paper 2325, p. 50-57. 
APPENDIX A.-Pesticides sampled in ground water, Adams County, Pennsylvania

$[<$, less than $]$

\begin{tabular}{|c|c|c|c|c|c|}
\hline $\begin{array}{l}\text { Laboratory } \\
\text { parameter code }\end{array}$ & $\begin{array}{c}\text { Compound } \\
\text { (parameter name) }\end{array}$ & $\begin{array}{l}\text { Number of } \\
\text { wells } \\
\text { sampled }\end{array}$ & $\begin{array}{l}\text { Number of } \\
\text { wells in which } \\
\text { compound } \\
\text { was detected }\end{array}$ & $\begin{array}{c}\text { Minimum } \\
\text { concentration } \\
\text { in micrograms } \\
\text { per liter }\end{array}$ & $\begin{array}{c}\text { Maximum } \\
\text { concentration } \\
\text { in micrograms } \\
\text { per liter }\end{array}$ \\
\hline P49295 & 1-Naphthol, filtered & 5 & 0 & $<0.007$ & $<0.05$ \\
\hline P39082 & 1,2-Dibromoethylene & 8 & 0 & $<.2$ & $<.2$ \\
\hline P82183 & 2, 4-DP, total & 12 & 0 & $<.01$ & $<.01$ \\
\hline P39730 & $2,4-\mathrm{D}$, total & 12 & 1 & $<.01$ & .01 \\
\hline P39732 & 2,4-D, dissolved & 5 & 0 & $<.035$ & $<.05$ \\
\hline P38746 & 2,4-DB, filtered & 5 & 0 & $<.035$ & $<.05$ \\
\hline P39742 & 2,4,5-T, dissolved & 5 & 0 & $<.035$ & $<.05$ \\
\hline P39740 & $2,4,5-\mathrm{T}$, total & 12 & 0 & $<.01$ & $<.01$ \\
\hline P82660 & 2,6-Diethylaniline, filtered & 5 & 0 & $<.003$ & $<.006$ \\
\hline P49308 & 3-Hydroxycarbofuran, filtered & 5 & 0 & $<.014$ & $<.05$ \\
\hline P49315 & Acifluorfen, filtered & 5 & 0 & $<.035$ & $<.05$ \\
\hline P46342 & Alachlor, dissolved, recoverable & 5 & 0 & $<.002$ & $<.009$ \\
\hline P77825 & Alachlor, total, recoverable & 11 & 0 & $<.1$ & $<.1$ \\
\hline P49312 & Aldicarb, filtered & 5 & 0 & $<.016$ & $<.05$ \\
\hline P49313 & Aldicarb sulfone, filtered & 5 & 0 & $<.016$ & $<.05$ \\
\hline P49314 & Aldicarb sulfoxide, filtered & 5 & 0 & $<.021$ & $<.05$ \\
\hline P39053 & Aldicarb, total & 1 & 0 & $<.5$ & $<.5$ \\
\hline P39330 & Aldrin, total & 11 & 0 & $<.01$ & $<.01$ \\
\hline P34253 & Alpha BHC & 5 & 0 & $<.002$ & $<.007$ \\
\hline P82184 & Ametryne, total & 18 & 0 & $<.1$ & $<.1$ \\
\hline P39630 & Atrazine, unfiltered, recoverable & 18 & 1 & $<.1$ & .1 \\
\hline P39632 & Atrazine, dissolved, recoverable & 5 & 2 & $<.001$ & $<.017$ \\
\hline P82673 & Benfluralin, filtered & 5 & 0 & $<.002$ & $<.013$ \\
\hline P38711 & Bentazon, filtered & 5 & 0 & $<.014$ & $<.05$ \\
\hline P04029 & Bromacil, dissolved, recoverable & 5 & 0 & $<.035$ & $<.05$ \\
\hline P49311 & Bromoxynil, filtered & 5 & 0 & $<.035$ & $<.05$ \\
\hline P04028 & Butylate, dissolved, recoverable & 5 & 0 & $<.002$ & $<.008$ \\
\hline P82680 & Carbaryl, filtered & 5 & 0 & $<.003$ & $<.046$ \\
\hline P49310 & Carbaryl, filtered & 5 & 0 & $<.008$ & $<.05$ \\
\hline P39750 & Carbaryl, unfiltered, recoverable & 3 & 0 & $<2$ & $<2$ \\
\hline P81405 & Carbofuran & 1 & 0 & $<.5$ & $<.5$ \\
\hline P82674 & Carbofuran, filtered & 5 & 0 & $<.003$ & $<.013$ \\
\hline P49309 & Carbofuran, filtered & 5 & 0 & $<.028$ & $<.05$ \\
\hline P49307 & Chloramben, filtered & 5 & 0 & $<.011$ & $<.05$ \\
\hline P39350 & Chlordane, total & 11 & 0 & $<.1$ & $<.1$ \\
\hline P49306 & Chlorothalonil, filtered & 5 & 0 & $<.035$ & $<.05$ \\
\hline P38933 & Chlorpyrifos, dissolved & 5 & 0 & $<.004$ & $<.005$ \\
\hline P49305 & Clopyralid, filtered & 5 & 0 & $<.05$ & $<.05$ \\
\hline P81757 & Cyanazine, total & 18 & 0 & $<.1$ & $<.1$ \\
\hline P04041 & Cyanazine, dissolved, recoverable & 5 & 0 & $<.004$ & $<.013$ \\
\hline P49304 & Dacthal, mono-acid, filtered & 5 & 0 & $<.017$ & $<.05$ \\
\hline P82682 & DCPA, filtered & 5 & 0 & $<.002$ & $<.004$ \\
\hline P39365 & $\mathrm{P}, \mathrm{P}^{\prime}-\mathrm{DDE}$, total & 11 & 0 & $<.01$ & $<.01$ \\
\hline P04040 & Deethyl atrazine, dissolved & 3 & 0 & $<.002$ & $<.02$ \\
\hline P39572 & Diazinon, dissolved & 5 & 0 & $<.002$ & $<.008$ \\
\hline P39570 & Diazinon, total & 11 & 2 & $<.01$ & .01 \\
\hline P38442 & Dicamba, filtered & 5 & 0 & $<.035$ & $<.05$ \\
\hline
\end{tabular}


APPENDIX A.—Pesticides sampled in ground water, Adams County, Pennsylvania—Continued

\begin{tabular}{|c|c|c|c|c|c|}
\hline $\begin{array}{l}\text { Laboratory } \\
\text { parameter code }\end{array}$ & $\begin{array}{c}\text { Compound } \\
\text { (parameter name) }\end{array}$ & $\begin{array}{l}\text { Number of } \\
\text { wells } \\
\text { sampled }\end{array}$ & $\begin{array}{l}\text { Number of } \\
\text { wells in which } \\
\text { compound } \\
\text { was detected }\end{array}$ & $\begin{array}{c}\text { Minimum } \\
\text { concentration } \\
\text { in micrograms } \\
\text { per liter }\end{array}$ & $\begin{array}{c}\text { Maximum } \\
\text { concentration } \\
\text { in micrograms } \\
\text { per liter }\end{array}$ \\
\hline P82052 & Dicamba, total & 12 & 1 & $<0.01$ & 0.03 \\
\hline P49303 & Dichlobenil, filtered & 5 & 0 & $<.02$ & $<.05$ \\
\hline P49302 & Dichlorprop, filtered & 5 & 0 & $<.032$ & $<.05$ \\
\hline P39381 & Dieldrin, dissolved & 5 & 0 & $<.001$ & $<.02$ \\
\hline P39380 & Dieldrin, total & 11 & 0 & $<.01$ & $<.01$ \\
\hline P82662 & Dimethoate, filtered & 1 & 0 & $<.02$ & $<.02$ \\
\hline P49301 & Dinoseb, filtered & 5 & 0 & $<.035$ & $<.05$ \\
\hline P82677 & Disulfoton, filtered & 5 & 0 & $<.017$ & $<.02$ \\
\hline P49300 & Diuron, filtered & 5 & 0 & $<.02$ & $<.05$ \\
\hline P49299 & DNOC, filtered & 5 & 0 & $<.035$ & $<.05$ \\
\hline P39388 & Endosulfan I, total & 11 & 0 & $<.01$ & $<.01$ \\
\hline P39390 & Endrin, unfiltered, recoverable & 11 & 0 & $<.01$ & $<.01$ \\
\hline P82668 & EPTC, filtered & 5 & 0 & $<.002$ & $<.005$ \\
\hline P49298 & Esfenvalerate, filtered & 5 & 0 & $<.019$ & $<.05$ \\
\hline P39786 & Trithion, total & 11 & 0 & $<.01$ & $<.01$ \\
\hline P82663 & Ethalfluralin, filtered & 5 & 0 & $<.004$ & $<.013$ \\
\hline P39398 & Ethion, total & 11 & 0 & $<.01$ & $<.01$ \\
\hline P82672 & Ethoprop, filtered & 5 & 0 & $<.003$ & $<.012$ \\
\hline P49297 & Fenuron, filtered & 5 & 0 & $<.013$ & $<.05$ \\
\hline P38811 & Fluometuron, filtered & 5 & 0 & $<.035$ & $<.05$ \\
\hline P04095 & Fonofox, dissolved, recoverable & 5 & 0 & $<.003$ & $<.008$ \\
\hline P39420 & Heptachlor epoxide, total & 11 & 0 & $<.01$ & $<.01$ \\
\hline P39410 & Heptachlor, total & 11 & 0 & $<.01$ & $<.01$ \\
\hline P39341 & Lindane, dissolved & 5 & 0 & $<.004$ & $<.011$ \\
\hline P39340 & Lindane, total & 11 & 0 & $<.01$ & $<.01$ \\
\hline P82666 & Linuron, filtered & 5 & 0 & $<.002$ & $<.039$ \\
\hline P38478 & Linuron, filtered & 5 & 0 & $<.018$ & $<.05$ \\
\hline P39532 & Malathion, dissolved & 5 & 0 & $<.005$ & $<.01$ \\
\hline P39530 & Malathion, total & 11 & 1 & $<.01$ & .01 \\
\hline P38487 & $\mathrm{MCP}$, filtered & 5 & 0 & $<.035$ & $<.05$ \\
\hline P38482 & MCPA, filtered & 5 & 0 & $<.05$ & $<.05$ \\
\hline P39600 & Methyl parthion, total & 11 & 0 & $<0.01$ & $<.01$ \\
\hline P39790 & Methyl trithion, total & 11 & 0 & $<.01$ & $<.01$ \\
\hline P38501 & Methiocarb, filtered & 5 & 0 & $<.026$ & $<.05$ \\
\hline P49296 & Methomyl, filtered & 5 & 0 & $<.017$ & $<.05$ \\
\hline P39051 & Methomyl, total & 3 & 0 & $<2$ & $<2$ \\
\hline P39480 & Methoxychlor, total & 11 & 0 & $<.01$ & $<.01$ \\
\hline P82686 & Methyl azinphos, filtered & 5 & 0 & $<.001$ & $<.038$ \\
\hline P82667 & Methyl parathion, filtered & 5 & 0 & $<.006$ & $<.035$ \\
\hline P82612 & Metolachlor, whole, total, recoverable & 15 & 0 & $<.1$ & $<.1$ \\
\hline P39415 & Metolachlor, dissolved & 5 & 0 & $<.002$ & $<.009$ \\
\hline P82611 & Metribuzin, whole, total, recoverable & 8 & 0 & $<.1$ & $<.1$ \\
\hline P82630 & Metribuzin, dissolved & 5 & 0 & $<.004$ & $<.012$ \\
\hline P39755 & Mirex, total & 11 & 0 & $<.01$ & $<.01$ \\
\hline P82671 & Molinate, filtered & 5 & 0 & $<.004$ & $<.007$ \\
\hline P82684 & Napropamide, filtered & 5 & 0 & $<.003$ & $<.01$ \\
\hline P49294 & Neburon, filtered & 5 & 0 & $<.015$ & $<.05$ \\
\hline
\end{tabular}


APPENDIX A.—Pesticides sampled in ground water, Adams County, Pennsylvania—Continued

\begin{tabular}{|c|c|c|c|c|c|}
\hline $\begin{array}{l}\text { Laboratory } \\
\text { parameter code }\end{array}$ & $\begin{array}{c}\text { Compound } \\
\text { (parameter name) }\end{array}$ & $\begin{array}{l}\text { Number of } \\
\text { wells } \\
\text { sampled }\end{array}$ & $\begin{array}{l}\text { Number of } \\
\text { wells in which } \\
\text { compound } \\
\text { was detected }\end{array}$ & $\begin{array}{c}\text { Minimum } \\
\text { concentration } \\
\text { in micrograms } \\
\text { per liter }\end{array}$ & $\begin{array}{c}\text { Maximum } \\
\text { concentration } \\
\text { in micrograms } \\
\text { per liter }\end{array}$ \\
\hline P49293 & Norflurazon, filtered & 5 & 0 & $<0.024$ & $<0.05$ \\
\hline P49292 & Oryzalin, filtered & 5 & 0 & $<.019$ & $<.05$ \\
\hline P38866 & Oxamyl, filtered & 5 & 0 & $<.018$ & $<.05$ \\
\hline P34653 & $\mathrm{P}, \mathrm{P}^{\prime} \mathrm{DDE}$, dissolved & 5 & 0 & $<.006$ & $<.01$ \\
\hline P39360 & $\mathrm{P}, \mathrm{P}^{\prime}-\mathrm{DDD}$, unfiltered, recoverable & 11 & 0 & $<.01$ & $<.01$ \\
\hline P39370 & $\mathrm{P}, \mathrm{P}^{\prime}$-DDT, unfiltered, recoverable & 11 & 0 & $<.01$ & $<.01$ \\
\hline P39542 & Parathion, dissolved & 5 & 0 & $<.004$ & $<.022$ \\
\hline P39540 & Parathion, total & 11 & 0 & $<.01$ & $<.01$ \\
\hline P82669 & Pebulate, filtered & 5 & 0 & $<.004$ & $<.009$ \\
\hline P82683 & Pendimethalin, filtered & 5 & 0 & $<.004$ & $<.018$ \\
\hline P82687 & Permethrin, filtered & 5 & 0 & $<.005$ & $<.016$ \\
\hline P39034 & Perthane, total & 11 & 0 & $<.1$ & $<.1$ \\
\hline P82664 & Phorate, filtered & 5 & 0 & $<.002$ & $<.02$ \\
\hline P39023 & Phorate, total & 1 & 0 & $<.01$ & $<.01$ \\
\hline P49291 & Picloram, filtered & 5 & 0 & $<.05$ & $<.05$ \\
\hline P39720 & Picloram, unfiltered, recoverable & 12 & 1 & $<.01$ & .01 \\
\hline P04037 & Prometon, dissolved, recoverable & 5 & 0 & $<.008$ & $<.018$ \\
\hline P39056 & Prometone, total & 18 & 1 & $<.1$ & .2 \\
\hline P39057 & Prometryne, total & 18 & 0 & $<.1$ & $<.1$ \\
\hline P82676 & Pronamide, filtered & 5 & 0 & $<.003$ & $<.009$ \\
\hline P04024 & Propachlor, dissolved, recoverable & 5 & 0 & $<.007$ & $<.015$ \\
\hline P82679 & Propanil, filtered & 5 & 0 & $<.004$ & $<.016$ \\
\hline P82685 & Propargite, filtered & 5 & 0 & $<.01$ & $<.013$ \\
\hline P39024 & Propazine, total & 18 & 0 & $<.1$ & $<.1$ \\
\hline P49236 & Propham, filtered & 5 & 0 & $<.035$ & $<.05$ \\
\hline P39052 & Propham, total & 3 & 0 & $<2$ & $<2$ \\
\hline P38538 & Propoxur, filtered & 5 & 0 & $<.035$ & $<.05$ \\
\hline P39762 & Silvex, dissolved & 5 & 0 & $<.021$ & $<.05$ \\
\hline P39760 & Silvex, total & 12 & 1 & $<.01$ & .01 \\
\hline P04035 & Simazine, dissolved, recoverable & 5 & 1 & $<.005$ & $<.01$ \\
\hline P39055 & Simazine, total & 18 & 0 & $<.1$ & $<.1$ \\
\hline P39054 & Simetryne, total & 18 & 0 & $<.1$ & $<.1$ \\
\hline P82670 & Tebuthiuron, filtered & 5 & 0 & $<.01$ & $<.015$ \\
\hline P82665 & Terbacil, filtered & 5 & 0 & $<.007$ & $<.03$ \\
\hline P82675 & Terbufos, filtered & 5 & 0 & $<.012$ & $<.013$ \\
\hline P82681 & Thiobencarb, filtered & 5 & 0 & $<.002$ & $<.008$ \\
\hline P39400 & Toxaphene, total & 11 & 0 & $<1$ & $<1$ \\
\hline P82678 & Triallate, filtered & 5 & 0 & $<.001$ & $<.008$ \\
\hline P49235 & Triclopyr, filtered & 5 & 0 & $<.05$ & $<.05$ \\
\hline P82661 & Trifluralin, filtered & 5 & 0 & $<.002$ & $<.012$ \\
\hline P39030 & Trifluralin, total, recoverable & 8 & 0 & $<.1$ & $<.1$ \\
\hline
\end{tabular}


APPENDIX B._-Volatile organic compounds sampled in ground water, Adams County, Pennsylvania

$[<$, less than $]$

\begin{tabular}{|c|c|c|c|c|c|}
\hline $\begin{array}{l}\text { Laboratory } \\
\text { parameter code }\end{array}$ & $\begin{array}{c}\text { Compound } \\
\text { (parameter name) }\end{array}$ & $\begin{array}{l}\text { Number of } \\
\text { wells } \\
\text { sampled }\end{array}$ & $\begin{array}{c}\text { Number of } \\
\text { wells in which } \\
\text { compound was } \\
\text { detected }\end{array}$ & $\begin{array}{c}\text { Minimum } \\
\text { concentration } \\
\text { in micrograms } \\
\text { per liter }\end{array}$ & $\begin{array}{c}\text { Maximum } \\
\text { concentration } \\
\text { in micrograms } \\
\text { per liter }\end{array}$ \\
\hline P77168 & 1,1-Dichloropropene & 5 & 0 & $<0.2$ & $<100$ \\
\hline P34506 & 1,1,1-Trichloroethane & 13 & 3 & $<.2$ & 1,600 \\
\hline P77562 & 1,1,1,2-Tetrachloro-ethane & 5 & 0 & $<.2$ & $<100$ \\
\hline P34511 & 1,1,2-Trichloroethane & 13 & 0 & $<.2$ & $<100$ \\
\hline P34516 & 1,1,2,2-Tetrachloro-ethane & 13 & 0 & $<.2$ & $<100$ \\
\hline P77651 & 1,2-Dibromoethane & 5 & 0 & $<.2$ & $<100$ \\
\hline P32103 & 1,2-Dichloroethane & 13 & 0 & $<.2$ & $<100$ \\
\hline P34546 & 1,2-Transdichloroethene & 13 & 0 & $<.2$ & $<100$ \\
\hline P77613 & 1,2,3-Trichloro benzene & 5 & 0 & $<.2$ & $<100$ \\
\hline P77443 & 1,2,3-Trichlropropane & 5 & 0 & $<.2$ & $<100$ \\
\hline P77222 & 1,2,4-Trimethyl-benzene & 5 & 0 & $<.2$ & $<100$ \\
\hline P34551 & 1,2,4-Trichloro-benzene & 5 & 0 & $<.2$ & $<100$ \\
\hline P34566 & 1,3-Dichloro-benzene & 13 & 0 & $<.2$ & $<100$ \\
\hline P77173 & 1,3-Dichloro-propane & 5 & 0 & $<.2$ & $<100$ \\
\hline P77226 & 1,3,5-Trimethyl-benzen & 5 & 0 & $<.2$ & $<100$ \\
\hline P34571 & 1,4-Dichloro-benzene & 13 & 0 & $<.2$ & $<100$ \\
\hline P77170 & 2,2-Dichloropropane & 5 & 0 & $<.2$ & $<100$ \\
\hline P34210 & Acrolein & 3 & 0 & $<20$ & $<10,000$ \\
\hline P34215 & Acrylonitrile & 3 & 0 & $<20$ & $<10,000$ \\
\hline P34030 & Benzene & 13 & 1 & $<.2$ & $<100$ \\
\hline P81555 & Bromobenzene & 5 & 0 & $<.2$ & $<100$ \\
\hline P77297 & Bromochloro-methane & 5 & 0 & $<.2$ & $<100$ \\
\hline P32104 & Bromoform & 13 & 0 & $<.2$ & $<100$ \\
\hline P32102 & Carbontetrachloride & 13 & 0 & $<.2$ & $<100$ \\
\hline P34576 & Chloroethylvinyl ether & 12 & 0 & $<.2$ & $<500$ \\
\hline P34301 & Chlorobenzene & 13 & 1 & $<.2$ & $<100$ \\
\hline P32105 & Chlorodibromomethane & 13 & 0 & $<.2$ & $<100$ \\
\hline P34311 & Chloroethane & 13 & 0 & $<.2$ & $<100$ \\
\hline P32106 & Chloroform & 13 & 4 & $<.2$ & $<100$ \\
\hline P77093 & Cis-1,2-dichloroethene & 5 & 2 & $<.2$ & 1,200 \\
\hline P34704 & Cis-1,3-dichloropropene & 13 & 0 & $<.2$ & $<100$ \\
\hline P82625 & Dibromochloropropane & 5 & 0 & $<1$ & $<500$ \\
\hline P30217 & Dibromomethane & 5 & 0 & $<.2$ & $<100$ \\
\hline P34668 & Dichlorodifluoromethane & 13 & 0 & $<.2$ & $<100$ \\
\hline P32101 & Dichlorobromomethane & 13 & 0 & $<.2$ & $<100$ \\
\hline P34541 & Dichloropropane & 13 & 0 & $<.2$ & $<100$ \\
\hline P34561 & Dichloropropene & 8 & 0 & $<.2$ & $<.2$ \\
\hline P34371 & Ethylbenzene & 13 & 0 & $<.2$ & $<100$ \\
\hline P77652 & Freon 113 & 5 & 0 & $<.2$ & $<100$ \\
\hline P39702 & Hexachlorobutadiene & 5 & 0 & $<.2$ & $<100$ \\
\hline
\end{tabular}


APPENDIX B.—Volatile organic compounds sampled in ground water, Adams County, Pennsylvania—Continued

\begin{tabular}{|c|c|c|c|c|c|}
\hline $\begin{array}{c}\text { Laboratory } \\
\text { parameter code }\end{array}$ & $\begin{array}{c}\text { Compound } \\
\text { (parameter name) }\end{array}$ & $\begin{array}{l}\text { Number of } \\
\text { wells } \\
\text { sampled }\end{array}$ & $\begin{array}{c}\text { Number of } \\
\text { wells in which } \\
\text { compound was } \\
\text { detected }\end{array}$ & $\begin{array}{c}\text { Minimum } \\
\text { concentration in } \\
\text { micrograms per } \\
\text { liter }\end{array}$ & $\begin{array}{c}\text { Maximum } \\
\text { concentration } \\
\text { in micrograms } \\
\text { per liter }\end{array}$ \\
\hline P77223 & Isopropyl-benzene & 5 & 0 & $<0.2$ & $<100$ \\
\hline P34413 & Methylbromide & 13 & 0 & $<.2$ & $<100$ \\
\hline P34418 & Methylchloride & 13 & 0 & $<.2$ & $<100$ \\
\hline P34423 & Methylenechloride & 13 & 0 & $<.2$ & $<100$ \\
\hline P78032 & Methyl tertiary-butyle ether (MTBE) & 5 & 1 & $<.2$ & $<100$ \\
\hline P77342 & N-butyl-benzene & 5 & 0 & $<.2$ & $<100$ \\
\hline P77224 & N-propyl-benzene & 5 & 0 & $<.2$ & $<100$ \\
\hline P34696 & Naphthalene & 5 & 0 & $<.2$ & $<100$ \\
\hline P77275 & O-chlorotoluene & 5 & 0 & $<.2$ & $<100$ \\
\hline P34536 & O-dichloro-benzene & 13 & 0 & $<.2$ & $<100$ \\
\hline P77277 & P-chloro-toluene & 5 & 0 & $<.2$ & $<100$ \\
\hline P77356 & P-isopropyltoluene & 5 & 0 & $<.2$ & $<100$ \\
\hline P77350 & Sec-butyl-benzene & 5 & 0 & $<.2$ & $<100$ \\
\hline P77128 & Styrene & 13 & 0 & $<.2$ & $<100$ \\
\hline P77353 & Tert-butyl-benzene & 5 & 0 & $<.2$ & $<100$ \\
\hline P34475 & Tetrachloroethylene & 13 & 2 & $<.2$ & $<100$ \\
\hline P34010 & Toluene & 13 & 1 & $<.2$ & $<100$ \\
\hline P34699 & Trans-1,3-dichl.propene & 13 & 0 & $<.2$ & $<100$ \\
\hline P34488 & Trichlorofluoromethane & 13 & 0 & $<.2$ & $<100$ \\
\hline P39180 & Trichloroethylene & 12 & 5 & $<.2$ & 13,000 \\
\hline P39175 & Vinylchloride & 13 & 0 & $<.2$ & $<100$ \\
\hline P81551 & Xylene & 8 & 0 & $<.2$ & $<100$ \\
\hline
\end{tabular}

